\title{
A review on the recent research progress in the compound parabolic concentrator (CPC) for solar energy applications
}

\author{
Meng TIAN ${ }^{1}$, Yuehong $\mathrm{SU}^{1, *}$, Hongfei ZHENG ${ }^{2}$, Gang PEI ${ }^{3}$, Guiqiang $\mathrm{LI}^{3}$, Saffa RIFFAT ${ }^{1}$ \\ ${ }^{1}$ Institute of Sustainable Energy Technology, Department of Architecture and Built Environment, \\ University of Nottingham, University Park, Nottingham NG7 2RD, UK \\ ${ }^{2}$ School of Mechanical Engineering, Beijing Institute of Technology, Beijing 100081, China \\ ${ }^{3}$ Department of Thermal Science and Energy Engineering, University of Science and Technology \\ of China, Hefei, Anhui 230026, China \\ *Corresponding author: yuehong.su@nottingham.ac.uk
}

\begin{abstract}
Compound parabolic concentrator (CPC) has been gaining ever-increasing attention from academic researchers and industrial developers owing to its stationary feature for solar energy collection with a higher efficiency. As a low concentration concentrator with a larger acceptance angle and without a tracking requirement, it is an attractive solution to improve the system performance and reduce the cost of photovoltaic (PV) system, solar thermal system, daylighting and lighting systems, etc. This study will present a comprehensive and up-to-date review of its design principles for miscellaneous configurations, applications, performance predictions and technological advances. Numerous technically focused studies since 2000 will be introduced and summarized. Finally, the outlook focusing on CPC designs and improvements will be proposed.
\end{abstract}

Key words: Compound parabolic concentrator; CPC; Solar energy; Concentration ratio; dielectric. 


\section{Introduction}

Imaging and nonimaging are two broad categories of solar concentrators. In the study of nonimaging optics, the original nonimaging concentrator is a straight cone concentrator which is one of the first 3D concentrator systems [1]. The compound parabolic concentrator (CPC) comes from the development and optimization of cone concentrator during which the theoretical concentration ratio was desired to be the maximum.

The compound parabolic concentrator (CPC) belonging to nonimaging optics is regarded as a highly potential and appealing option for solar energy concentration and illumination since mid1960s [2-9]. It is well known that the principle and geometry of two-dimensional (2D) CPC was firstly described by Winston [10] in 1974. Afterwards, Winston and Hinterberger [11], and Rabl and Winston [12] put forward further explanations in detail. Since then, the term "CPC" has become generic for the whole family of similar devices. In the early stage of CPC design, the applications of three-dimensional (3D) CPC were discussed in terms of infrared collection [13] and retinal structure [14-16].

With the development of CPC in the past fifty years, it has been mainly and widely applied in solar energy like photovoltaic (PV) and solar thermal system as a significant component. The basic of CPC is still as the same as it was designed at the beginning, but researchers have spared no effort to investigate its optic performance and applications in much more disciplines in these years. The rest of applications are in quite various areas, such as gas sensing system [17], wireless communication system [18], infrared temperature sensor system[19], solar thermal water splitting system [20], sky radiator[21], photodiode [22], lasers [23] [24], LED projector[25] [26] [27], terahertz technology [28] [29] and overmoded waveguide [30]; CPC does not play critical roles in these applications usually. In the aspect of solar energy, there are a lot of review articles on CPV/CPVT technology [31-35] and solar thermal technology [35-40] that refer to CPC as one of the practical solution in those areas. However, it's still hard to find a review that is solely dedicated to discussing the basics and advances of the CPC studies appearing in recent years. This paper aims to summarize the CPC studies focusing on solar energy applications since 2000, and to review CPC as comprehensive as possible to contribute to the ongoing efforts to fundamentally understand, design, build, and demonstrate CPC.

The review will begin from the concept, design principles and considerations of CPC in Section 2. In Section 3, an exhaustive coverage of all CPC studies in the literature will be demonstrated according to four main application areas. Then the software applied for simulating CPC performance will be compared and discussed in Section 4. Finally, the future outlook and research directions for CPC studies from early works up till state-of-the-art advances will be presented in Section 5.

\section{Fundamentals and Considerations in CPC Design}

\subsection{Design principles of CPC}

According to Snell's law, Fermat's principle and ray tracing method, the design process of CPC can be described as follows with the reference to Fig. 1, which is called 'edge-ray principle' or the 'string' method [41-43]: In the meridian section of a 3D CPC, assuming all of the rays entering at the extreme collecting angle $\theta_{c}$ shall emerge through the rim point $\mathrm{P}^{\prime}$ of the exit aperture, the parabolic curve with its axis parallel to the direction $\theta_{c}$ and its focus at $\mathrm{P}^{\prime}$ will be derived as one branch of the reflector shape; The complete CPC concentrator in 3D geometry is then obtained by rotating the parabola about the concentrator axis (not the axis of the parabola). If the diameter of the exit aperture is $2 a^{\prime}$ and the maximum allowable incidence angle is $\theta_{c}$, and the overall length $L$ is:

The diameter of the entry aperture is

$$
L=\left(a+a^{\prime}\right) \cot \theta_{c}
$$

$$
a=a^{\prime} / \sin \theta_{c}
$$

The geometrical concentration ratio is a critical parameter in the design of nonimaging optics which is defined as the ratio of the aperture area relative to the receiver's area. The theoretical concentration ratio of CPC in 2D geometry is shown in Eq. (3) [44, 45], which implies that CPC 
becomes close to being an ideal concentrator [44]. 'Ideal' means all of the rays inside the maximum collection angle will not be reflected back and emerge from the exit aperture. In addition, the meridian section of CPC in 2D space is actually ideal and has the maximum theoretical concentration ratio. The principles of designing $2 \mathrm{D} \mathrm{CPC}$ are also provided in several U.S. patents [46-48].

$$
C=a / a^{\prime}=1 / \sin \theta_{c}
$$

If taking the centre of the exit aperture as an origin for Cartesian coordinates and taking z-axis along the concentrator axis as shown in Fig. 1, the equation of the meridian section of a CPC can be expressed as Eq. (4) [44] where the diameter of exit aperture is $2 a^{\prime}$ and the acceptance angle (maximum allowable incidence angle) is $\theta_{c}$. As the CPC surface is obtained by revolving a parabolic curve about the z-axis, this surface can be described by Eq. (4) with $r^{2}=x^{2}+y^{2}$. Winston [44] also presented the surface equations derived from the polar equation of the parabola and azimuthal angle. Another study [49] provides a novel method to calculate the maximum concentration of CPCs in direction cosine space on a polar plane.

$$
\begin{gathered}
\left(r \cos \theta_{c}+z \sin \theta_{c}\right)^{2}+2 a^{\prime}\left(1+\sin \theta_{c}\right)^{2} r-2 a^{\prime} \cos \theta_{c}\left(2+\sin \theta_{c}\right)^{2} z \\
-a^{\prime 2}\left(1+\sin \theta_{c}\right)\left(3+\sin \theta_{c}\right)=0
\end{gathered}
$$

\subsection{Design considerations in structure}

\subsubsection{D and 3D CPC}

Generally, CPC can be roughly classified into two categories which are two-dimensional (2D) and three-dimensional (3D). The $2 \mathrm{D} \mathrm{CPC}$ refers to the CPC that has a longitudinal axis as shown in Fig. 2 a). It can also be called linear CPC or trough-like CPC for some special cases. 3D CPC (Fig. 2 b)) represents the CPC whose geometry is obtained by rotating a $2 \mathrm{D}$ meridian section of CPC at an angular interval. CPCs can be symmetric or asymmetric. The one with four parabolic surfaces and square apertures are called crossed CPC (CCPC) or orthogonal CPC. With the consideration of different geometrical translations, the optical performance of various 3D CPCs were investigated by many researchers. For example, Timinger et al. [50] investigated the optimization of faceted CPCs with discretization of the curvature in both the circumferential and axial directions; van dijk, et al. [51] simulated the relationship between transmittance and concentration ratio (C) of circular, square and hexagonal concentrators with reflectance (R) of $95 \%$ as shown in Fig. 3, which illustrates that the more sides of CPCs apertures has, the closer of optical performance approaches to ideal transmittance; The study by Cooper, T. et al. [52] also implies similar results, in which the optical properties of CPCs with polygonal apertures having $3,4,5,6,8,12$ sides and circular aperture were compared.

\subsubsection{Dielectric filled CPC (dCPC)}

The dielectric CPC is filled with a dielectric material, which is used to enlarge the acceptance angle of a CPC for the same geometry. The dielectric filled 2D and 3D CPCs with total internal reflection were put forward by Winston [54]. The acceptance angle $\theta^{\prime}{ }_{c}$ inside the dielectric and the acceptance angle $\theta_{c}$ of dCPC are shown in Fig. 4 (a). According to the law of refraction, if the refractive index of the dielectric is $n$, the maximum values of both internal and external acceptance angles that can be designed under total internal reflection conditions at certain refractive indices are shown in Fig. 4 (b). In addition, there will be a small enhancement on the angular acceptance of the dielectric-filled 2D CPC for nonmeridional rays [44].

Therefore, the maximum theoretical concentration ratio of dCPCs can be expressed as Eq. (5) where $\theta_{c}$ is the acceptance angle inside the dielectric and the refractive index of air is assumed as 1. It is clearly to see that the concentration ratio increases by the factor $n$ or $n^{2}$ comparing with reflective CPC.

$$
C=n / \sin \theta_{c}(\text { for trough } C P C) \quad \text { or } \quad C=n^{2} / \sin ^{2} \theta_{c}(\text { for } 3 D C P C) \text { (5) }
$$

According to Snell's law (Eq. 6), for the rays whose incidences are larger than the acceptance angle of dCPC, whether they exiting dCPC from parabolic surfaces depends on that whether their incident angles on the dielectric-air interface in dielectric are larger or smaller than the critical angle. In addition, for the rays that have smaller incidences, it is possible for them to get turned back due to total internal reflection.

$$
\theta_{\text {crit }}=\sin ^{-1}\left(n_{2} / n_{1}\right)
$$


where $\theta_{\text {crit }}$ is the critical angle, $n_{1}$ is the higher refractive index and $n_{2}$ is the lower refractive index.

\subsubsection{Truncation of CPC}

As a concentrator that is close to the ideal design, the geometry of CPC is very practical in real application, but the only weakness is that it is very long comparing with its diameter of the collecting aperture which should be considered in large-scale application for the purpose of economic and light weight. Because the parts close to the entrance aperture of the CPC are nearly parallel the optical axis which does not affect the size of entrance aperture too much, CPC can be 'truncated' well short of full development. The effects of truncated length on the sizes of apertures of 2D and 3D CPCs were investigated by Winston and Hinterberger [11], Rabl [56], and Welford and Winston [55] in detail. As a rule of thumb, truncating half of the fully CPC height leads to a good tradeoff between concentration and mirror area [41].

\subsubsection{CPC in special shape}

\subsubsection{Asymmetric CPC}

The 2D and 3D CPCs are symmetric in the original design with two equal half acceptance angles around the symmetry. However, the evolution in the design of a CPC has led to asymmetric CPC for some special purposes. The asymmetric CPC was introduced by Rabl [57] who also pointed out that the ordinary CPC is a special limiting case of the asymmetric CPC. Fig. 5 demonstrates an example of asymmetric ideal concentrator with the acceptance angle of $2 \theta_{c}=\varphi_{l}+\varphi_{r}$ and the geometric concentration ratio of $C=1 / \sin \theta_{c}$. The effective concentration ratio changes with the incident angle [57]. The axis of the left (right) parabola subtends an angle $\varphi_{l}\left(\varphi_{r}\right)$ with the normal of absorber and $F_{l}\left(F_{r}\right)$ is the focus of the left (right) parabola. In practical application, asymmetric CPC is mostly utilized in vertical facade which will be introduced in the following section in detail.

\subsubsection{Sea shell}

The "Sea shell" is another special case of a general asymmetric CPC as shown in Fig. 6. It constitutes a single parabola $C D$ whose axis is parallel to one of the extreme rays. The focus of the parabola is at the edge $A$ of the absorber. It is used to concentrate all incident rays through the aperture $A D$ with the incident angle $|\theta|<\theta_{c}$ (apart from the usual $\cos \theta$ factor for nonnormal incidence).

\subsubsection{CPC with convex absorber}

Winston and Hinterberger [11] proposed that the absorber of ideal concentrator can be not only flat and parallel to the aperture, but also convex. When the absorber is straight, the concentrator includes parabolic and circular sections. Fig. 7 demonstrates two examples of ideal cylindrical concentrators for different absorbers. The shape of reflectors depends on the shape of absorber. For example, in Fig. 7 (a), $A D$ and $A F$ are convolutes of sections $A C$ and $A B$ of absorber; in Fig. 7 (b), sections $D^{\prime}$ and $D^{\prime} E$ belongs to different parabolas. Study [58] provides the calculations of determining the shape of reflector. This kind of design is popular in solar thermal application because it use absorber material more efficiently and there are no losses through the back [57].

\subsubsection{Lens-walled CPC}

Lens-walled CPC can be considered as a combination of reflective CPC with a thin CPC-shape lens, or particular dielectric CPC. As shown in Fig. 8 a), the conventional lens-walled CPC [59-61] is designed by rotating the parabola of symmetric CPC around the end point C (D) of aperture toward the inside by a certain degree. The formed cavity is filled with dielectric to form the CPCshape lens. The outside surface of the lens is layered with a reflective coating. Fig. 8 b) demonstrates an improved lens-walled CPC proposed by Li, et al. [62-64] which adding a thin air gap between the CPC-shape lens and the CPC reflector to improve the optical performance. Lenswalled CPC can be utilized in PV or PV/T system with the advantages of light weight and more uniform illumination.

\subsection{Design considerations in material}

In accordance of the CPC structure, it can be divided into side wall material and dielectric filled material generally. Considering the application of CPC for concentrating and illumination, the side wall of CPC is made by reflective material or the material with reflective coating. The metal with 
high reflectivity, such as stainless steel [65-67], aluminum [67], aluminum plating [67, 68] and Nickel-Gold plating [22]. Except metal, dielectric material is also another choice for side wall with metallic coating on it $[22,69,70]$. For dielectric filled CPC, the common optical materials in useful visible and infrared regions can be utilized as the dielectrics depending on the requirements of refractive index, for instance, clear polyurethane [71, 72], PMMA (poly methyl methacrylate) also called acrylic [70], and borosilicate glass [73], etc.

The selection of material depends on both the properties and the manufacture requirements of it. Most of CPCs are formed by the Computer Numerical Control (CNC) technology which can produce a one-off as effectively as repeated identical production. It is an automatic and precise system. However, when producing small or complex CPC components, the accuracy of CNC should also be taken into account. Van Dijk, L. et. al. [51] manufactured several CPCs in different shapes by 3D-printing in high fabrication accuracy successfully. They obtained the 13\% improvements on short circuit current of CPV system with 3D printed CPCs. Molding is another way to fabricate precise CPCs, especially dielectric CPCs, with high accuracy molds. It can also be applied to creating the CPCs in more complicated shape. For some particular designs, like microstructure CPC array proposed in the study by Walze et al. [70], the PMMA is manufactured by interference lithography. The metallic coating can be finished by sand blast technique [22].

When CPC incorporates with PV cell, the encapsulant between them is also need to be taken into account. A silicone elastomer (Sylgard-184) is a common encapsulant in CPV systems which has excellent transmission properties within the UV-visible spectral range with refractive index 1.5 $[72,74,75]$. Baig et al. [76] found that when the thickness of encapsulant interface becomes thicker, the optical and energy performance of Crossed CPC (CCPC) system will decrease.

\subsection{Solar geometry and tracking system}

\subsubsection{Solar geometry}

For trough CPC, its long axis is positioned along east-west direction, the normal to the apertures is tilted downward from the zenith which is called tilt angle of CPC, and the position of 3D CPC follows the same principles. Based on the sun movement, the annual solar collection is expected to be maximum when the tilt angle equals the local latitude. According to Fig. 9, the cosine of the angle of the incident ray is [77]:

$$
\cos \theta_{i}=\sin \alpha \cos \beta+\cos \alpha \sin \beta \cos (\gamma-A)
$$

If assuming the direction solar radiation is $I_{\text {direct, }}$, the solar radiation at the normal direction $I_{r}$ onto the surface of CPC entry aperture is [77]:

$$
I_{r}=I_{\text {direct }} \sin \alpha \cos \beta+I_{\text {direct }} \cos \alpha \sin \beta \cos (\gamma-A)
$$

The annual collection of CPC can be roughly predicted by the Eq. (7) (8) and optical efficiency based on the direct and diffuse solar irradiation in weather data. Yu and Su [78] introduced a concept of inner south projection angle that considering solar altitude, solar azimuth, CPC tilt angle and refractive index of dielectric, which provides a novel approach for indicating solar radiation through dielectric-filled CPC.

\subsubsection{Consideration of tracking system}

In accordance to CPC geometry, it can be seen that the larger the concentration ratio is, the smaller the acceptance angle will be. The CPC, or most nonimaging optics are designed to have good concentration without tracking because they can achieve the widest possible angular field of view for a given geometric concentration. Thus the geometrical design of CPC is the most important factor to determine whether the stationary or passive tracking mechanism would be utilized [79]. The stationary concentrator, which is fixed throughout the whole year, can provide the concentrations from low to moderate $(1.1 \times \sim 2 \times$; in special cases, up to $4 \times)$. For example, A design of stationary concentrator with larger acceptance angle $\theta_{c}=55^{\circ}$ and lower concentration ratio $C_{\text {geom }} \cong 1.1 \times \sim 1.2 \times$ can receive the sunlight up to $7.3 \mathrm{hrs}$ per day throughout the year when it is positioned along either horizontal (east-west) position or polar (north-south) position. The most common stationary CPC is with the half acceptance angle $\theta_{c}=35^{\circ}$ and concentration ratio $C_{\text {geom }} \cong 1.3 \times \sim 1.6 \times$ [41].

However, in some applications such as concentrating photovoltaic and concentrating solar thermal requires higher concentration for more irradiation or higher temperature. The 
concentrators with slightly higher concentrations $(\sim 3 \times \sim 10 \times)$ or higher concentrations $(>10 \times \sim 40,000 \times)$ are needed. The former usually with seasonal adjustment to collect more diffuse insolation. The concentrators with higher concentrations $(>10 \times \sim 40,000 \times)$ would be incorporated with tracker. The concentrator in this level collects more "circumsolar" radiation rather than diffuse insolation. Nonimaging optics, especially CPC, can provide lager optical tolerances so that the requirements of tracker accuracy are not that high. However, utilizing tracker is still not always practical: the precise solar trackers are sufficient expensive; utilizing trackers bring installation difficulty; the moving mechanical parts may reduce the reliability of whole system; the trackers consume electricity as well; not all applications are appropriate for installing trackers [49]. Therefore, when high concentration is not significant, the non-tracking system has high priority to be considered.

\section{CPC studies in literature}

In this section, a series of experimental and theoretical studies about CPC are presented. The literatures will be categorized according to their applications. In the first part, several PV systems employing CPCs as concentrators are introduced, which are classified based on CPC geometry. In second part, CPC working on solar thermal is discussed. Section 3.3 demonstrated that how CPC cooperates with daylighting in either control or collection. The last part talks about some typical areas that CPC is involved to. Fig. 10 illustrates a flow chart of this section. It is important to mention that the CPC studies presented are expected to be comprehensive to cover all of its applications but there might be some missed published but its knowledge contribution is still appreciated.

\subsection{CPC in photovoltaic system}

According to recent data by SolarPower Europe (the new European Photovoltaic Industry Association EPIA) [80], the cumulative capacity of global solar photovoltaic (PV) achieved 178GW in 2014, and it is predicted that there will be 540GW market of PV in the next five years. On the other hand, the massive cost reduction (75\% reduction on PV price in less than 10 years) also speeds up the popularization of PV technology. Concentrating photovoltaic (CPV) is a part of PV technology which focuses on capturing more light to generate energy by minimising the usage of PV. Therefore the optical devices are employed. Although CPV only offers $357.9 \mathrm{MW}$ in the total installed capacity in 2014, this will reach 1GW in 2020 [81]. As shown in the hierarchy of CPVT (Fig. 11), CPC is one of the key optical devices utilized in CPVT and lots of studies have been conducted in this area [82]. It concentrates solar radiation onto PV with intermittent tracking or without tracking in view of its wide acceptance angle. The concentration ratio determines the enhancement of relative radiation on PV. The flux distribution and temperature of PV are two main factors to improve PV efficiencies. Most researches about CPC with PV focus on the amount of collected light and radiation distribution on PV cell. In addition, with the consideration of cell temperature, $\mathrm{PV}$ is usually coupled with thermal system to remove heat or generate thermal energy simultaneously. Therefore, PV/T system is also a common type when designing the PV system with CPC. The CPVs will be introduced and classified in different shapes in this section.

\subsubsection{D trough CPC}

2D trough CPC is the most popular type for PV application in practice. A 2D CPC integrated with single-pass photovoltaic/thermal (PV/T) solar system was designed and tested by Sun and Shi [65] The trough CPC was made by a mirrored stainless steel material. The hybrid system had solar cells on base of CPC and fins attaching to the back side of PV panel to speed up the heat transfer to the air in chamber, as shown in Fig. 12. Experiments were taken outdoor to investigate the electrical and thermal performance under real weather conditions. Results implied that the air cooled down the solar cell effectively when the velocity was increased. The maximum short circuit current was higher than twice of the current of standard PV panel. On the test taken on $20^{\text {th }}$ of Aug, the maximum temperature rising was $13^{\circ} \mathrm{C}$ and the thermal efficiency increased from $60 \%$ to $70 \%$ at the same time. Karathanassis et al. [83] designed a similar CPVT system consisting plate-fin cooling channels under the PV cells attached on the CPC base, which provides 
$6 \%$ electrical efficiencies and $44 \%$ thermal efficiencies at the same time.

In another CPC PV/T system (Fig. 13) with cooling pipes [53], effects of glazing cover and cooling pipes were investigated according to the optical, thermal and electrical performance. The intermittent tracking is required for this system. It was found that the 2D unglazed CPC improved the electricity generation by $49.4 \%$ of solar cells. The glazing cover was not suggested owing to the reduction of electric output and increase of heat gain, but the compensation and dust should be paid attention on uncovered solar cells. The cooling pipe could increase the electricity generation considerably and thermal gain of PV/T system. Following the previous work, Bahaidarah et al. [66] did a comparative experiment for the 2D unglazed trough CPC with cooling pipes. The other three test prototypes for comparisons were the flat PV with cooling, flat PV without cooling and unglazed CPC without cooling. The experiments results demonstrated that the PV with CPC and cooling generated the electricity most, which was twice as much as the PVCPC without cooling generated and $61.9 \%$ higher than the flat PV strings with cooling generated. Except for individual CPC, some lenses with special shapes are integrated to CPC to enhance its concentration. Grasso et al. [84] proposed a trough CPC integrated with a prism for PV application. As shown in Fig. 14, CPC is reflective as primary concentrator and prism is dielectric with high refractive index. PV cell is attached on base of CPC. According to the ray tracing and prototype test, the geometrical concentration ratio of it was $5 \times$ and the effective optical performance ratio was up to $81 \%$.

Another example of several concentrators in PV system is incorporating CPC and Fresnel lens. Chen $[85,86]$ patented a kind of high concentration system, which consists three or four optical concentrations as shown in Fig. 15. One or two layers of Fresnel lens are located above a trough $\mathrm{CPC}$, and a third or fourth concentrator which is glass lens with reflective coating is attached then with PV cell. Therefore the whole system can enhance the solar intensity 300 to 1000 times within a six-inch distance. This kind of design is applied to PV power generation mostly.

\subsubsection{Lens-walled CPC}

Except conventional 2D CPC, lens-walled CPC may play an important role in PV concentration as well. Su et al [59] investigated the optical performance of lens-walled CPC with the comparison of conventional 2D reflective CPC and dielectric filled CPC. Under the incident light with different angles, results showed that the lens-walled CPC has great advantages on acceptance angle and flux distribution on base. It had higher optical efficiency than reflective CPC but slightly lower than dielectric filled CPC. In terms of annual solar energy collection, six cities which were Birmingham, Paris, Rome, Beijing, Hefei and Shanghai were selected as examples [60]. The monthly accumulative solar energy collection demonstrated similar results. The collected solar energy by lens-walled CPC was $20 \%$ less than dielectric filled CPC and $20-30 \%$ more than reflective CPC. However, lens-walled CPC has outstanding feature of its light weight compared to solid CPC and almost same cost on manufacture. Li et al. [61] evaluated the flux distribution and PV performance of test prototype for lens-walled $\mathrm{CP}$ and compared to the reflective CPC. Experiment results demonstrated that the lens-walled $C P C$ had more uniform flux distribution on PV according to the change of fill-factor, which caused higher efficiency and output of PV cell.

Based on the previous researches, an improvement of lens-walled CPC was put forward by adding an air gap between the lens structure and reflector [62], as shown in Fig. 16. A test prototype of a lens-walled CPC with air gap was made for experiment to compare with reflective CPC and traditional lens-walled CPC. It was found that the lens-walled CPC with air gap can reduce more optical losses compared to other two CPCs. For irradiance distribution on PV, the two lens-walled CPCs have similar performance but both of them were better than reflective CPC.

The lens-walled CPC integrating with PV/T system was also explored $[63,88,89]$. Fig. 17 illustrates the structure of the whole system: the solar cell is in the middle of encapsulated materials; CPC is fixed on a square tube with insulation. Comparing with the PV/T system without concentrator, it showed the great advantages of lens-walled CPC on concentration: the average optical efficiency was up to $83 \%$ when the incident lights were within the half acceptance angle. The experiment under real sky showed that the overall optical efficiencies of a daytime were $62 \%$ and $67.9 \%$ for $31^{\text {th }}$ of March and $13^{\text {th }}$ of May [63].

\subsubsection{Crossed CPC (CCPC)}


Because CCPC is created by combining two 2D CPC, CCPC performs well in PV generation. Sellami and Mallick [90] compared the optical efficiency and the flux distribution between 3D CCPC and $3 \mathrm{D}$ revolved CPC to investigate their potential when cooperating with PV. The CCPC with concentration ratio $3.6 \times$ and half acceptance angle $30^{\circ}$ was found to be an ideal concentrator. Similar to revolved CPC, the maximum optical efficiency of CCPC reached to $95 \%$, but CCPC with square entry and exit aperture of CCPC could reduce the losses more [91]. They also made a test prototype of CCPC, which had reflective film covering on inner surfaces and PV cells on base. Both simulation and experiment results demonstrated that the optical flux distribution was not uniform at the exit aperture. Some of the hot spots could as 50 times higher than incident light that would decrease the efficiency of solar cells.

With the consideration of temperature influence on PV, the air flow and temperature distribution of an isolated CCPC with solar cell was investigated [92]. The side walls made by dielectric materials were covered with reflective film of CCPC prototype. It was found that a vortex-loop changes with the incident sunlight in the filled chamber. The high temperature core on solar cell was supposed to decrease the efficiency of solar cell.

Apart from reflective CCPC, the potential of dielectric filled CCPC has been explored. Baig et al. [71] simulated and tested the optical and energy performance of a 3D dielectric filled CCPC with $1 \mathrm{~cm} \times 1 \mathrm{~cm}$ solar cells on base. The dielectric filled material was clear polyurethane. It was found that the maximum optical efficiency reached $73.4 \%$ and the maximum power ratio was 2.67 . The experiment results demonstrated the non-uniformity of flux distribution results in the decrease of power output for solar cells. The operating temperature also applied parasitic effects which is up to $14.6 \%$ decrease on the power generation of PV cells as well.

Taking into account the escaping light from edges of CPC, the dielectric filled CCPC with reflective film on edges has been put forward. In the study [76], the influence of reflective film on edges and encapsulant interface on trapping the light escaping were mainly discussed as shown in Fig. 18. Results demonstrate that the optical efficiency increased from $55.6 \%$ to $84.5 \%$ when the thickness of encapsulant spillage decreased from $3 \mathrm{~mm}$ to $0.1 \mathrm{~mm}$. The reflective film along the edges reduced the optical losses effectively. The positive effects by reflective film also reflected on the energy output of solar cells. The maximum increase $8.5 \%$ of short circuit current was and $6.6 \%$ of maximum power ratio. Another study [93] investigated and proved that the partial reflective coating of edges also works on $2 \mathrm{D}$ dielectric filled CPC, which could improve the optical efficiency by $13.5 \%$. Lamnatou et al. [94] also proposed that the reflective film on edges of $2 \mathrm{D}$ dielectric filled CPC could provide $11 \%$ reduction in energy payback time and $12 \%$ reduction in greenhouse-gas payback time for a CPV system.

CCPC can also be integrated with non-imaging dish concentrator (NIDC). According to Fig. 19, the NIDC is primary concentrator with the rim angle of $\theta$ and the dielectric-filled CCPC is secondary concentrator. It is a sun-tracking and dense-array CPV system. The larger entrance aperture of CCPC components provide more space for flexibility of inter-connection among PV cells; the square exit aperture of CCPC suits the commercial PV cell very well. This system [95] was compared to normal dense-array CPV (DACPV) module for different pointing errors. Results showed that the NIDC+CCPC module used 77\% less CPV cells than DACPV module but performed better electricity output. Chong et al. [96] put forward another concentrator photovoltaic system using NIDC as the primary concentrator and CPC as the secondary concentrator. The two concentrators were positioned face to face and the NIDC was designed to produce uniform solar flux distribution onto the top of CPC with PV attached on base. The on-site measurement in Malaysia showed that the system efficiency of this CPV system was $17 \%$ and the maximum output power was $639 \mathrm{~W}$ as the direct normal irradiance was normalized to $1000 \mathrm{~W} / \mathrm{m}^{2}$.

\subsubsection{D revolved CPC}

As indicated in previous sections, CCPC performs less optical losses than 3D CPC. However, 3D CPC is also worth to be explored in PV application. Arnaoutakis et al. [73] integrated dielectric compound parabolic concentrators (dCPCs) with a planar bifacial silicon solar cell (SC) and a $25 \%$ Er3+ doped hexagonal sodium yttrium fluoride ( $\beta$-NaYF4:Er) up-conversion (UC) phosphor as shown in Fig. 20. The functions of dCPCs are concentrating, transmitting broadband of the excitation and coupling the isotropic emission. The dielectric filled material was B270 borosilicate 
glass. The critical findings were the efficiency increased $32 \%$ under sub-band-gap illuminance and the external quantum efficiency (EQE) was increased from $1.33 \%$ to $1.80 \%$, which implied the capability of ACPC cooperating with UC-SC due to enhancing the concentration in forward direction and in the same time maintaining high collection efficiency of UC emission in the reverse direction. The design also provides a way to optimize the solar concentration on UC phosphor independently for the solar cell as required.

Similar to 2D CPC, 3D CPC can also integrate other lenses to enhance its concentration. Andreev et al. [97] proposed a reflective 3D CPC with a convex lens as secondary concentrator for electricity generation as shown in Fig. 21. The PV cell is AlGaAs-GaAs heterostructure attached on base of CPCs. The convex lens on CPC base could increase the concentration ratio of CPC from 21 $X$ to $30 \times$. The optical efficiency of the whole system could reach $90 \%$.

\subsubsection{Variable-focus-parabolic (VPF) and rotationally asymmetrical compound parabolic concentrator (RACPC)}

In order to solve the problem of non-uniform flux distribution, a novel parabolic concentrator called variable-focus-parabolic (VFP) reflector was proposed by Tsai [98]. It has a square solar cell on base, and the focal length varies as a function of the horizontal displacement of the incident point relative to the vertical centerline of the solar cell on base. Two types of VFP reflectors with circular focus spot and square focus spot were designed and compared. Fig. 22 shows a cross section of the VFP reflector with square spot and two different focus spots. In this research, the performance of VFP reflector were compared with the conventional standard parabolic concentrator by exact analytical model and skew-ray tracing approach. The geometry of VFP reflector was optimized in order to maximize the uniformity of flux distribution on solar cells. Results illustrated that the four-step VFP reflector that guided up to $89.8 \%$ incoming rays onto the solar cell and improved uniformity of flux distribution by $92 \%$, which provided great advantages to conventional standard parabolic concentrator.

Abu-Bakar et al. [99] designed a novel rotationally asymmetrical compound parabolic concentrator (RACPC) and did a series of research [100] on it. The RACPC shown in Fig. 23 has the planar entry aperture with four axis of symmetry and square exit aperture. The test prototype of RACPC was integrated with a $1 \mathrm{~cm}$ by $1 \mathrm{~cm}$ monocrystalline laser grooved buried contact silicon solar cell. Both of simulation and experiment results demonstrated that the RACPC provided good concentration gains within its designed acceptance angle. Comparing with a bare solar cell, the short circuit current was increased by 3.01 times and the maximum power was increased by 3.33 times.

\subsection{CPC in solar thermal}

The CPCs utilized in solar thermal systems will be introduced in this section. The working principle is quite same as CPV system, which is concentrating more light onto an absorber near the base. A CPC can be designed into different shapes to meet the requirements of a variety of absorbers. Different from CPV, the concentration ratio of CPC in collector can reach 10 without diurnal tracking. Vacuum technology will be applied for evacuated tubular absorber to surround the surface of absorber that is often a selectively coated pipe with a double-walled evacuated glass tube [36]. Researches in this section are about the design of CPC and tubular absorber to improve the thermal efficiency of collectors.

\subsubsection{Traditional CPC solar collector}

The CPC with tubular absorber is a common solar thermal collector, especially in domestic hot water heating system. The researches on it have lasted several years, and were mainly based on numerical model and experiment prototype. The numerical model is an important and accuracy tool to design system, validate experiment results, and optimize the system performance [101]. Ortiz-Rivera and Feliciano-Cruz [102] evaluated thermal performance of a solar thermal power plants with CPC as solar collector in Puerto Rico. The local weather data were considered. Results showed that under sunny sky conditions, more solar radiation was collected, but the power output decreased under cloudy sky conditions depending on the solar transients: system could return to stable energy output with short appearance (5-10 mins) of cloudy sky; the power generation would reduce greatly even to zero when the sun is missing for a long time. 
Because of concentrating solar radiation onto base surface, CPC is also attempted to be integrated with flat absorber. Al-Ghasem et al. [103] tested a prototype performance of 2D trough CPC with a flat absorber on base under Jordan, Irbid climate from March to May in 2013. The flat absorber was designed to be a heat source for the applications in low temperature range (below $90^{\circ} \mathrm{C}$ ). Results showed that comparing with stationary $\mathrm{CPC}$, the tracking one increased the highest temperature of absorber by $27.7 \%, 16.7 \%$ and $8.3 \%$ for March, April and May respectively, but the cost of tracking system which occupied $38.6 \%$ of the whole test system should be taken into account. Mishra et al. [104] optimized the U-shaped evacuated tubular collector (ETC) by integrating with compound parabolic concentrator in accordance with the analysis of energy matrices.

Ratismith et al. [105] proposed the performance of two novel CPCs for solar thermal collection, as shown in Fig. 24, one is double-parabolic trough (DPT) and the other is flat-base trough (FBT). Both of them have a double sided absorber plate in middle. The ray tracing results demonstrated that the FBT with vertical alignment of double sided absorber plate was more efficient than the DPT with horizontal alignment of absorber. The prototype of FBT was tested under real sky condition in Bangkok with the comparison of 512 SUNDA-Seido standard flat-bed collector [106]. Because FBT applied wet metal-to-water contact so that provided effective heat transfer comparing with commercial collector with dry metal-to-metal contact. It generated almost same energy compared with common commercial collectors but with $50 \%$ less evacuated tubes, which led to $30 \%$ less cost in manufacture. In addition, the high temperatures $\left(>100^{\circ} \mathrm{C}\right)$ provided made it to be capable in either domestic or industrial use.

Expect the effects by parabolic wall of CPC collector, the tubular absorber also plays an important role in energy receiving. Adbullahi et al. [107, 108] compared the performance of four CPC collectors with different absorbers (Fig. 25). Comparing with conventional collector with one tubular receiver, the one with two receiver aligned horizontally and with elliptically shaped receiver increased the daily optical efficiency by $15 \%$ and $17 \%$ respectively. Locating two receiver in vertical could not improve the optical efficiency. In addition, the heat transferred to the cooling water by the collector with double tube receivers outperformed the collector with single receiver by $21 \%, 19.8 \%$ and $18.3 \%$ for acceptance angles of $30^{\circ}, 40^{\circ}$ and $60^{\circ}$ respectively. These results are significant to improve the solar thermal collector by changing the tubular absorber. Gang, P., et al. [109] proposed another novel CPC solar water heater with a U-pipe inside the tubular absorber. The experiment results show that the overall thermal efficiency of this system is still high, above $49 \%$, when the hot water in is at higher temperature $\left(55-95^{\circ} \mathrm{C}\right)$. In addition, the exegetic efficiency is above $4.62 \%$ at the same time. This design provides a new idea to solve the problem of low efficiency under higher water temperature of common solar water heater.

$\mathrm{Xu}$ et al. [110] proposed to replace the tubular absorber in traditional CPC collector by a closedend pulsating heat pipe. The concentration ratio of CPC was 3.4 and the diameter of heat pipe is $4 \mathrm{~mm}$ for the experiment prototype. HFE7100 was used as the working fluid at a filling ratio of $40 \%$. The thermal efficiency of prototype was as high as $50 \%$ when the normal radiation is $800 \mathrm{~W} / \mathrm{m}^{2}$.

In order to obtain more solar energy, some CPC solar collector cooperates with tracking system. Wang et al. [111] investigated the effects of tracking mode on a tracking compound parabolic concentrating (TCPC) solar collector. The schematic view and photo of TCPC collectors are shown in Fig. 26. The main parts are reflective trough CPCs, evacuated tubular collectors and tracking mechanism. The CPC is with the concentration ratio of 2.3. The tracking mechanism has three different modes, which are fixed mode (FM), intermittent tracking mode (ITM) and continuous tracking mode (CTM). It was found that the average optical efficiency of ITM was the highest which reaches $63.6 \%$ among the three modes. It also provided highest output energy based on daily operation data.

\subsubsection{Hybrid solar collector with CPC}

Ulavi et al. [112] designed a hybrid CPC-PV/T system with wavelength selective film as shown in Fig. 27. The film is integrated with $C P C$ to reflect the solar radiation in infrared portion onto tubular absorber and transmit the visible spectrum to the thin PV film on base. Results showed that the total energy conversion efficiency of CPC-PV/T system was $20 \%$ higher than the 
independent PV and solar modules, while the individual efficiencies of electricity and thermal were decreased. This hybrid system still has potential if the energy requirement of per unit installed area is high.

In respect of solar thermal, there is also an application in which CPC is worked with Fresnel reflector together. Yanhua et al. [113] investigated the thermal performance of this kind of concentration system shown in Fig. 28, which constitutes a linear Fresnel reflector concentrator (LFRC) with mirrors on bottom and reflect solar radiation into the top CPC absorber. The thermal analysis determined that the temperature of absorber increased with the length of receiver tube significantly, but the total heat loss would increase as well. Reducing the heat loss through the glass pane was an efficient way to solve this problem. The optical parameters of concentrator were the key to thermal performance, and the improvements could be made on transmittance of glass pane and reflectivity of CPC. Prasad et al. [114] tested the similar system in Vallipuram $\left(12^{\circ} \mathrm{N}, 79^{\circ} \mathrm{E}\right)$, India and it was found that the optical efficiency was $76.4 \%$ and the coefficient of flux variation was 0.13 . Baljit et al. [115] utilized Fresnel lens as glazing cover and primary concentrator onto the conventional PVT-CPC system. The maximum efficiency was up to $90 \%$ when this system was incorporate with dual fluid. Ma et al. [116] proposed a novel compound cylindrical solar concentrator (CCSC) which comprised of cylindrical Fresnel lenses, parabolic reflectors, secondary reflector, evacuated tube receiver and single-axis tracking. The optical efficiency of this system was as high as $84.1 \%$ which means it utilized the solar radiation efficiently. It could provide heat at $200{ }^{\circ} \mathrm{C}$ easily and the highest temperature was about $250^{\circ} \mathrm{C}$ under the solar radiation of $1050 \mathrm{~W} / \mathrm{m}^{2}$.

\subsubsection{CPC in ICSSWH system}

2D trough CPC with tubular absorber for solar thermal collection were introduced in previous sections. There is another innovative 'integrated collector storage solar water heaters' (ICSSWH) [117], of which un-truncated CPC was applied as primary reflector. The structure of ICSSWH is shown in Fig. 29: the CPC is connected with a $120^{\circ}$ reverse circular reflector, a tertiary cavity and the storage vessel. The collection efficiency of this system was around $53 \%$, and the water in vessel could be heated reaching to a temperature rise of $32^{\circ} \mathrm{C}$.

\subsubsection{CPC in Organic Rankine Cycle (ORC)}

Antonelli et al. [118] proposed a small scale Organic Rankine Cycle (ORC) plant utilizing CPCs as heat source and a volumetric machine as an expansion device. The CPC collector is a traditional trough CPC reflector with a tubular absorber at bottom (Fig. 30 a)). The tubular absorbers are commercial U-pipe evacuated tubes as shown in Fig. $30 \mathrm{~b}$ ). Results showed that the best performance of the solar collector part was to ensure at least 3000 operating hours per year. The energy production was maximized when concentration was between 1.1-1.4 and the tilt angle was smaller than $20-25^{\circ}$. In addition, they also put forward that a proper choice of concentration ratio and tilt angle could reduce the initial investment cost of the components. Tiwari et al. [119] integrated a novel glazed reverse absorber conventional compound parabolic concentrator (GRACCPC) in a recuperated organic Rankin cycle which utilized low global warming potential and zero ozone depletion potential working fluid mixture of cyclohexane/R245fa. The temperature at outlet of the test prototype could reach $398 \mathrm{~K}$ at noon.

\subsubsection{CPC in water steam generation and distillation system}

The principle of CPC being used in water steam generation and distillation system is quite similar to that in solar thermal heating, which is concentrating light onto an absorber. Singh and Tiwari $[120,121]$ utilized a PVT-CPC active solar distillation system in their study of investigating the effect of water depth of distillation system. Nishi and Sema [122] tested a prototype of this kind of system with a 3D reflective CPC as concentrator, as shown in Fig. 31. It was found that the maximum exergy efficiency of this system could reach $12 \%$ when the flow rate was maximum. Elashmawy [123] investigated the performance of tubular solar still incorporating with CPC and manual tracking system in Hail city $\left(27.5^{\circ} \mathrm{N}, 41.7^{\circ} \mathrm{E}\right)$, Saudi Arabia. Results showed that the new distillation system provided lower cost and its productivity was about six times higher than traditional tubular solar still.

\subsubsection{CPC in soil heating}


Noyes [124] referred to a special application of CPC which is heating soil. The working process is intensity source for soil heating, CPC is utilized to catch sky light and direct sunlight and integrated to optical fibres which can transmit solar radiation in long distance and still maintain high efficiency. Although heat loss will occur during transmission, the heat can be still radiated to the collecting surfaces in view of the relatively low temperature.

\subsection{CPC in daylighting}

The benefits of daylighting on visual comfort, human health and energy saving have been discussed for decades. With the rising of energy problems, daylighting becomes a significant part in new building design for the purpose of sustainability. CPC has been used for concentration application in the past, however its potential in daylighting was discovered in recent years. CPC can be mainly utilized in two different ways when it works with daylighting: the one is to control sunlight in different incident angle, as it is used on window and skylight; the other is to collect and guide more sunlight to interior, in the application of light pipe or funnel. In this section several researches investigated the possibility of CPC in daylighting application will be introduced.

\subsubsection{CPC in daylighting control}

Walze et al. [70] put forward two smart windows with the microstructure of 2D CPC array on surface. It can reduce the unneeded solar radiation by refraction or diffraction and improve the light-guiding abilities with the control of switchable coatings. For the first type, the microstructure on surface is 2D CPCs with the period of $9.1 \mu \mathrm{m}$ and a switchable metallicmirrored coating on base, as shown in Fig. 32 a). The replication of CPC array is manufactured by interference lithography in PMMA [70]. Solar radiation will be selectively transmitted according to its incident angle. This smart window can reduce the CPC in mirror state when the light is within the acceptance angle, and more light can be prevented by switch on the mirrored coating. Another smart window has same working principle but the reflective coatings are on one side wall of CPCs as shown in Fig. 32 b). It causes opposite effects on sunlight which is accepting the light with smaller incident angles and preventing those with larger incident angles.

In macro view, CPC controls sunlight in similar way. Yu et al. [125] explored the feasibility of 2D dielectric filled CPC (dCPC) in daylighting control when it is used as skylights for atrium. Results showed that when it was east-west orientated, the transmittance it provided would be lower at noon and larger in the morning and afternoon under sunny sky conditions in summer time, which is significant to control the indoor heat gain. In cloudy day, transmittance of it would stay at a relatively high level due to the diffuse skylight. They also tried to integrate the 2D dCPC with PV cells on base, and it achieved that generating electricity and control daylight at the same time. But the transmittance of the $\mathrm{dCPC}$ with PV was lower than the one without PV panel.

Another hybrid solar window focusing on solar thermal collection was introduced by Ulavi et al. $[126,127]$, which consists of 2D CPCs and a tubular absorber as shown in Fig. 33. The CPC is coated with a wavelength selective film for two functions: reflecting or concentrating the solar radiation in infrared portion onto absorber; transmitting the solar spectrum in visible portion into room. Single glazing and double glazing are attached with CPC to present the window glazing options. Simulations were considered when it was used as vertical window and horizontal skylights. Comparing with existing glazing technology in terms of visible transmittance, solar heat gain, U-factor and spectral selectivity, the hybrid solar window with double glazing had almost equivalent performance with low-e double glazing. According to the climate in Minneapolis, the annual thermal efficiency of double glazed type ranged from $21-26 \%$ when it was used for skylight and $15-24 \%$ for south or east facing windows with the adjustment of CPC geometries. In addition, this hybrid window could be switched to non-concentrating mode if the solar heat gain is too high.

\subsubsection{PRIDE}

The full name of PRIDE is 'Photovoltaic Facades of Reduced Costs Incorporating Devices with Optically Concentrating Elements', which is applied on building facade as double glazing and integrated photovoltaic system by concentrating technology. The first generation of PRDIEs was proposed by Zachharopoulos et al. [128]. Two designs (Fig. 34 a)) are introduced: the one consists 
of 2D symmetric CPC and an extra silvered dielectric circular reflector; the other is $2 \mathrm{D}$ asymmetric CPC with two parabolas in different acceptances. CPCs are stationary and dielectric-filled. For both designs, the optical efficiencies were higher than $90 \%$. Compared to the PV with flat covers, the solar radiation collected by asymmetric and symmetric CPCs were 2.3 and 2.7 times higher respectively under the weather data of Grete, Greece. However the asymmetric CPC maintains optical efficiencies more than $40 \%$ when the incident angles excessed the two-dimensional angular acceptance angle.

Mallick et al. $[67,129]$ tested a prototype of first generation PRIDE with the line-axis half acceptance angles of $0^{\circ}$ and $50^{\circ}$ (ACPPVC-50) by the outdoor experiment in Northern Ireland $\left(54^{\circ} 36^{\prime} \mathrm{N}, 5^{\circ} 37^{\prime} \mathrm{W}\right)$. The CPC reflector was made by stainless steel with reflective coating and attached PV cells on base. Results illustrated that the maximum power ratio of ACPPVC-50 was 1.62 which was $62 \%$ higher than the PV panel without concentration. The average temperature of solar cell for ACPPVC- 50 was $12^{\circ} \mathrm{C}$ higher than that of PV panel, and it resulted in the lower efficiency of ACPPVC-50.

In view of the excellent power output of the first generation for PRIDE which incorporated 3 and $9 \mathrm{~mm}$ wide single crystal silicon PV cells, Mallick and Eames [69] made an improvement of the first generation PRIDE concentrator with the selected 'Saturn' solar cells which was $6 \mathrm{~mm}$ wide, as illustrated in Fig. 34 b). The line-axis half acceptance angles of this $2 \mathrm{D}$ asymmetric reflective CPC are $0^{\circ}$ and $37^{\circ}$. The fabrication process of it was investigated in this research followed with cost analysis. Outdoor experiment demonstrated that the maximum power ratio was 2.01 comparing to the PV cell without concentration and electrical conversion efficiency of PV panel was $10.2 \%$. The cost of manufacturing process could be reduced by $42 \%$ after improvements. Sarmah and Mallick [130] modeled the secondary generation of PRIDE to optimize the cell metallization and analyze the temperature effects on the whole system performance, as well as the non-uniformity effects. It was found that both high temperature and un-uniform flux distribution on cell result in decrease of solar cell output.

Based on the previous works, Baig et al. [72] put forward the third generation of PRIDE concentrating system which was dielectric filled and with reflective film along the edges, called DiACPC (Dielectric asymmetric compound parabolic concentrator), as shown in Fig. $34 \mathrm{c}$ ). The line-axis half acceptance angles of this $2 \mathrm{D}$ asymmetric reflective $\mathrm{CPC}$ are $0^{\circ}$ and $55^{\circ}$. The reflective film was designed to catch the escaping light from the corner of CPC in order to reduce the optical loss. Experiment results showed that there was 15.9\% increase of average power output by comparing the DiACPC with and without reflective film while the temperature was keeping at $25^{\circ} \mathrm{C}$, and the improvement of performance was $6 \%$ if the thermal effects was taken in to consideration. In addition, the reflective films changed the hotpots position and peak illumination intensity. The maximum power decreased by $0.5 \%$ in view of the thermal effects for the DiACPC with reflective film and it was smaller than the $0.94 \%$ drop for the DiACPC with reflective film.

Sarmah et al. [74] investigated the performance of a 2D asymmetric dielectric-filled CPC with PV on base that is similar to the third generation PRIDE in northern latitudes $\left(>55^{\circ}\right)$. The line-axis half acceptance angles of this DiACPC are $0^{\circ}$ and $55^{\circ}$. The CPC with and without reflective film along the edge were compared. Similar to the previous researches, the DiACPC with reflecting film performed less optical loss, and its maximum power ratio reached 2.27 compared to the 1.97 of DiACPC without film. The electrical conversion efficiency was $9.43 \%$ in average within the range of acceptance angle. Based on the current market scenario, the DiACPC system could reduce up to $20 \%$ per unit power output comparing with the conventional PV module. Continuing to the previous research [74], Sarmah and Mallick [130] tested the performance of the same DiACPC with reflective film along the edge in Edinburgh, UK under different weather conditions. Results showed that the maximum power output of DiACPC was 2.27 times higher, and the average short circuit current was 2.22 times higher than those of conventional flat PV panel on sunny interval day. On rainy day, the average diurnal power of DiACPC was 2.17 times higher than the flat PV panel. The excellent performance of DiACPC in different weather also corresponded to the indoor test results. 


\subsubsection{CPC in anidolic daylighting system and light pipe}

Light funnel and light pipe are the new daylighting control strategies in recent years. CPC is also involved in the researches in these areas. Taengchum et al. [131] proposed a roof mounted light pipe with anidolic CPC to concentrate direct and diffuse sunshine into tubular light pipe. Due to the properties of CPC, it was found that CPC would reject the light with large incident angle which may not be suitable for collecting light as more as possible in light pipe application.

CPC is less optimistic as well in application of horizontal funnel. Wittkopf et al. [132] investigated the CPC feasibility when it was integrated with horizontal funnels for illuminating deep buildings. The innovative method called luminous intensity distribution curves (LIDC) derived from ray tracing was applied to compare the performance of different collectors shown in Fig. 35. New criteria such as 2D flux, percentage of 2D flux within a selected angle, horizontal offset angle and angular spread were proposed to quantify the optical performance of anabolic collectors based on LIDC. Type 4 and 5 are the CPC with an extra de-concentrator, and attach to two simple flat reference collector. However CPC collector is not optimal for the light funnels. The one with simple baffle and parabolic reflectors can capture more light owing to its larger entry aperture.

\subsubsection{CPC in Optical fibre guiding system}

Optical fibre has outstanding performance in transmitting light. Therefore CPC becomes an important component for light collection in application of optical fibre. Arashi et al. [68] tested a solar concentration system consisting of a parabolic dish concentrator, CPC and an optical fibre bundle. Because the collected solar radiation will reduce at the end of optical fibre, CPC was utilized to re-concentrate the light exiting from the end of optical fibre bundle, which improved the solar energy output by up to 3.5 times based on experiment.

On the contrary, CPC can also be used to concentrate light into optical fibre. Xue et al. [133] introduced a novel solar optical fibre tracking system consisting two CPCs as first and secondary concentrators and a cylindrical reflector in middle, as shown in Fig. 36. This system has the concentration ratio of 273 and can enhance the illuminance more than 10 times in view of several reflections and deflections in outdoor experiment; the transmittance ranges between $8 \%$ and $17.5 \%$ with the change of the length and diameter of optical fibre.

Two large-scale optical fibre daylighting system was put forward by Ullah and Shin [134] as shown in Fig. 37, the one uses parabolic trough and the other uses linear Fresnel lens to guide incident light to the trough CPC and then optical fibres for interior of multi-floor building. CPC is applied as a third concentrator to capture the concentrated light to light fibre. With cooperating with lightemitting diode (LED) light together, this system achieved better illumination quality and illuminance level than traditional lighting systems.

\subsection{CPC in photocatalytic water degradation and purification}

Except the three main applications, PV, thermal and lighting, CPC also plays an important role as a reactor in photocatalytic water purification owing to its high commercial potential of simplicity, cost effectiveness, easy operation and low capital investment [135]. As the most advanced nonconcentrator solar reactor, it has outstanding performance in photocatalytic degradation of refractory organic compound and photocatalytic disinfection of water [136]. Fig. 38 demonstrates a typical CPC photocatalytic water purification system. The CPC has similar structure with solar thermal collection system which contains two parabolic curves and a tubular tube in middle. The reflective surfaces of CPC catch UV sunlight without tracking system, and provide a $360^{\circ}$ illumination over the tubular reactor. The reflective surfaces are coated with $\mathrm{Al}$ and TiO2-SiO2 so that the usage efficiency of UV range of solar spectrum reached $95 \%$. The water flowing through tubular reactor could reclaim $99 \%$ of $\mathrm{TiO}_{2}$ from the slurry. Tanveer and Tezcanli Guyer [136] summarized five main design parameters of CPC that affect system performance, which are reflective surface, absorbing tube material, absorbing tube diameter, acceptance angle and radiation absorption; to make the degradation system work more effectively, photocatalytic type, catalyst loading, reaction $\mathrm{pH}$, and light intensity are the important parameters of photocatalytic reactor should be considered.

\section{Simulation Tools}


In this section, eleven simulation tools which are all useful in analyzing the systems with CPCs will be introduced. All of them were used by the CPC studies referred in Section 3. Table 1 provides a summary of them which labeled their key features and required operating platforms. Each one has specific characteristics that can satisfy various requirements of different users. The software provide not only optical analysis of CPCs, but present thermal and electrical simulations if needed. In general, they can be divided into two types, one has graphical user interfaces between user and the software which benefits the users who have few knowledge of computer programming or of the mathematics and equations that govern building physics, such as LightTools, ZEMX, APEX, OptisWorks, Radiance and Photopia; the other is high-level language and interactive environment that requires specific code or module input for simulation, which is suitable for the users who are familiar with programming, mathematics, physics or require particular principles, equations or modules for simulation, like MATLAB, Energy Equation Solver (EES), COMSOL Multiphysics. In most software, Monte Carlo method, which provides numerical results by repeating random sampling, is a main technology in optical simulation. All of them are professional and widely used in either academic research or commercial development. In CPC simulations, users can select the most suitable one for themselves based on their requirements, such as operating system, interactive environment, results type, flexibility and simplicity, etc.

\section{Observations and outlook}

\subsection{Summary and observations on CPC studies in literature}

Table 2 summarizes and compares all CPC-focused studies referred in Section 3-4. Fig. 39 demonstrates the relationship between CPC types focused with respect to publication year of study. Although CPC has been proposed for decades, there are not many studies of it between 2000 and 2013. The investigation of it began to increase in recent 3 years. It can be seen that the reflective CPC (both 2D and 3D) acted as the main type that was focused by researchers among all CPC types. However, from 2014, the dielectric filled CPC was paid attention to by researchers and it took a large proportion in 2015. Fig. 40 illustrates the CPC studies according to concentration ratio with respect to application area. The main area of CPC being utilized was PV as an attractive concentration facility without tracker. It was also popular in solar thermal and daylighting. As a low concentration optic, the concentration ratio of most CPCs in application ranged between $2 \times \sim 4 \times$. Fig. 41 presents the countries that put forward CPC studies. CPC was proposed by Winston in USA, but most of the focused studies in recent years were done by UK which took $30 \%$, and then China took $21 \%$. USA and Japan occupied $6 \%$ and $5 \%$ respectively.

\subsection{Prospects and outlook}

Based on the literature review above, several recommendations can be put forward which may be improved in the future work on CPC.

1) CPCs geometry and edge effects

CPC can be designed in various shapes. However, the pros and cons of any new design should be considered first in practice. In terms of dielectric filled CPC, the weight of it is a disadvantage when it is applied as building facade and skylight. Truncation is one of the basic approaches to mitigate this. In addition, the lens-walled CPC can be proposed to solve this problem with maintaining the large acceptance angle.

Almost every research of CPC discussed the optical losses due to the light escaping from its edges, especially for dielectric filled CPC. In some PV applications, reflective films or partial coatings are utilized on the edges of CPC to weaken the edge effects [72, 76, 91-93]. The edge effects are also determined by the geometry of CPC. Several studies [90, 91, 99] demonstrate that comparing with polygonal CPC, the revolved symmetric CPC leads to more losses on edge area which results in decrease of optical efficiency. However in some hybrid systems, the escaping light are applied for energy generation [112] or daylighting [125]. Hence, with the innovative design, the escaped light can be overcome or reused.

In addition, when CPC components are applied to build a CPC panel, the optical losses on connecting edges are significant. Comparing with revolved CPCs, some polygonal CPCs can be 
positioned next to each other without any extra junctions. In respect of manufacture, polygonal CPCs are easier and more economic to be fabricated under the current manufacture technology with the consideration of massive production.

2) Manufacture effects

Manufacture effect is an important factor that cause the deviations of experiment results [74]. It is based on the current fabrication technology. As discussed in Section 2, the excellent design, materials and manufacture process should be considered to improve its precision in massive production.

3) Tracking system

The requirements of tracking system should be considered when a CPC is designed. Generally CPC is non-tracking. But for some particular application in which CPC has higher concentration ratio, 2D CPC may need one-axis tracking and 3D CPC may need two-axis tracking. The accuracy, complexity, maintenance and lifetime of trackers need to be calculated. In addition, the cost on tracking system should be taken into account. For instance, a tracking system of a 2D trough CPC with flat absorber (for solar thermal collection) occupies about $39 \%$ of the total system cost, and percentage will decrease when the collector is utilized for certain application due to the costs on extra components [103]. With the advantages of large acceptance angle of CPCs, trackers are not suggested generally only if there is a good tradeoff between the energy collected and trackers.

4) Further improvements of irradiance distribution and temperature on CPC

Irradiance distribution and temperature are the two main factors to be taken into account when designing CPC for some typical applications. For example, when it is integrated with PV system, both of non-uniformity of flux distribution and high temperature result in reduction of electricity generation by PV, but for solar thermal system, high temperature is always required. Improvements on CPCs are encouraged depending on different requirements. Some researchers use adding reflective film [72] or adjusting CPC shape [98] to improve the flux distribution. Many studies $[53,66]$ demonstrate that adding cooling on CPC-PV system (CPVT system) can increase its performance, and removed heat can also be utilized for other thermal applications.

5) Thermal performance and condensation problems of CPC

When CPC is utilized on building facade, its thermal performance should be taken into consideration. In the research by Mallick and Eames [69], CPC was attached single glazing and double glazing respectively to compare their general properties with common glazing in market, which provides a good example of whether it is practicable as building facade. Apart from thermal performance, the condensation is another problem that may affect the performance of the system with CPC, especially for PV. A glass cover is applied to overcome this problem in some researches $[53,66,74]$.

6) Outdoor experiment

According to the summary of literatures, it can be seen that most of experiments were taken indoor by solar simulator. Indoor experiment is a fast and easy way to test CPC performance. However, outdoor experiments are recommended in view of different weather conditions. For some CPC applications, when it is influenced much by diffused sky light, the outdoor experiments may show different results with simulations and indoor test. For example, in a research [102] for solar thermal collector, the outdoor experiments presented that the different cloudy interval causes different performance of whole systems. Therefore, the outdoor experiment is important because it is difficult to analog real weather variations by solar simulator.

\section{Summary}

A comprehensive review of the recent research progress on the compound parabolic concentrator (CPC) has been presented. The concept and design principles of a CPC were introduced. The reviewed literatures mainly cover the period since 2000 and they have been classified according to the structures and applications. The simulation methods that suitable for CPC analysis were demonstrated. A couple of flow charts and tables have been used to give a holistic view of those literatures on CPC and make a clear summarization of those studies. Moreover, some thoughts and outlook have been put forward regarding the published work and 
future research on the CPC.

\section{Acknowledgement}

The authors would like to thank the European Commission for the Marie Curie Fellowship grants (PIIF-GA-2009-253945, PIIF-GA-2010-275038). We would also like to thank the Royal Society and the National Natural Science Foundation of China (NSFC) for an international collaboration grant.

\section{References}

1. Nilsson, J., Optical Design and Characterization of Solar Concentrators for Photovoltaics. 2005, Lund University, Lund Institute of Technology: Lund.

2. Baranov, V.K., Properties of the Parabolico-theoric focons. Opt. Mekh. Prom., 1965. 6: p. 1-5.

3. Baranov, V.K., Parabolotoroidal mirrors as elements of solar energy concentrators. Appl. Sol. Energy, 1966. 2(1): p. 9-12.

4. Ploke, M., Lichtführungseinrichtungen mit starker Konzentrationswirkung (English translation: A light guiding device with strong concentration action). Optik, 1967. 25: p. 31-43.

5. Baranov, V.K., Device for Restricting in one plane the angular aperture of a pencil of rays from a light source (in Russian). Russian certificate of authorship 200530, 1967.

6. Baranov, V., K., Melnikov, G. K., Study of the illumination characteristics of hollow focons. Sov. J. Opt. Technol., 1966. 33: p. 408-411.

7. Hinterberger, H., Winston, R., Efficient light coupler for threshold Čerenkov counters. Review of Scientific Instruments, 1966. 37: p. 1094-1095.

8. Hinterberger, H., Winston, R., Gas Čerenkov counter with optimized light-collecting efficiency. High Energy Phys., 1966: p. 205-206.

9. Ploke, M., Axially Symmetrical Light Guide Arrangement. 1969, German patent application No. 14722679.

10. Winston, R., Principles of solar concentrators of a novel design. Sol. Energy, 1974. 16: p. 89-95.

11. Winston, R., Hinterberger, H. , Principles of Cylindrical concentrators for solar energy. Sol. Energy, 1975. 17: p. 255-258.

12. Rabl, A., Winston, R., Ideal concentrators for finite sorces and restricted exit angles. Appl. Opt., 1976. 15: p. 2880-2883.

13. Harper, D.A., Hildebrand, R. H., Pernlic, R., Platt, S. R., Heat trap: An optimized far infrared field optics system. Appl. Opt., 1976. 15: p. 53-60.

14. Baylor, D.A., Fettiplace, R., Light and photon capture in turtle receptors. J. Physiol., 1975. 248 : p. 433-464.

15. Levi-Setti, R., Park, D. A., Winston, R., The corneal cones of Limulus as optimized light collectors. Nature (London), 1975. 253: p. 115-116.

16. Winston, R., Enoch, J. M., Retinal cone receptor as an ideal light collector. J. Opt. Soc. Amer., 1971. 61: p. 1120-1121.

17. Willer, U., C. Romano, and W. Schade. Compact gas sensing system based on mid-infrared LED and resonant detection with quartz tuning fork. in Lasers and Electro-Optics, 2009 and 2009 Conference on Quantum electronics and Laser Science Conference. CLEO/QELS 2009. Conference on. 2009.

18. Wang, K., et al., High-speed duplex optical wireless communication system for indoor personal area networks. Optics Express, 2010. 18(24): p. 25199-25216.

19. Keränen, K., et al., Infrared temperature sensor system for mobile devices. Sensors and Actuators A: Physical, 2010. 158(1): p. 161-167.

20. Gandia, L.M., G. Arzamedi, and P.M. Dieguez, 4.3.1 Redox Cycles, in Renewable Hydrogen Technologies - Production, Purification, Storage, Applications and Safety. 2013, Elsevier.

21. Saitoh, T.S. and J. Takahashi. Cooling power enhancement for 2-D and 3-D CPC sky radiators. in Energy Conversion Engineering Conference, 2002. IECEC '02. 2002 37th Intersociety. 2002.

22. Nakamaru, F., Y. Matsumoto, and A. Nakazono, Novel high-efficiency concentrator for optical fiber communication. Photonics Technology Letters, IEEE, 2002. 14(7): p. 953-955.

23. Liang, D. and R. Pereira, Diode pumping of a solid-state laser rod by a two-dimensional CPCelliptical cavity with intervening optics. Optics Communications, 2007. 275(1): p. 104-115.

24. Almeida, J., D. Liang, and E. Guillot, Improvement in solar-pumped Nd:YAG laser beam brightness. Optics \& Laser Technology, 2012. 44(7): p. 2115-2119. 
25. Xing-Jie, Y., et al., LED-Based Projection Systems. Display Technology, Journal of, 2007. 3(3): p.

26. Chenhui, P., et al. A high power light emitting diode module for projection display application. in Electronic Packaging Technology \& High Density Packaging (ICEPT-HDP), 2010 11th International Conference on. 2010.

27. Chenhui, P., et al. Light collection systems for multiple LED arrays. in Advances in Optoelectronics and Micro/Nano-Optics (AOM), 2010 OSA-IEEE-COS. 2010.

28. Aoki, M., et al., Passive imaging and emissivity measurement with a $4 K$-cryocooled terahertz photoconductive detector. IEICE Electronics Express, 2012. 9(5): p. 333-338.

29. Aoki, M., et al., Angle dependent condensing efficiency of Winston cone in terahertz region. Infrared Physics \& Technology, 2013. 56: p. 8-11.

30. Grossman, E.N., O.D. Friedman, and A.O. Nelson, Non-Imaging Winston Cone Concentrators for Submillimeter-Wave, Overmoded Waveguide. Terahertz Science and Technology, IEEE Transactions on, 2014. 4(1): p. 65-74.

31. Chemisana, D., Building Integrated Concentrating Photovoltaics: A review. Renewable and Sustainable Energy Reviews, 2011. 15(1): p. 603-611.

32. Sharaf, O.Z. and M.F. Orhan, Concentrated photovoltaic thermal (CPVT) solar collector systems: Part I - Fundamentals, design considerations and current technologies. Renewable and Sustainable Energy Reviews, 2015. 50: p. 1500-1565.

33. Sharaf, O.Z. and M.F. Orhan, Concentrated photovoltaic thermal (CPVT) solar collector systems: Part II - Implemented systems, performance assessment, and future directions. Renewable and Sustainable Energy Reviews, 2015. 50: p. 1566-1633.

34. Norton, B., et al., Enhancing the performance of building integrated photovoltaics. Solar Energy, 2011. 85(8): p. 1629-1664.

35. Grágeda, M., et al., Review and multi-criteria assessment of solar energy projects in Chile. Renewable and Sustainable Energy Reviews, 2016. 59: p. 583-596.

36. Smith, E.H., 12.3.5 Atria, in Mechanical Engineer's Reference Book (12th Edition). 1998, Elsevier: UK.

37. Selvakumar, N. and H.C. Barshilia, Review of physical vapor deposited (PVD) spectrally selective coatings for mid-and high-temperature solar thermal applications. Solar Energy Materials and Solar Cells, 2012. 98: p. 1-23.

38. Kalogirou, S.A., Solar thermal collectors and applications. Progress in Energy and Combustion Science, 2004. 30(3): p. 231-295.

39. Colangelo, G., et al., Innovation in flat solar thermal collectors: A review of the last ten years experimental results. Renewable and Sustainable Energy Reviews, 2016. 57: p. 1141-1159.

40. Singh, H. and P.C. Eames, A review of natural convective heat transfer correlations in rectangular cross-section cavities and their potential applications to compound parabolic concentrating (CPC) solar collector cavities. Applied Thermal Engineering, 2011. 31(14-15): p. 2186-2196.

41. Gallagher, J., Nonimaging Optics in Solar Energy. Nonimaging Optics in Solar Energy. 2008: Morgan \& Claypool. 1-120.

42. Welford, W.T. and R. Winston, High Collection Nonimaging Optics. 1989: Academic Press. 1-7.

43. Winston, R. and W.T. Welford, Design of nonimaging concentrators as second stages in tandem with image-forming first-stage concentrators. Applied Optics, 1980. 19(3): p. 347-351.

44. Winston, R., J.C. Miñano, and P. Benítez, Nonimaging Optics. 2005, Burlington: Academic Press.

45. Moore, J.H., et al., 4.3.3 Lenses and Lens Systems, in Building Scientific Apparatus (4th Edition). 2009, Cambridge University Press: USA.

46. Winston, R., Radiant Energy Concentration. 1976, U.S. letters patent 3923381.

47. Winston, R., Radiant Energy Concentration. 1977, U.S. letters patent 4003638.

48. Winston, R., Cylindrical Concentrators for Solar Energy. 1977, U.S. letters patent 4002499.

49. Winston, R. and W. Zhang, Pushing concentration of stationary solar concentrators to the limit. Optics Express, 2010. 18(S1): p. A64-A72.

50. Timinger, A., et al., Faceted concentrators optimized for homogeneous radiation. Applied Optics, 2000. 39(7): p. 1152-1158.

51. van Dijk, L., et al., 3D-printed concentrator arrays for external light trapping on thin film solar cells. Solar Energy Materials and Solar Cells, 2015. 139: p. 19-26. 
52. Cooper, T., et al., Performance of compound parabolic concentrators with polygonal apertures.

53. Bahaidarah, H., B. Tanweer, and P. Gandhidasan. Performance analysis of a low concentrating PV-CPC system. in Photovoltaic Specialists Conference (PVSC), 2013 IEEE 39th. 2013.

54. Winston, R., Dielectric compound parabolic concentrators. Applied Optics, 1976. 15(2): p. 291-292.

55. Welford, W.T. and R. Winston, The optics of nonimaging concentrators - Light and solar energy. 1978.

56. Rabl, A., Optical and thermal properties of Compound Parabolic Concentrators. Solar Energy, 1976. 18(6): p. 497-511.

57. Rabl, A., Comparison of Solar Concentrators. Solar energy, 1975. 18(2): p. 93-111.

58. Rabl, A., Solar concentrators with maximal concentration for cylindrical absorbers. Applied Optics, 1976. 15(7): p. 1871-1873.

59. Su, Y., et al., Radiance/Pmap simulation of a novel lens-walled compound parabolic concentrator (lens-walled CPC). Energy Procedia, 2012. 14: p. 572-577.

60. Su, Y., S.B. Riffat, and G. Pei, Comparative study on annual solar energy collection of a novel lens-walled compound parabolic concentrator (lens-walled CPC). Sustainable Cities and Society, 2012. 4: p. 35-40.

61. Guiqiang, L., et al., Experiment and simulation study on the flux distribution of lens-walled compound parabolic concentrator compared with mirror compound parabolic concentrator. Energy, 2013. 58: p. 398-403.

62. Guiqiang, L., et al., Design and investigation of a novel lens-walled compound parabolic concentrator with air gap. Applied Energy, 2014. 125: p. 21-27.

63. Li, G., et al., Optical evaluation of a novel static incorporated compound parabolic concentrator with photovoltaic/thermal system and preliminary experiment. Energy Conversion and Management, 2014. 85: p. 204-211.

64. Pei, G., Li, G., Su, Y., Ji, J., Solar inner wall lens type compound parabolic concentrator with air interlayer. 2013, Patent Number $\mathrm{CH} 203464513$.

65. Sun, J. and M. Shi. Experimental Study on A Concentrating Solar Photovoltaic/Thermal System. in Power and Energy Engineering Conference (APPEEC), 2010 Asia-Pacific. 2010.

66. Bahaidarah, H.M., et al., Experimental and numerical study on non-concentrating and symmetric unglazed compound parabolic photovoltaic concentration systems. Applied Energy, 2014. 136: p. 527-536.

67. Mallick, T.K., P.C. Eames, and B. Norton, Non-concentrating and asymmetric compound parabolic concentrating building façade integrated photovoltaics: An experimental comparison. Solar Energy, 2006. 80(7): p. 834-849.

68. Arashi, H., et al. Highly concentrated solar energy transmission through an optical fiber coupled with CPC. in Energy Conversion Engineering Conference, 1997. IECEC-97., Proceedings of the 32nd Intersociety. 1997.

69. Mallick, T.K. and P.C. Eames, Design and fabrication of low concentrating second generation PRIDE concentrator. Solar Energy Materials and Solar Cells, 2007. 91(7): p. 597-608.

70. Walze, G., et al., Combination of microstructures and optically functional coatings for solar control glazing. Solar Energy Materials and Solar Cells, 2005. 89(2-3): p. 233-248.

71. Baig, H., et al., Performance analysis of a dielectric based 3D building integrated concentrating photovoltaic system. Solar Energy, 2014. 103: p. 525-540.

72. Baig, H., et al., Enhancing performance of a linear dielectric based concentrating photovoltaic system using a reflective film along the edge. Energy, 2014. 73: p. 177-191.

73. Arnaoutakis, G.E., et al., Enhanced energy conversion of up-conversion solar cells by the integration of compound parabolic concentrating optics. Solar Energy Materials and Solar Cells, 2015. 140: p. 217-223.

74. Sarmah, N., B.S. Richards, and T.K. Mallick, Design, development and indoor performance analysis of a low concentrating dielectric photovoltaic module. Solar Energy, 2014. 103: p. 390-401.

75. Baig, $\mathrm{H}$. , et al., Numerical modelling and experimental validation of a low concentrating photovoltaic system. Solar Energy Materials and Solar Cells, 2013. 113: p. 201-219.

76. Baig, H., N. Sellami, and T.K. Mallick, Trapping light escaping from the edges of the optical element in a Concentrating Photovoltaic system. Energy Conversion and Management, 2015. 
90: p. 238-246.

77. Stine, W.B. and M.A. Geyer. PowerFromTheSun.net. 2001; Available from: www.powerfromthesun.net/.

78. Yu, X. and Y. Su, A discussion of inner south projection angle for performance analysis of dielectric compound parabolic concentrator. Solar Energy, 2015. 113: p. 101-113.

79. Madala, S. and R.F. Boehm, A review of nonimaging solar concentrators for stationary and passive tracking applications. Renewable and Sustainable Energy Reviews, 2017. 71: p. 309322.

80. SolarPowerEurope, Globle market outlook for solar power 2015-2019, S. Europe, Editor. 2015, SolarPower Europe, the new EPIA (European Photovoltaic Industry Association): Belgium.

81. Meza, E., Global CPV capacity expected to reach $1 \mathrm{GW}$ by 2020. 2014, PV magazine.

82. Jaaz, A.H., et al., Design and development of compound parabolic concentrating for photovoltaic solar collector: Review. Renewable and Sustainable Energy Reviews, 2017. 76: p. 1108-1121.

83. Karathanassis, I.K., et al., Design and experimental evaluation of a parabolic-trough concentrating photovoltaic/thermal (CPVT) system with high-efficiency cooling. Renewable Energy, 2017. 101: p. 467-483.

84. Grasso, G., et al., Competitiveness of stationary planar low concentration photovoltaic modules using silicon cells: A focus on concentrating optics. Solar Energy, 2012. 86(6): p. 1725-1732.

85. Chen, L.L.C., Stationary photovoltaic array module design for solar electric power generation systems. 2003, Google Patents.

86. Chen, L.L.C., Photovoltaic array module design for solar electric power generation systems. 2004, Google Patents.

87. Chong, K.-K., et al., Design and development in optics of concentrator photovoltaic system. Renewable and Sustainable Energy Reviews, 2013. 19: p. 598-612.

88. Li, G., et al., Outdoor overall performance of a novel air-gap-lens-walled compound parabolic concentrator (ALCPC) incorporated with photovoltaic/thermal system. Applied Energy, 2015. 144: p. 214-223.

89. Li, G., et al., Numerical and experimental study on a PV/T system with static miniature solar concentrator. Solar Energy, 2015. 120: p. 565-574.

90. Sellami, N. and T.K. Mallick, Optical efficiency study of PV Crossed Compound Parabolic Concentrator. Applied Energy, 2013. 102: p. 868-876.

91. Sellami, N., T.K. Mallick, and D.A. McNeil, Optical characterisation of 3-D static solar concentrator. Energy Conversion and Management, 2012. 64: p. 579-586.

92. Li, W., et al., Coupled Simulation of Performance of a Crossed Compound Parabolic Concentrator with Solar Cell. Energy Procedia, 2015. 75: p. 325-330.

93. Gang, P., et al., Preliminary Ray Tracing and Experimental Study on the Effect of Mirror Coating on the Optical Efficiency of a Solid Dielectric Compound Parabolic Concentrator. Energies, 2012. 5(9): p. 3627-3639.

94. Lamnatou, C., et al., Life cycle energy analysis and embodied carbon of a linear dielectricbased concentrating photovoltaic appropriate for building-integrated applications. Energy and Buildings, 2015. 107: p. 366-375.

95. Yew, T.-K., K.-K. Chong, and B.-H. Lim, Performance study of crossed compound parabolic concentrator as secondary optics in non-imaging dish concentrator for the application of dense-array concentrator photovoltaic system. Solar Energy, 2015. 120: p. 296-309.

96. Chong, K.-K., et al., Prototype of Dense-array Concentrator Photovoltaic System Using Nonimaging Dish Concentrators and Cross Compound Parabolic Concentrator. Energy Procedia, 2017. 105: p. 131-136.

97. Andreev, V.M., et al. High-efficiency (24.6\% AM 0) LPE grown AlGaAs/GaAs concentrator solar cells and modules. in Photovoltaic Energy Conversion, 1994., Conference Record of the Twenty Fourth. IEEE Photovoltaic Specialists Conference - 1994, 1994 IEEE First World Conference on. 1994.

98. Tsai, C.-Y., Enhanced irradiance distribution on solar cell using optimized variable-focusparabolic concentrator. Optics Communications, 2013. 305: p. 221-227.

99. Abu-Bakar, S.H., et al., Rotationally asymmetrical compound parabolic concentrator for concentrating photovoltaic applications. Applied Energy, 2014. 136: p. 363-372. 
100. Abu-Bakar, S.H., et al., Performance analysis of a novel rotationally asymmetrical compound parabolic concentrator. Applied Energy, 2015. 154: p. 221-231.

101. Santos-González, I., et al., Numerical modeling and experimental analysis of the thermal performance of a Compound Parabolic Concentrator. Applied Thermal Engineering, 2017. 114: p. 1152-1160.

102. Ortiz-Rivera, E.I. and L.I. Feliciano-Cruz. Performance evaluation and simulation of a solar thermal power plant. in Energy Conversion Congress and Exposition, 2009. ECCE 2009. IEEE. 2009.

103. Al-Ghasem, A., G. Tashtoush, and M. Aladeemy. Experimental study of tracking 2-D Compound Parabolic Concentrator (CPC) with flat plate absorber. in Renewable Energy Research and Applications (ICRERA), 2013 International Conference on. 2013.

104. Mishra, R.K., V. Garg, and G.N. Tiwari, Energy matrices of U-shaped evacuated tubular collector (ETC) integrated with compound parabolic concentrator (CPC). Solar Energy, 2017. 153: p. 531-539.

105. Ratismith, W., A. Inthongkhum, and J. Briggs, Two non-tracking solar collectors: Design criteria and performance analysis. Applied Energy, 2014. 131: p. 201-210.

106. Canaff, M. and W. Ratismith. High productivity non-tracking solar collectors for process heat applications. in Environment and Electrical Engineering (EEEIC), 2015 IEEE 15th International Conference on. 2015.

107. Abdullahi, B., R.K. Al-dadah, and S. Mouhmud, Optical Performance of Double Receiver Compound Parabolic Concentrator. Energy Procedia, 2014. 61: p. 2625-2628.

108. Abdullahi, B., et al., Optical and thermal performance of double receiver compound parabolic concentrator. Applied Energy, 2015. 159: p. 1-10.

109. Gang, P., et al., Experimental study and exergetic analysis of a CPC-type solar water heater system using higher-temperature circulation in winter. Solar Energy, 2012. 86(5): p. 12801286.

110. Xu, R.J., et al., Experimental investigation of a solar collector integrated with a pulsating heat pipe and a compound parabolic concentrator. Energy Conversion and Management, 2017. 148: p. 68-77.

111. Wang, Y., et al., Performance analysis of a novel sun-tracking CPC heat pipe evacuated tubular collector. Applied Thermal Engineering, 2015. 87: p. 381-388.

112. Ulavi, T., J.H. Davidson, and T. Herbrink. Analysis of a hybrid PV/T Concept based on wavelength selective films. in ASME 2013 7th International Conference on Energy Sustainability. 2013. Minneapolis, Minnesota, USA, July 14-19, 2013.

113. Yanhua, L., et al. Thermal performance analysis of linear fresnel reflector concentrator with a compound parabolic cavity absorber. in Materials for Renewable Energy \& Environment (ICMREE), 2011 International Conference on. 2011.

114. Chaitanya Prasad, G.S., K.S. Reddy, and T. Sundararajan, Optimization of solar linear Fresnel reflector system with secondary concentrator for uniform flux distribution over absorber tube. Solar Energy, 2017. 150: p. 1-12.

115. Baljit, S.S.S., et al., Mathematical modelling of a dual-fluid concentrating photovoltaicthermal (PV-T) solar collector. Renewable Energy, 2017. 114: p. 1258-1271.

116. Ma, X., H. Zheng, and Z. Chen, An investigation on a compound cylindrical solar concentrator (CCSC). Applied Thermal Engineering, 2017. 120: p. 719-727.

117. Smyth, M., et al., Experimental comparison of alternative convection suppression arrangements for concentrating integral collector storage solar water heaters. Solar Energy, 2005. 78(2): p. 223-233.

118. Antonelli, M., et al., Electrical production of a small size Concentrated Solar Power plant with compound parabolic collectors. Renewable Energy, 2015. 83: p. 1110-1118.

119. Tiwari, D., et al., Energy and exergy analysis of solar driven recuperated organic Rankine cycle using glazed reverse absorber conventional compound parabolic concentrator (GRACCPC) system. Solar Energy, 2017. 155: p. 1431-1442.

120. Singh, D.B. and G.N. Tiwari, Performance analysis of basin type solar stills integrated with $N$ identical photovoltaic thermal (PVT) compound parabolic concentrator (CPC) collectors: A comparative study. Solar Energy, 2017. 142: p. 144-158.

121. Singh, D.B. and G.N. Tiwari, Exergoeconomic, enviroeconomic and productivity analyses of basin type solar stills by incorporating $N$ identical PVT compound parabolic concentrator 
collectors: A comparative study. Energy Conversion and Management, 2017. 135: p. 129-147.

122. Nishi, Y. and T. Sema, Estimation of exergy efficiency of compound parabolic concentrator under time-varying cloud cover condition. Solar Energy, 2013. 98, Part C: p. 341-348.

123. Elashmawy, M., An experimental investigation of a parabolic concentrator solar tracking system integrated with a tubular solar still. Desalination, 2017. 411: p. 1-8.

124. Noyes, R., 7.15 Solar Energy, in Unit Operations in Environmental Engineering. 1994, William Andrew Publishing/Noyes: USA.

125. Yu, X., et al., A study on use of miniature dielectric compound parabolic concentrator (dCPC) for daylighting control application. Building and Environment, 2014. 74: p. 75-85.

126. Ulavi, T., T. Hebrink, and J.H. Davidson, Analysis of a hybrid solar window for building integration. Solar Energy, 2014. 105: p. 290-302.

127. Ulavi, T., T. Hebrink, and J.H. Davidson, Analysis of a Hybrid Solar Window for Building Integration. Energy Procedia, 2014. 57: p. 1941-1950.

128. Zacharopoulos, A., et al., Linear dielectric non-imaging concentrating covers for PV integrated building facades. Solar Energy, 2000. 68(5): p. 439-452.

129. Mallick, T.K., et al., The design and experimental characterisation of an asymmetric compound parabolic photovoltaic concentrator for building façade integration in the UK. Solar Energy, 2004. 77(3): p. 319-327.

130. Sarmah, N. and T.K. Mallick, Design, fabrication and outdoor performance analysis of a low concentrating photovoltaic system. Solar Energy, 2015. 112: p. 361-372.

131. Taengchum, T., et al., Tracing of daylight through circular light pipes with anidolic concentrators. Solar Energy, 2014. 110: p. 818-829.

132. Wittkopf, S., et al., Ray tracing study for non-imaging daylight collectors. Solar Energy, 2010. 84(6): p. 986-996.

133. Xue, X., et al., Study of a novel sunlight concentrating and optical fibre guiding system. Solar Energy, 2011. 85(7): p. 1364-1370.

134. Ullah, I. and S. Shin, Highly concentrated optical fiber-based daylighting systems for multifloor office buildings. Energy and Buildings, 2014. 72: p. 246-261.

135. Zhang, T.C., et al., 3.4.1.2 Compound Parabolic Concentrator (CPC) System, in Nanotechnologies for Water Environment Applications. 2009, American Society of Civil Engineers (ASCE).

136. Tanveer, M. and G. Tezcanli Guyer, Solar assisted photo degradation of wastewater by compound parabolic collectors: Review of design and operational parameters.

Renewable and Sustainable Energy Reviews, 2013. 24: p. 534-543. 


\section{'A review on the recent research progress in the compound parabolic concentrator (CPC) for solar energy applications'}

\section{List of Figures}

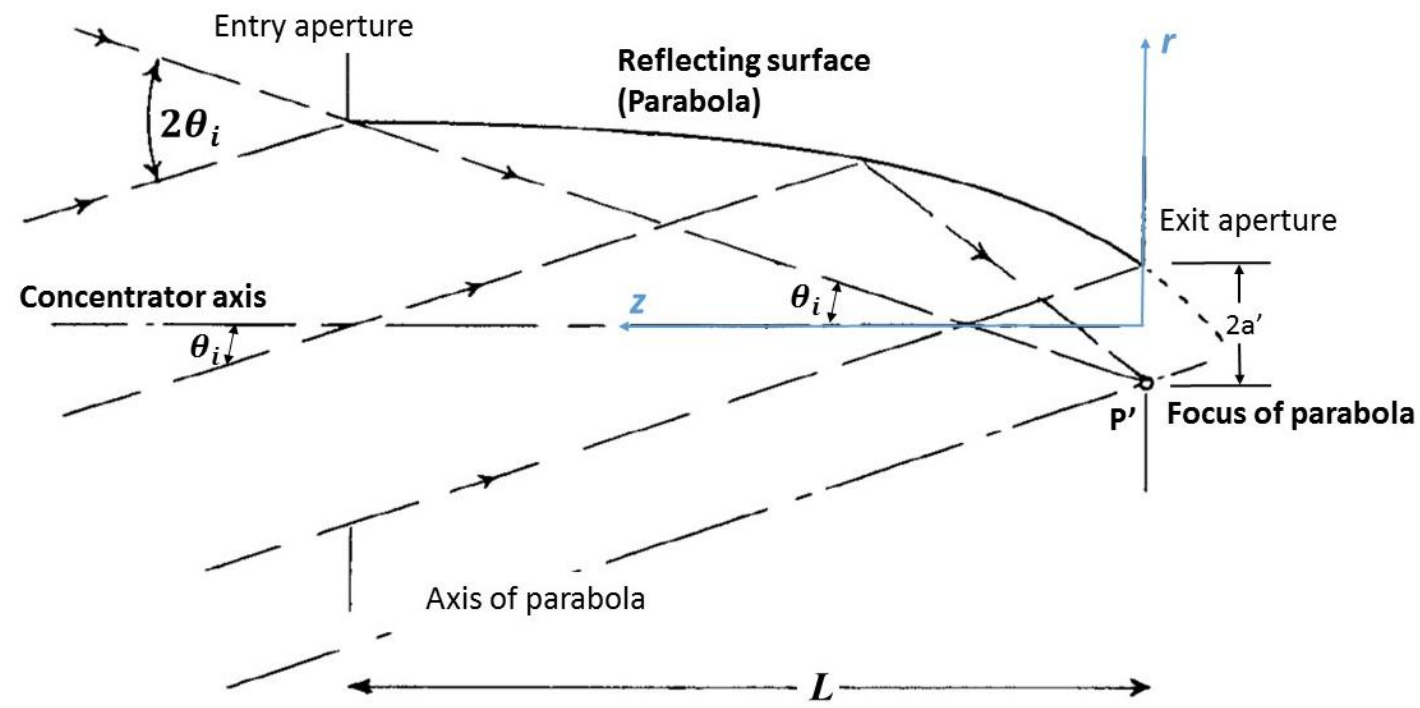

Fig. 1. Construction of the CPC profile from the edge-ray principle [31]

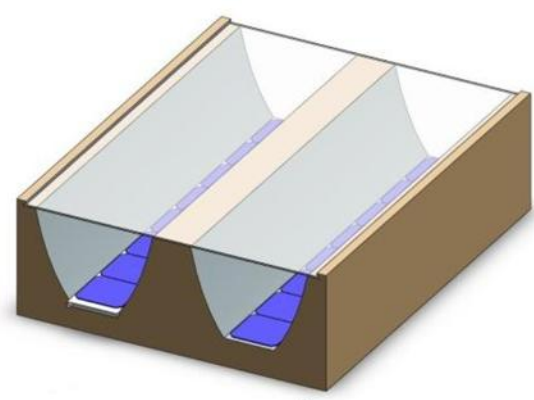

a)

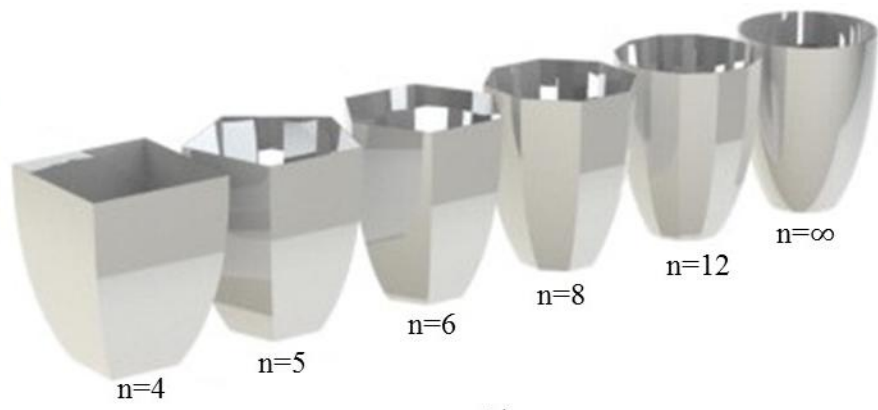

b)

Fig. 2. Example of 2D and 3D CPCs, a) 2D trough CPC with a glass on top and PV on bottom [53]; b) 3D CPCs with polygonal apertures of $4,5,6,8,12$ sides and revolved CPC $(n=\infty)$ [52] 


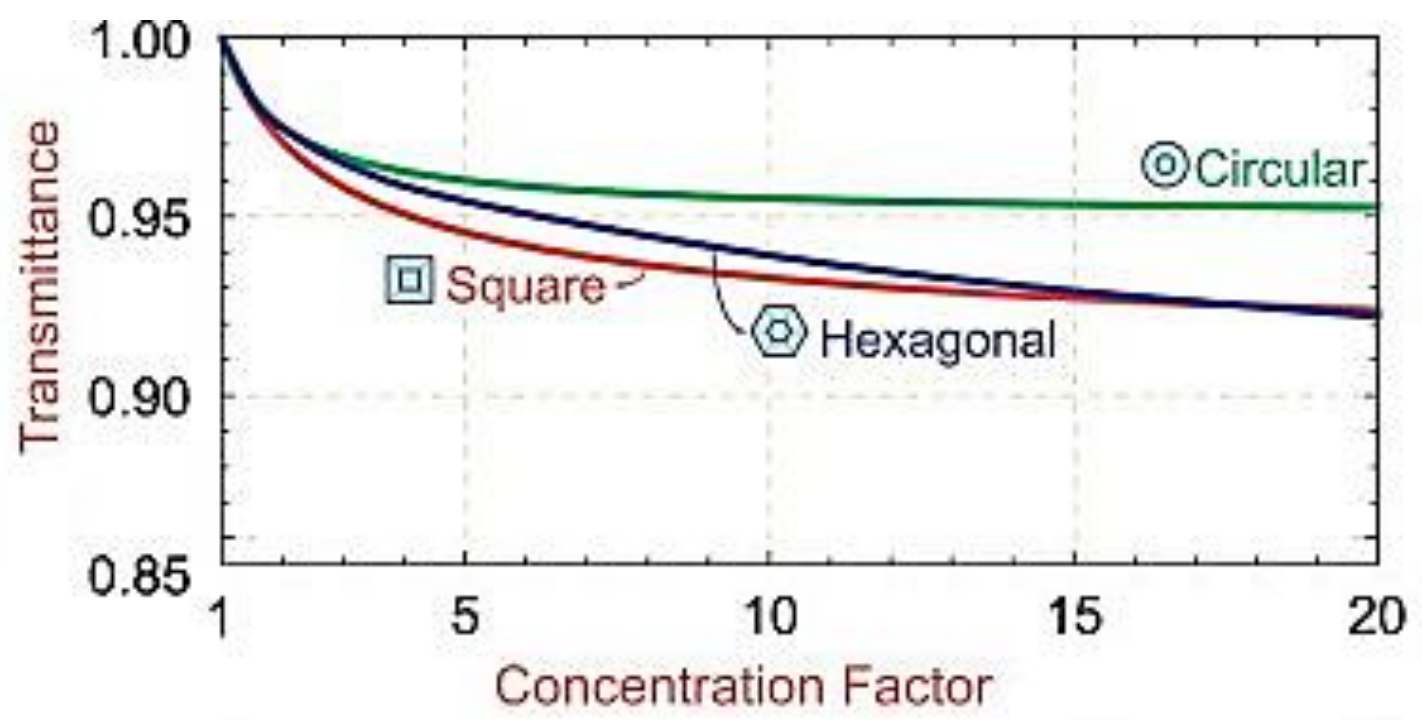

Fig. 3. Plot of the transmittance as a function of concentration ratio (factor) for square, hexagonal, and circular 3D CPCs with reflectance of $95 \%$ of surface. [51]

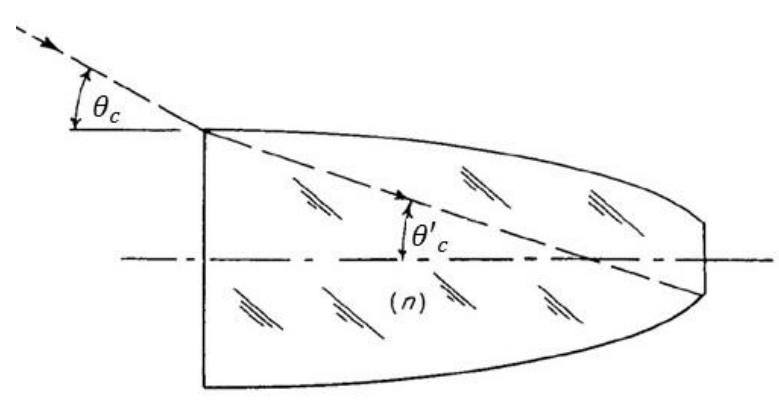

(a)

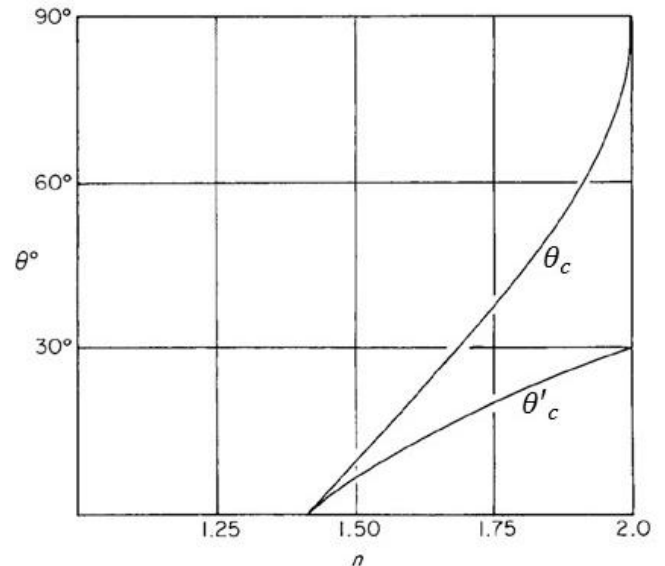

(b)

Fig. 4. a) A dielectric-filled CPC with $\theta^{\prime}{ }_{c}$ of $18^{\circ}$ and a refractive index of 1.5 ; b) The maximum internal and external acceptance angles for a dielectric-filled CPC with total internal reflection, as functions of the refractive index [55] 


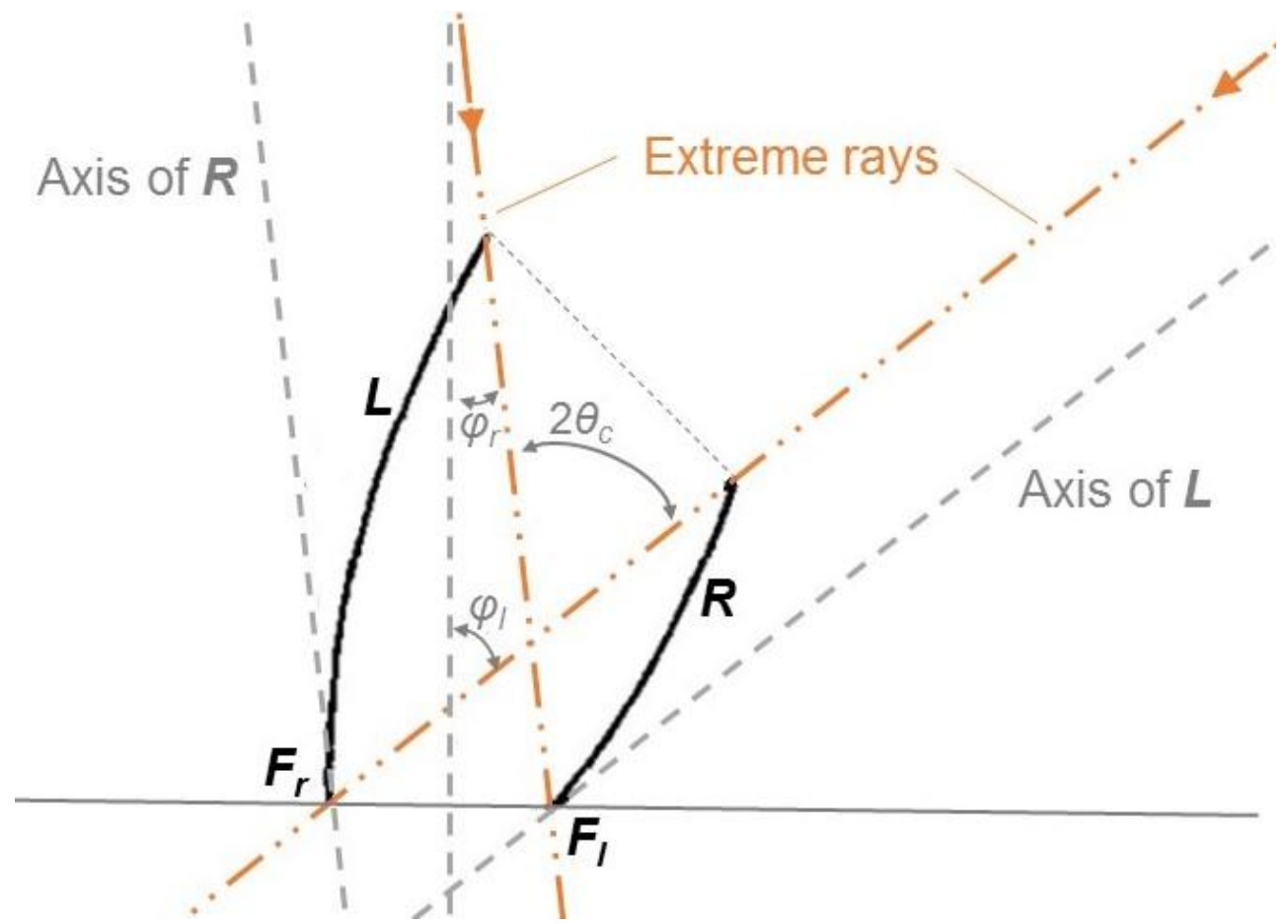

Fig. 5. Asymmetric ideal CPC ( $L, R$ : parabolas; $F_{i}$ focus of $L ; F_{r}$ : focus of $R$; acceptance angle: $2 \vartheta_{c}$; $\varphi_{r}, \varphi_{1}$ : subtended angle of parabola axes) [57]

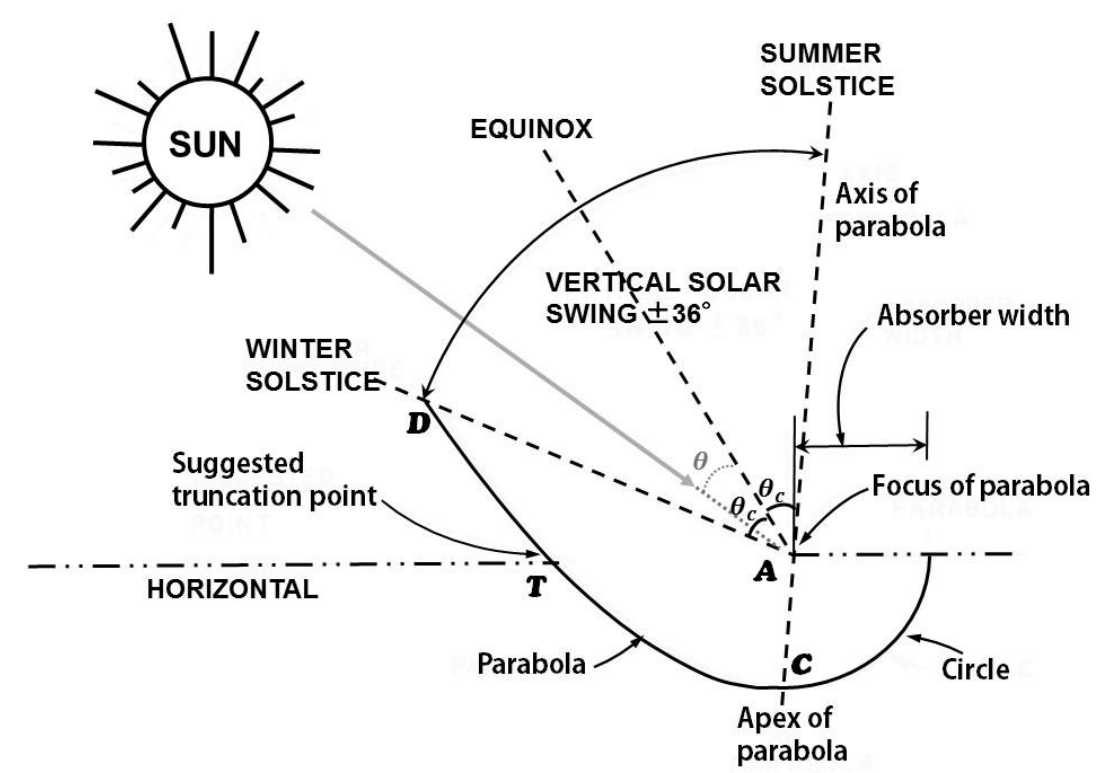

Fig. 6. Section view of a stationary "Sea shell" collector with the maximum output in summer [57] 

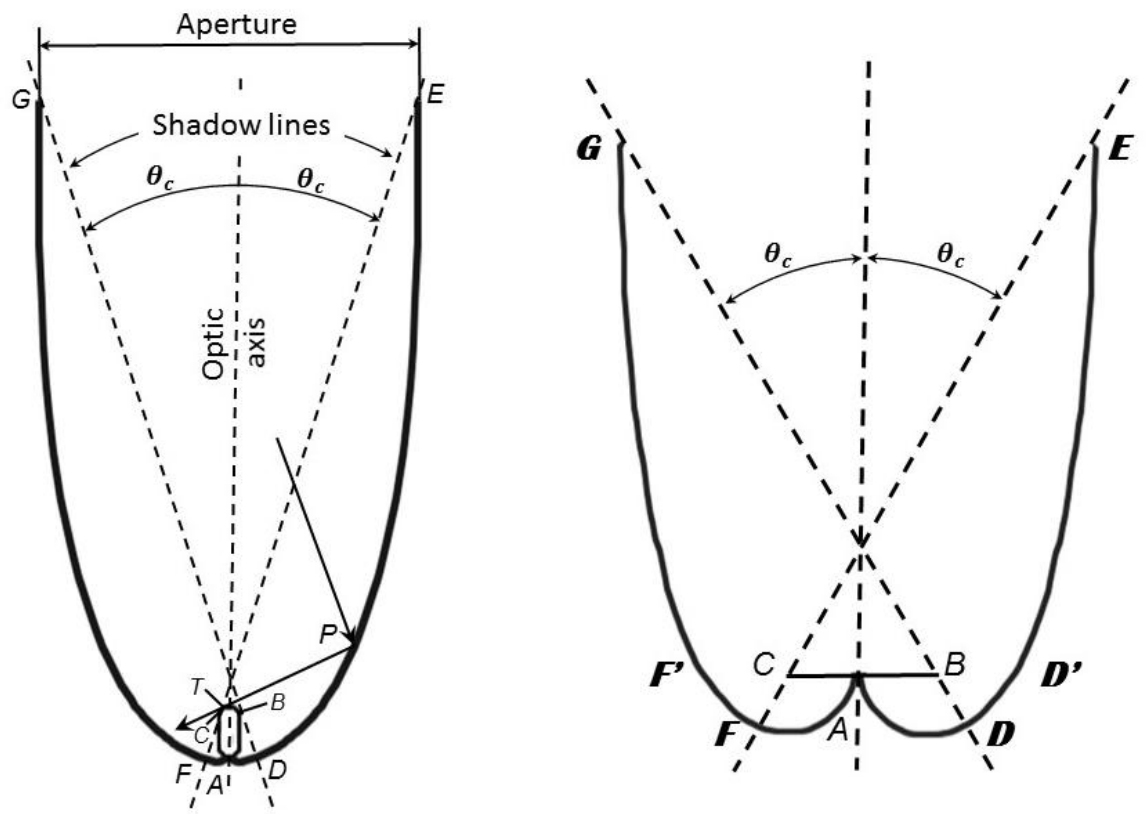

Fig. 7. Section view of an ideal cylindrical concentrator with arbitrary absorber shape, a) concentrator with pipe-shaped absorber; b) concentrator with flat absorber [57]

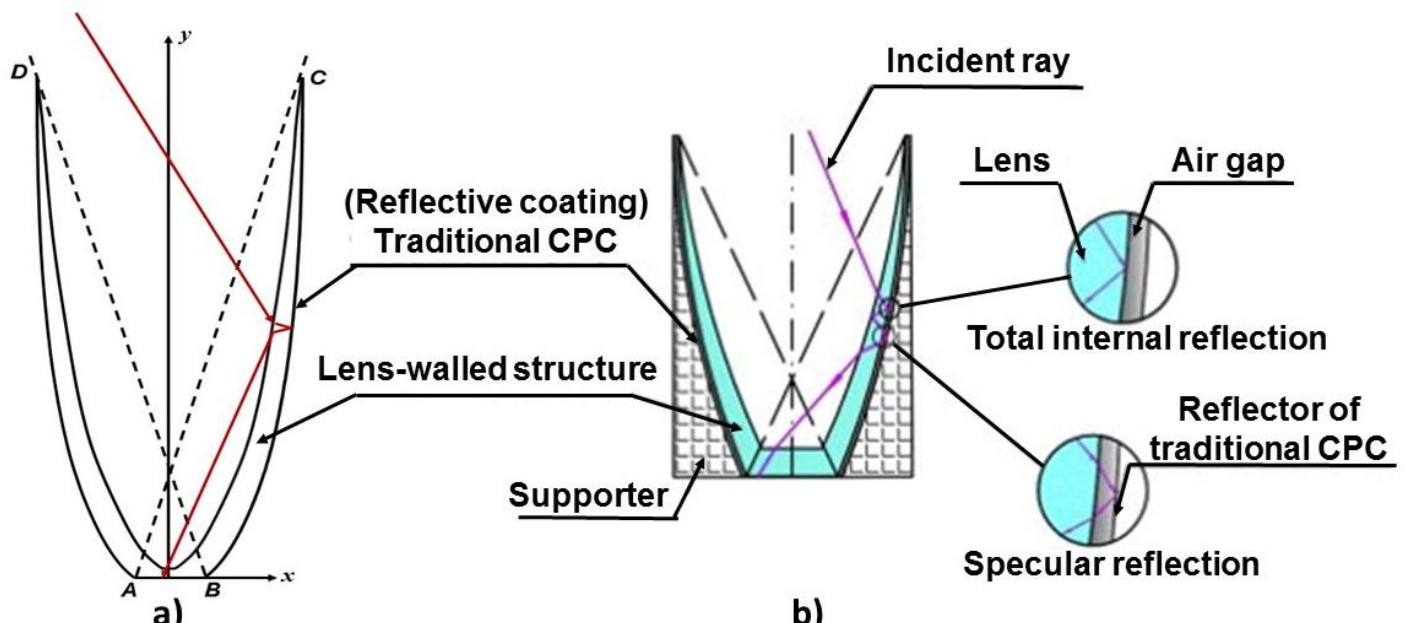

b)

Fig. 8. Section view of lens-walled CPC, a) conventional lens-walled CPC; b) lens-walled CPC with air gap $[61,63]$ 


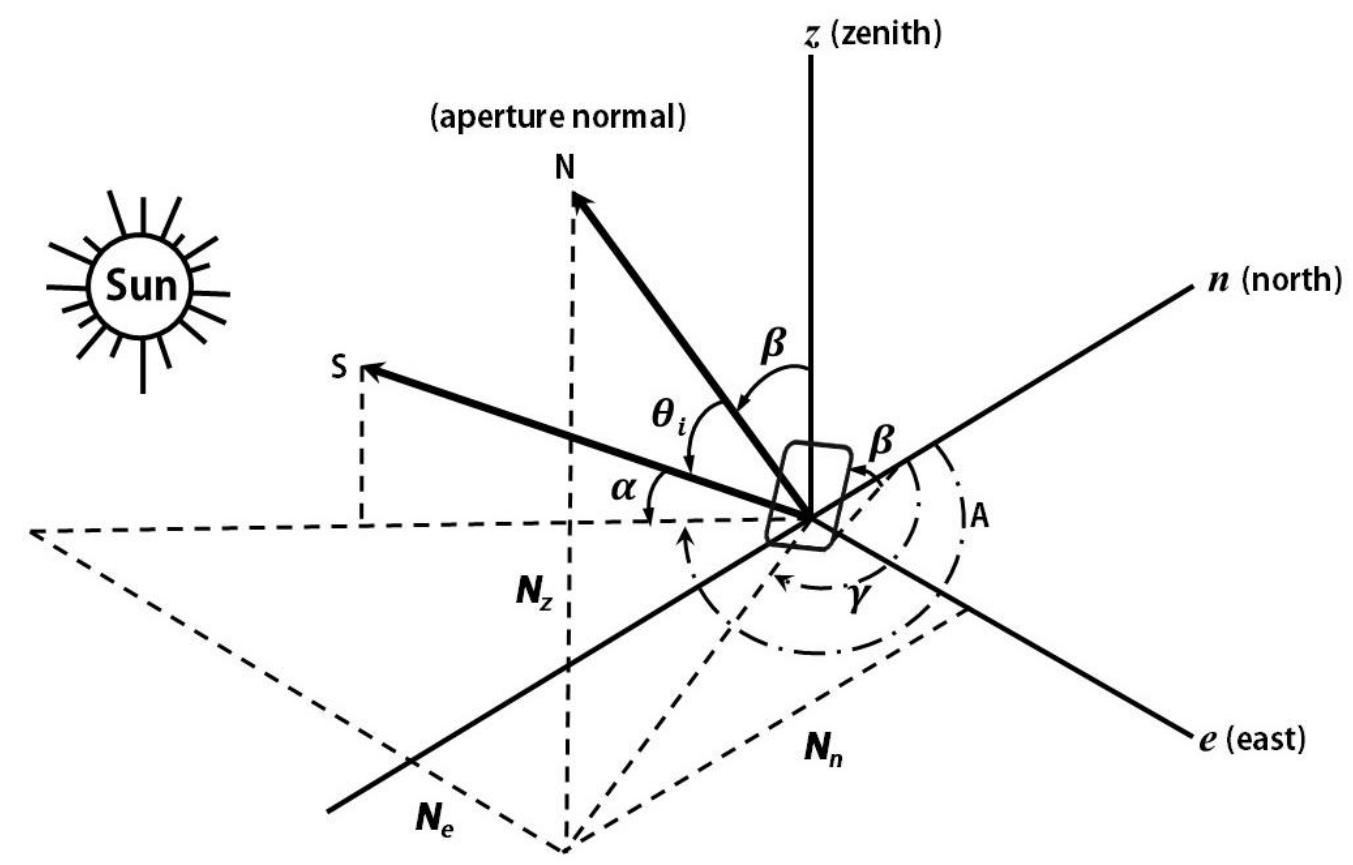

Fig. 9. A fixed aperture with its orientation defined by the tilt angle $(\beta)$ and the aperture azimuth angle $(\gamma)$. $\mathrm{N}$ is the aperture normal; vector $\mathrm{S}$ is a ray of the direct solar radiation; $\alpha$ is the angle of solar radiation to the earth's surface; $A$ is the solar azimuth; $\theta_{i}$ is the angle of incidence, which is the angle between the ray and the aperture normal; the direction cosines of $\mathrm{N}$ along the $\mathrm{z}$, $\mathrm{e}$ and $n$ axes respectively as $N_{z}, N_{e}$ and $N_{n}[77]$.

\section{CPC literatures categorized by application}

\begin{tabular}{|c|c|c|c|}
\hline CPC in Photovoltaic System & CPC in Solar Thermal & CPC in Daylighting & Others \\
\hline $\begin{array}{l}\text { - } 2 \mathrm{D} \text { trough } \mathrm{CPC} \\
\text { - } \text { Lens-walled CPC } \\
\text { - } \text { Crossed CPC (CCPC) } \\
\text { - } 3 \text { D revolved CPC } \\
\text { - } \text { VPF and RACPC }\end{array}$ & $\begin{array}{l}\text { - CPC with tubular } \\
\text { absorber } \\
\text { - CPC in Integrated } \\
\text { collector storage solar } \\
\text { water heater (ICSSWH) } \\
\text { - CPC in Organic Rankine } \\
\text { Cycle } \\
\text { - CPC in water steam } \\
\text { generation and } \\
\text { distillation system } \\
\text { - CPC in soil heating }\end{array}$ & $\begin{array}{l}\text { - CPC in daylighting } \\
\text { control } \\
\text { - CPC in PRIDE } \\
\text { - CPC in anidolic } \\
\text { daylighting system } \\
\text { and light pipe } \\
\text { - CPC in optical fibre } \\
\text { guiding system }\end{array}$ & $\begin{array}{l}\text { - CPC in photocatalytic } \\
\text { water purification } \\
\text { - } \mathrm{CPC} \text { in terahertz (THz) } \\
\text { technology } \\
\text { - } \text { CPC in overmoded } \\
\text { waveguide } \\
\text { - CPC in p-i-n } \\
\text { photodiode } \\
\text { - CPC in lasers } \\
\text { - } \mathrm{CPC} \text { in LED projector }\end{array}$ \\
\hline
\end{tabular}

Fig. 10. Flow chart of Section 3 


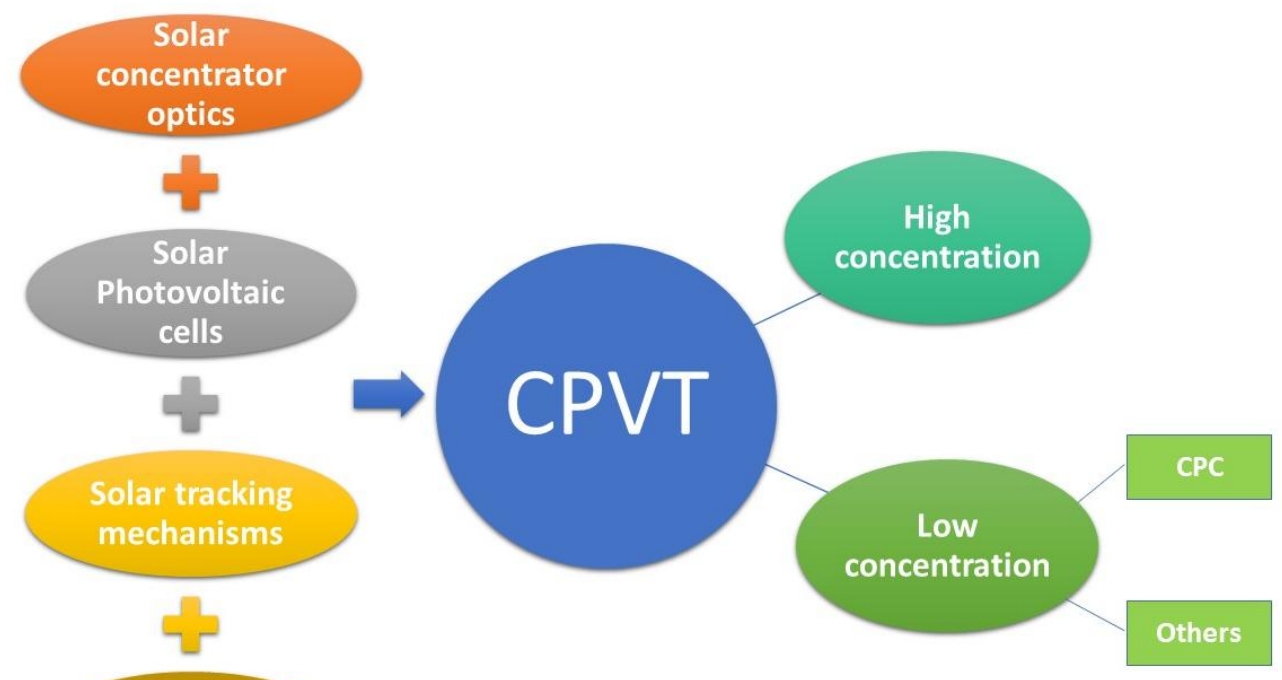

Solar Thermal

Collectors

Fig. 11. Hierarchy of CPVT system

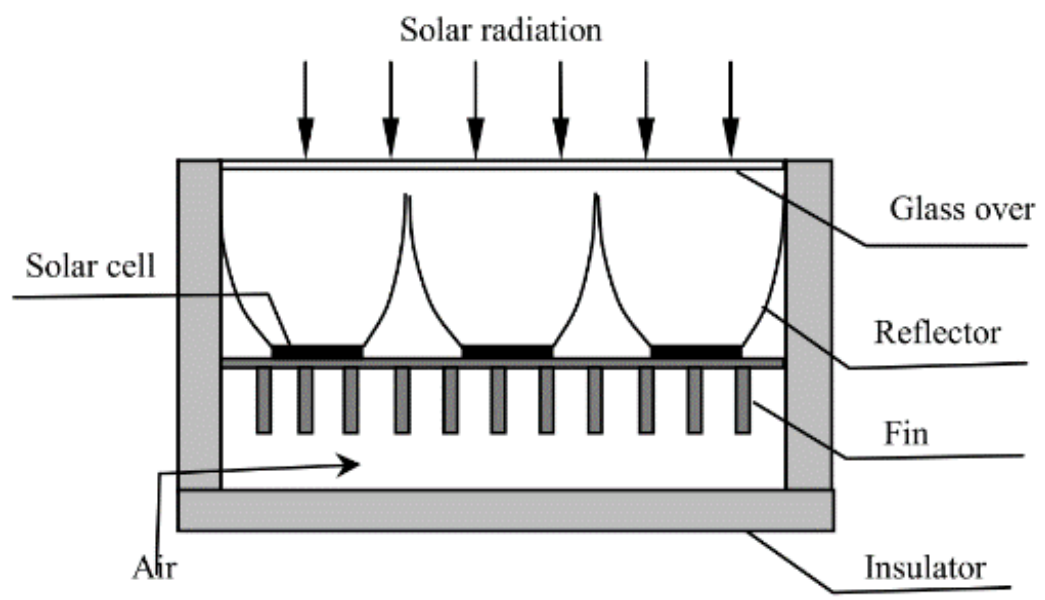

Fig. 12. Cross section view of the hybrid 2D CPC PV/T system [65] 


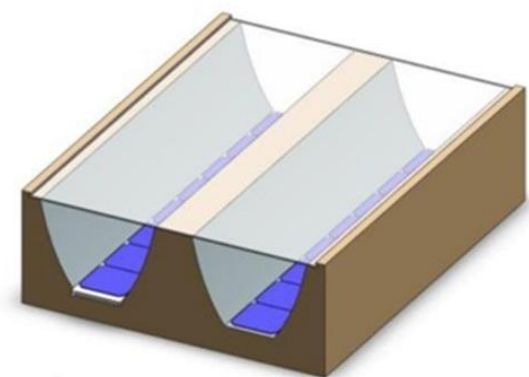

a)

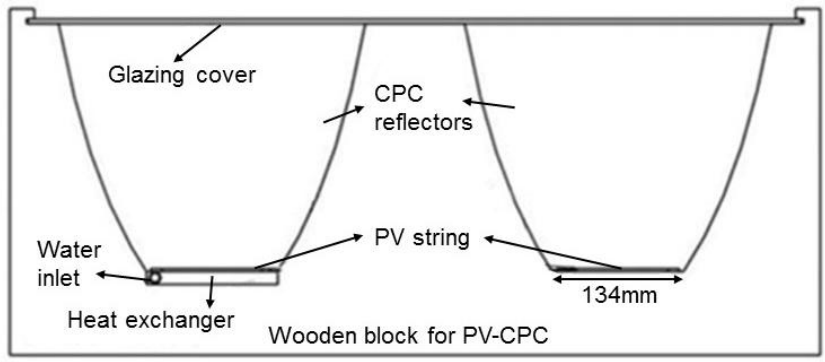

b)

Fig. 13. Schematic diagram of 2D trough CPC a) 3D model of glazed PV-CPC system $b$ ) cross section of glazed PV-CPC system with/without cooling pipes [66]

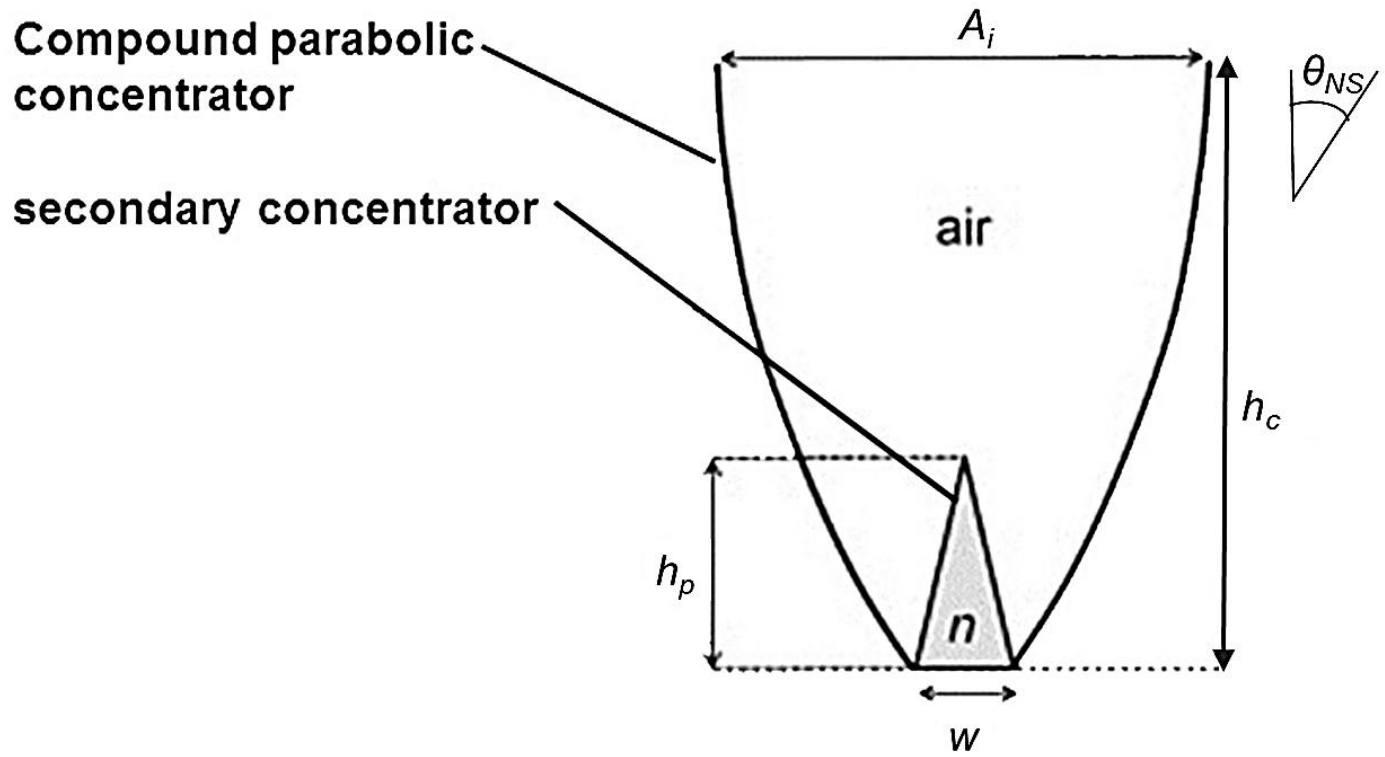

Fig. 14. Section view of CPC coupled with prism as secondary concentrator [84] 


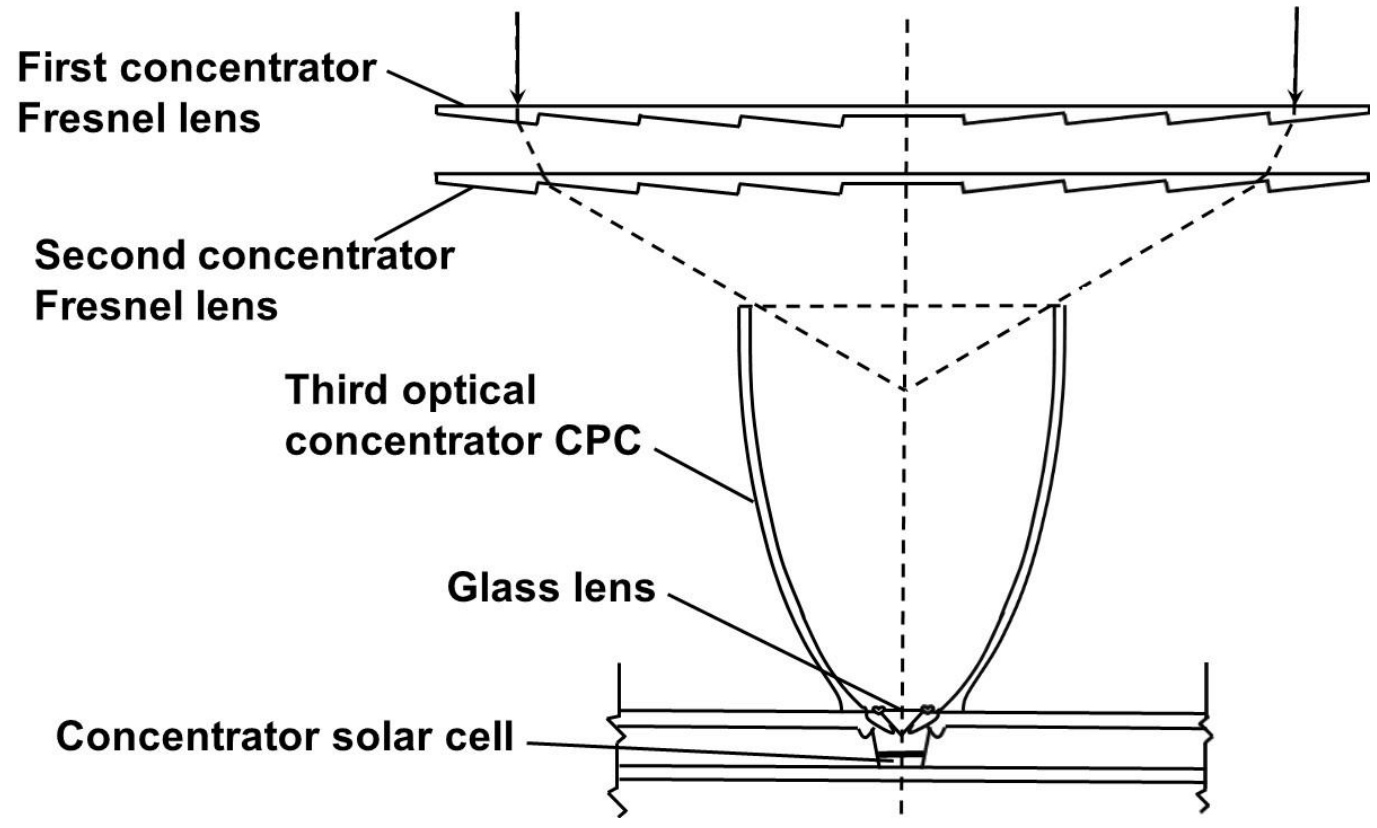

Fig. 15. Cross section of a high concentration system [87]

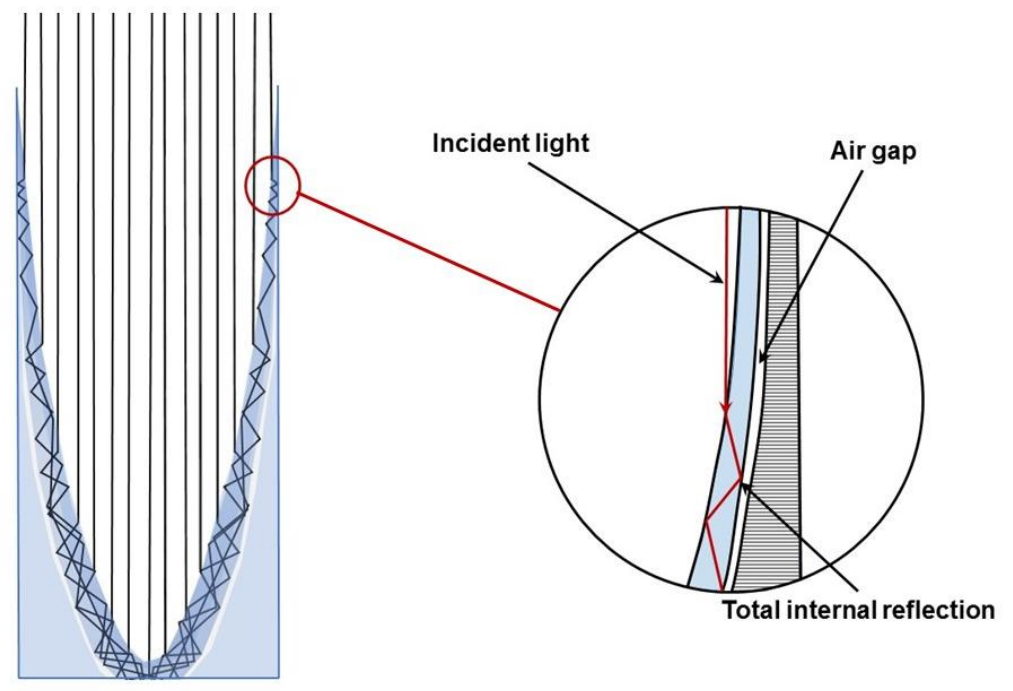

Fig. 16. Schematic diagram of lens-walled CPC with air gap [62] 


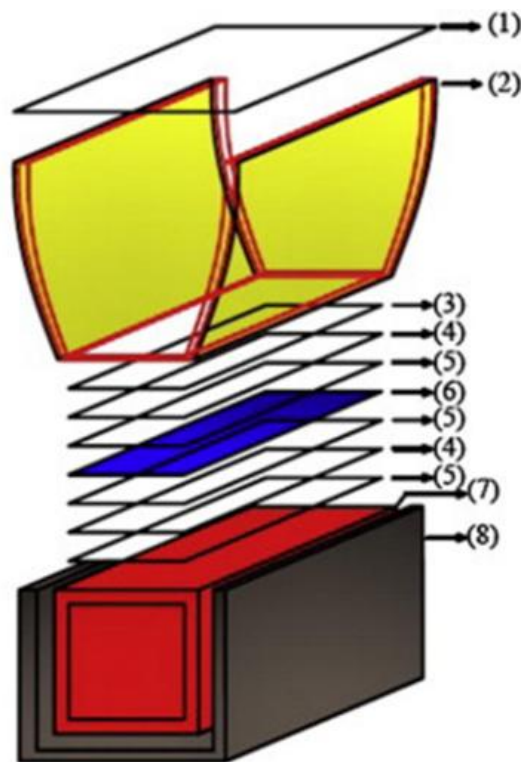

Fig. 17. Schematic diagram of lens-walled CPC with air gap integrating with PV/T system (1) Front glazing (2) Lens-walled CPC with air gap (3) UV Glue (4) TPT (tedlar-polyester-tedlar) (5) EVA (ethylene-vinylacetate) layers (6) PV cell (7) Copper pipe (8) Thermal insulation [63]

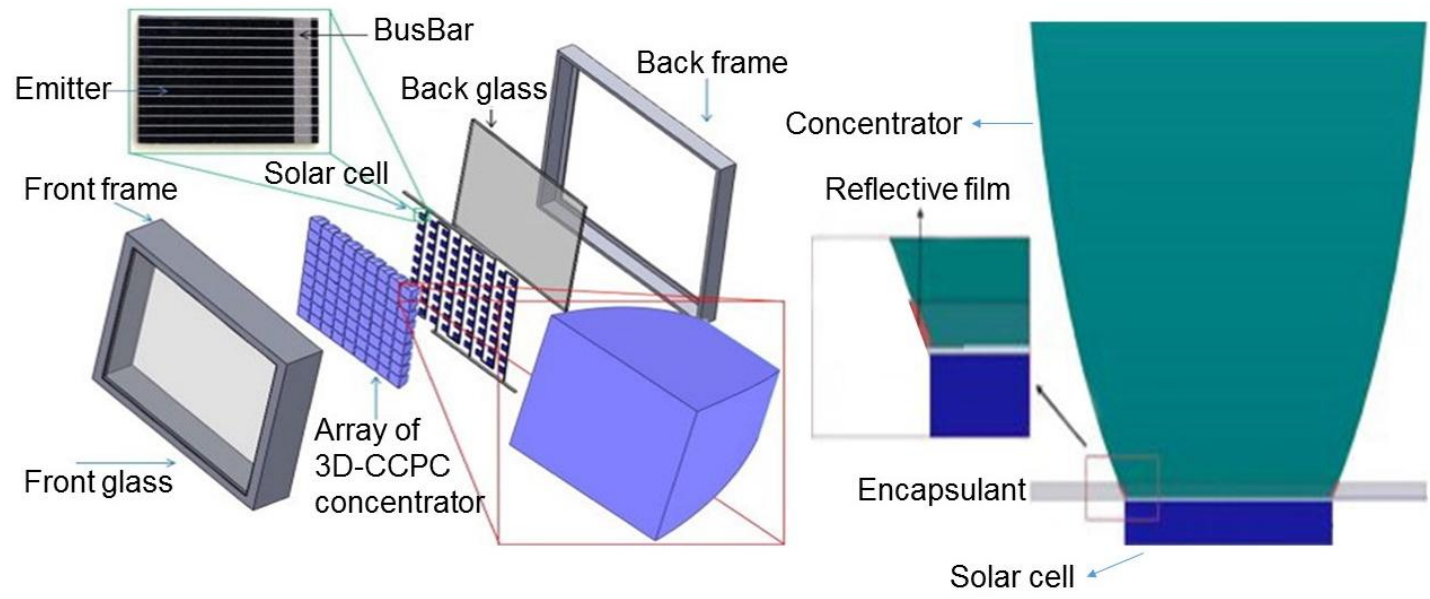

Fig. 18. Reflective film and encapsulant on CPV [76] 


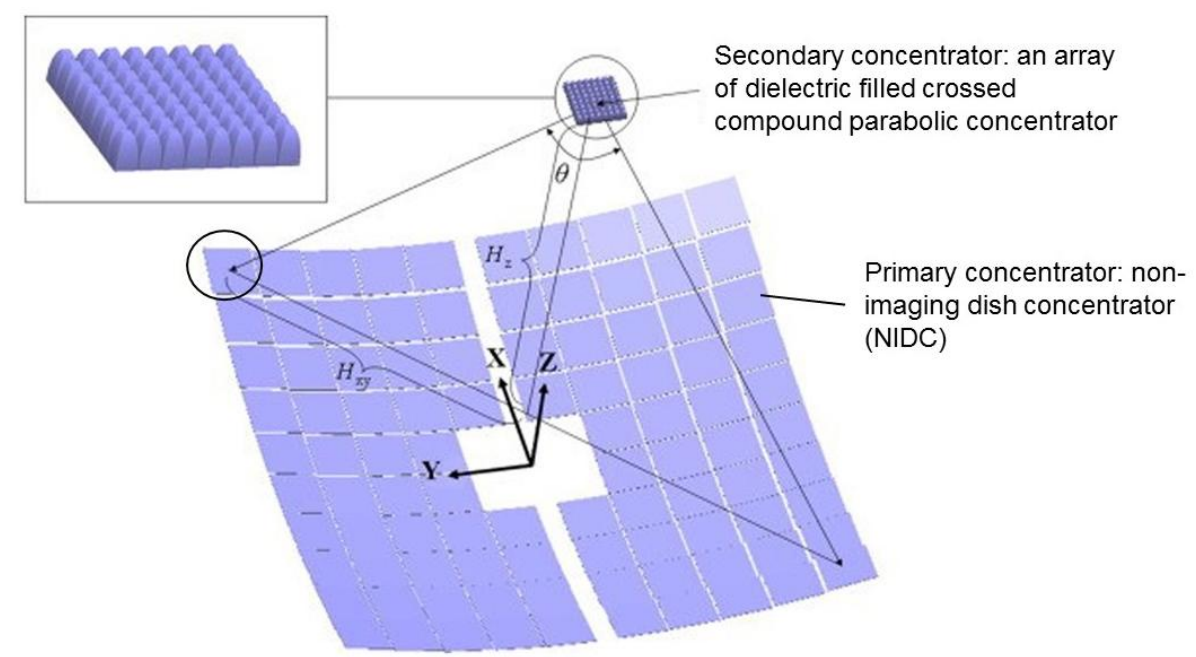

Fig. 19. Schematic diagram of CCPC integrating with non-imaging dish concentrator (NIDC) [95]

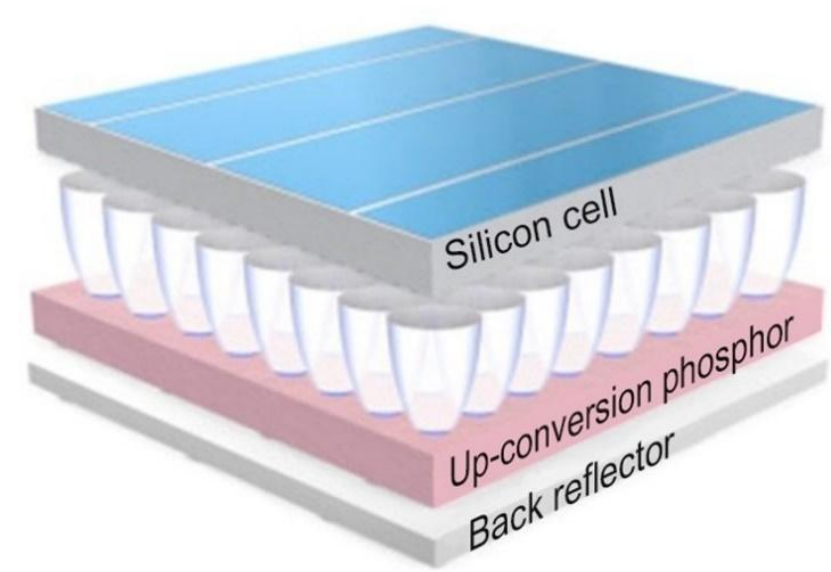

a)

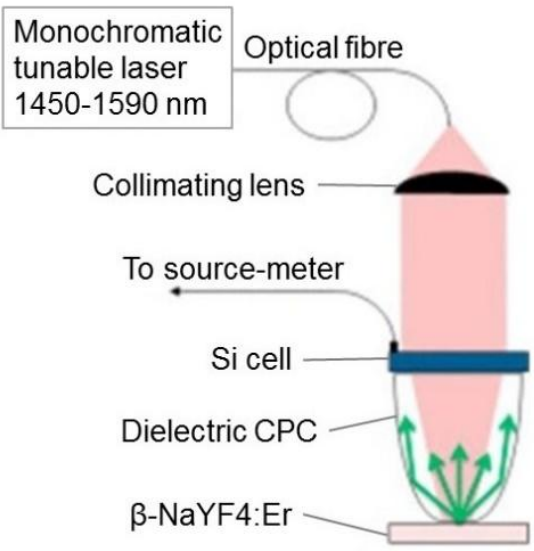

b)

Fig. 20. dCPC integrating with UC-SC, a) UC-SC with a regular two-dimension array of integrated dCPC; b) Schematic and optical setup [73] 


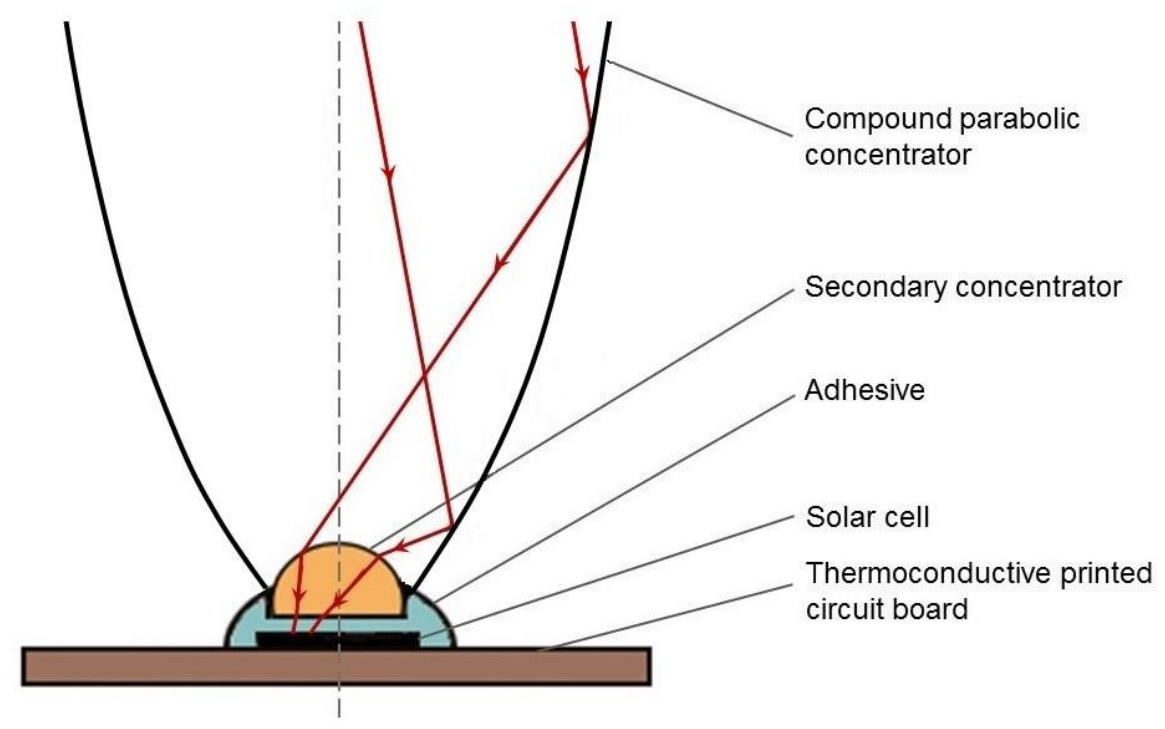

Fig. 21. Section view of CPC coupled with convex lens as secondary concentrator [97]

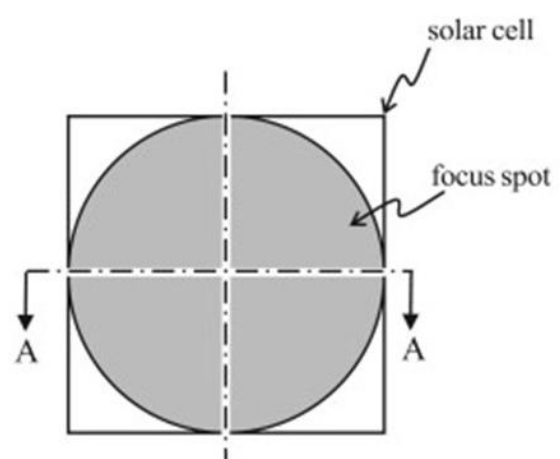

a)

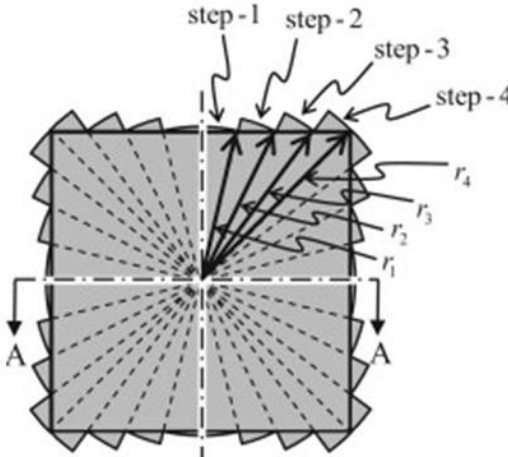

$\left.b_{1}\right)$

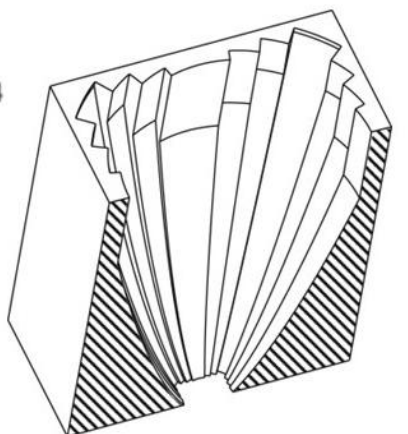

$\left.b_{2}\right)$

Fig. 22. Schematic diagram of VFP, a) Circular focus spot on solar cell; $b_{1}$ ) Square focus spot on solar cell; $b_{2}$ ) Cross section of VFP with square focus spot [98] 

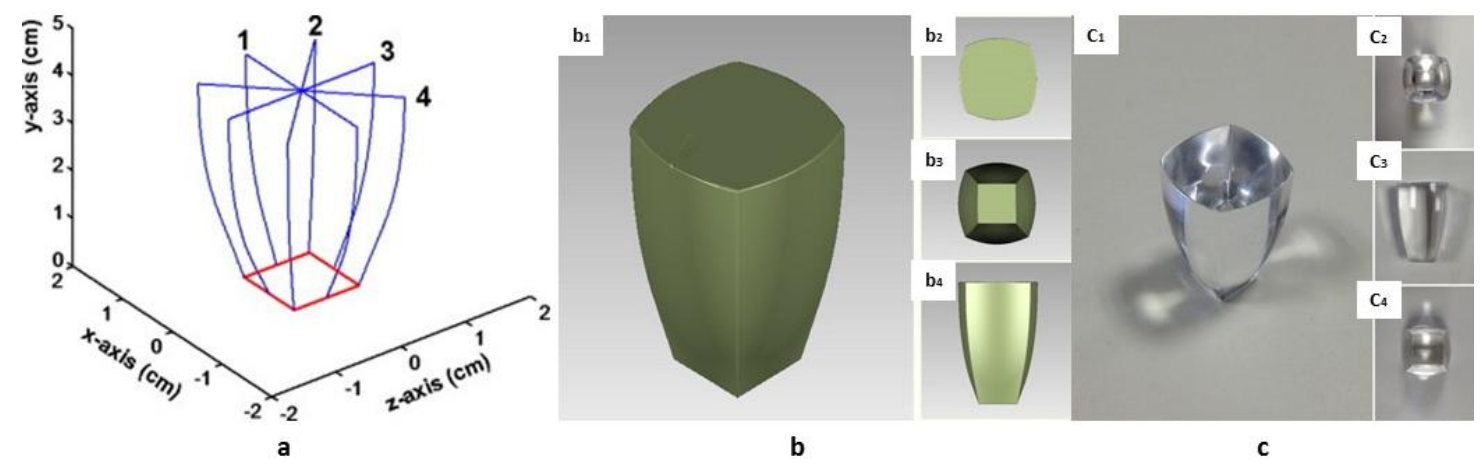

Fig. 23. Structure of RACPC, a) schematic diagram of producing RACPC by angular rotating 2D cross section; b) 3D model of RACPC; c) prototype of RACPC $[99,100]$

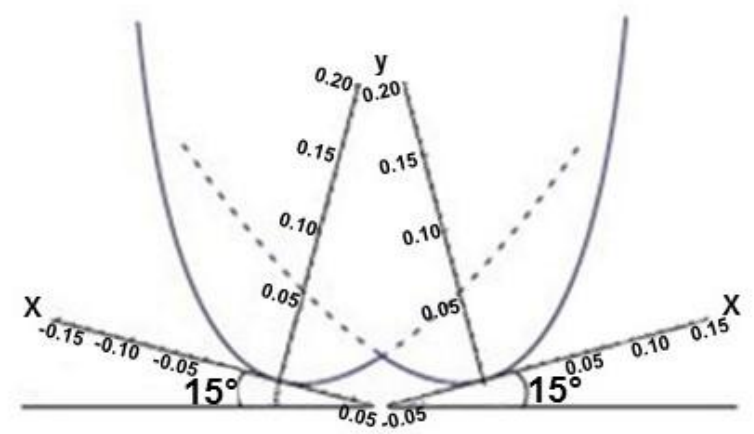

a1)

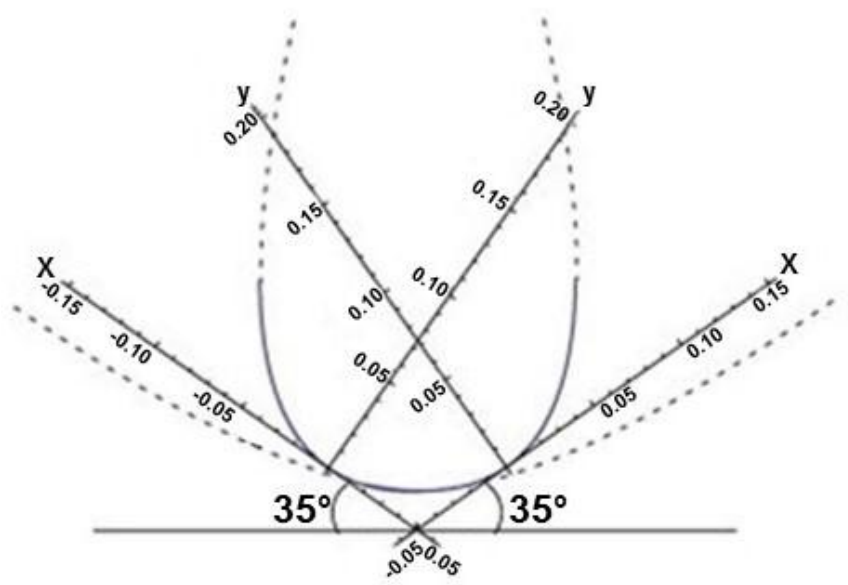

b1)

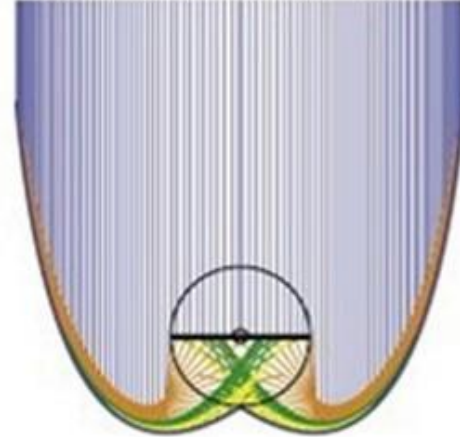

a2)

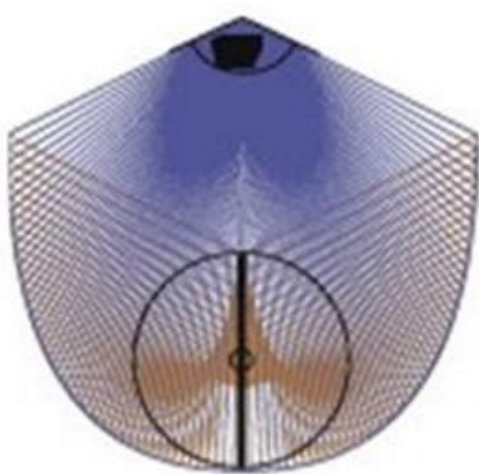

$\left.b_{2}\right)$

Fig. 24. Diagram of DPT and FBT, $a_{1}$ ) DPT is formed by rotating two parabola inwards by $15^{\circ} ; a_{2}$ ) DPT with horizontal disposition of flat plate absorber; $b_{1}$ ) FBT is formed by rotating the two parabola inwards until the base is flat; $b_{2}$ ) FBT with vertical disposition of flat plate absorber [105] 

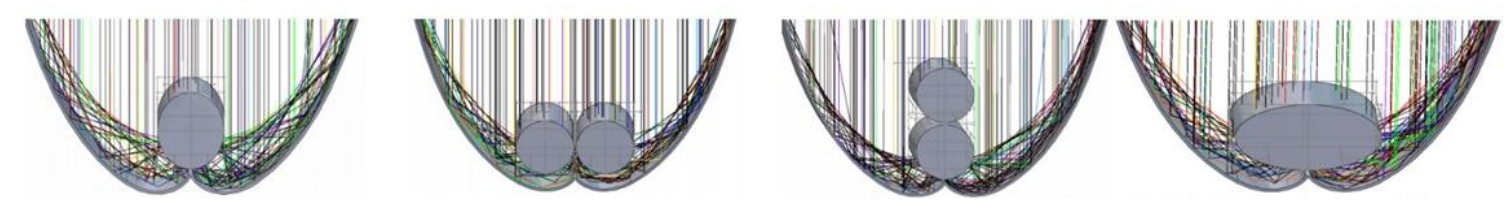

Fig. 25. Four CPC solar thermal collectors with different absorber [107]
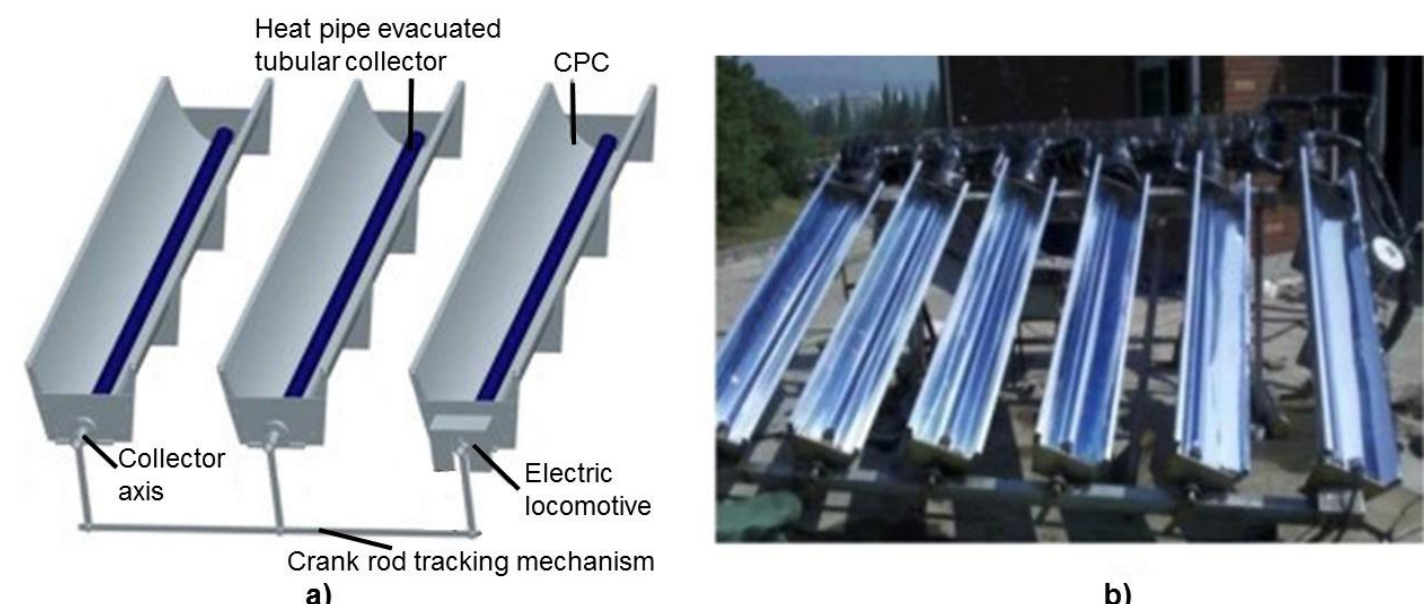

b)

Fig. 26. TCPC solar collector, a) The schematic view of TCPC collectors; b) photo of TCPC collectors

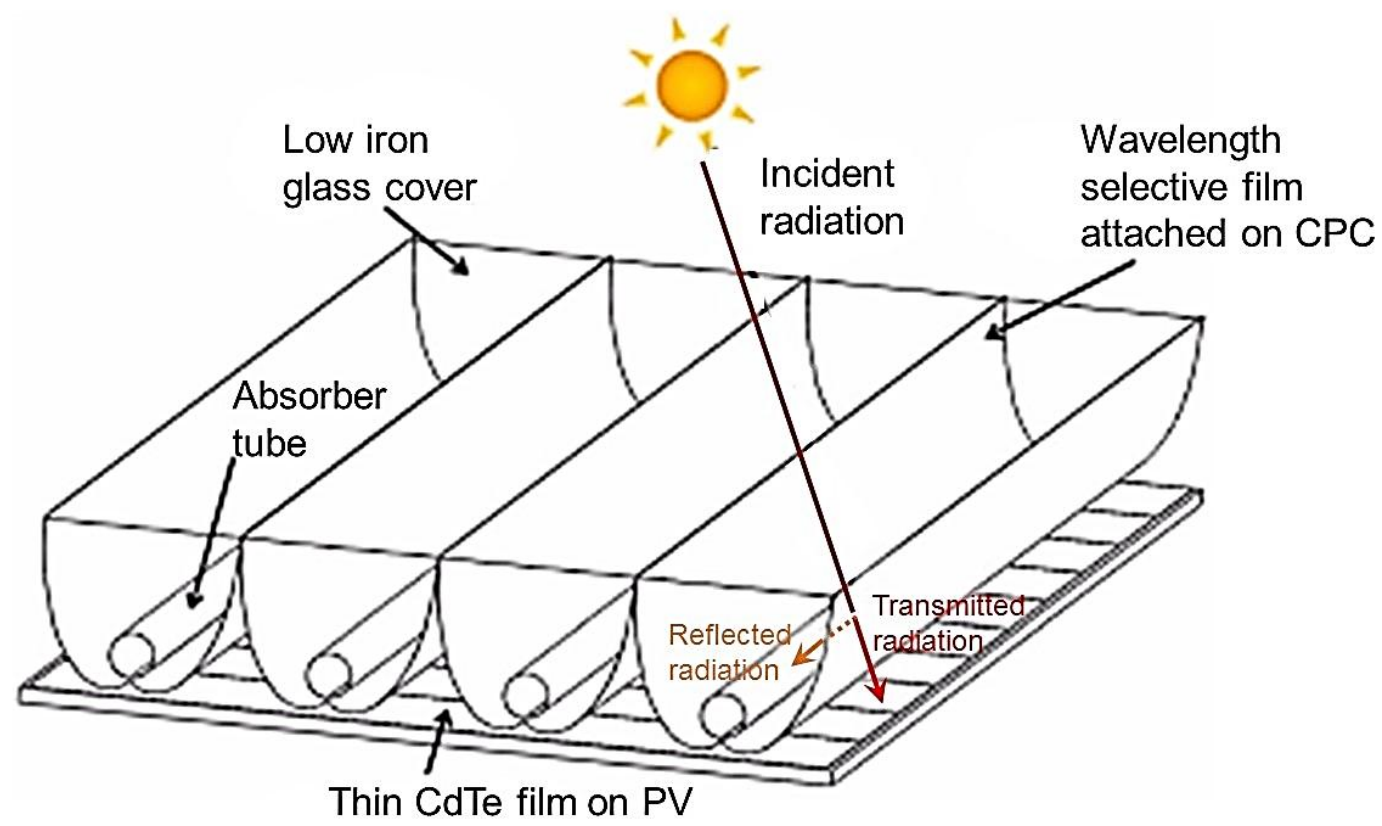

Fig. 27. Design concept for the hybrid CPC-PV/T system with wavelength selective film [112] 


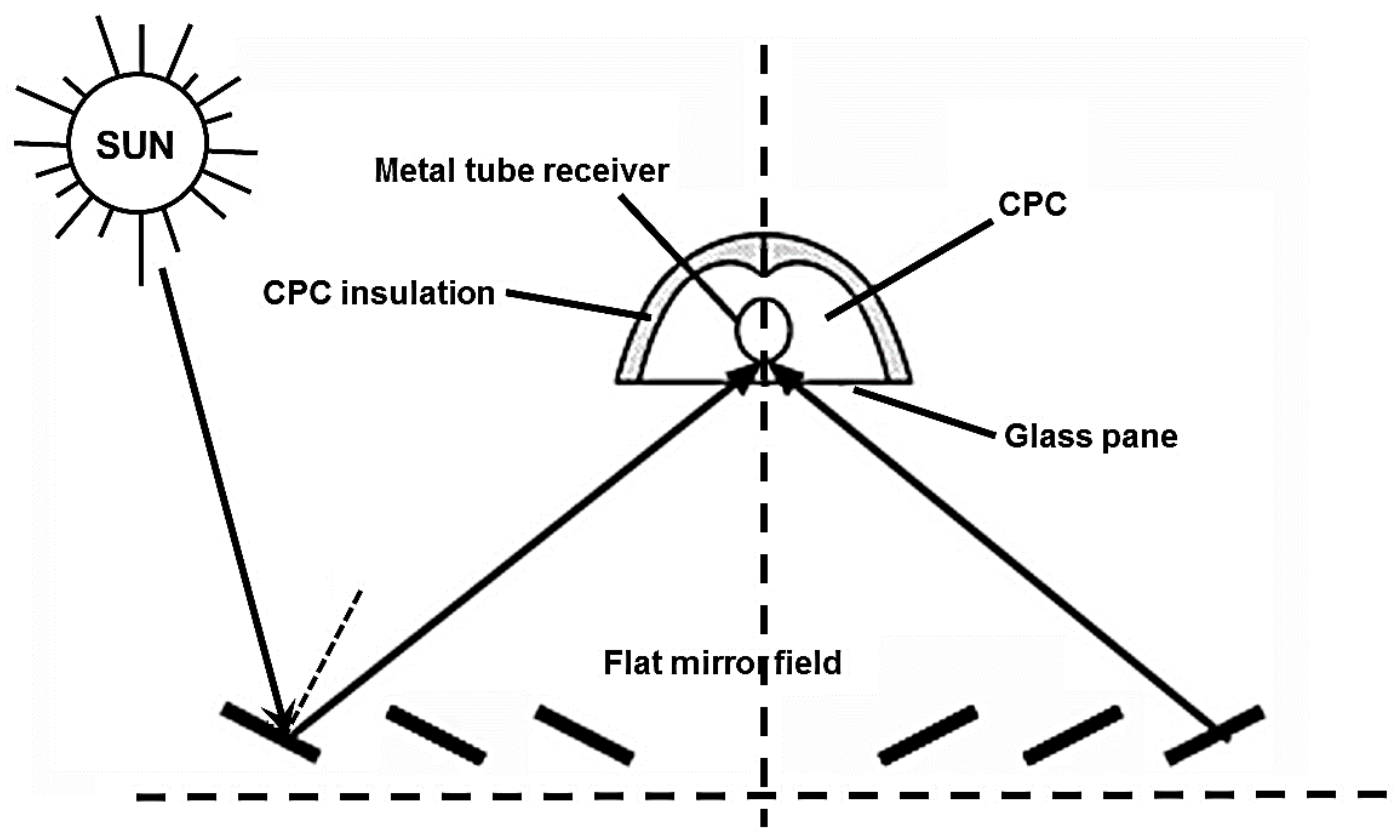

Fig. 28. Section view of concentration system consisting of CPC absorber and Fresnel reflector [113]

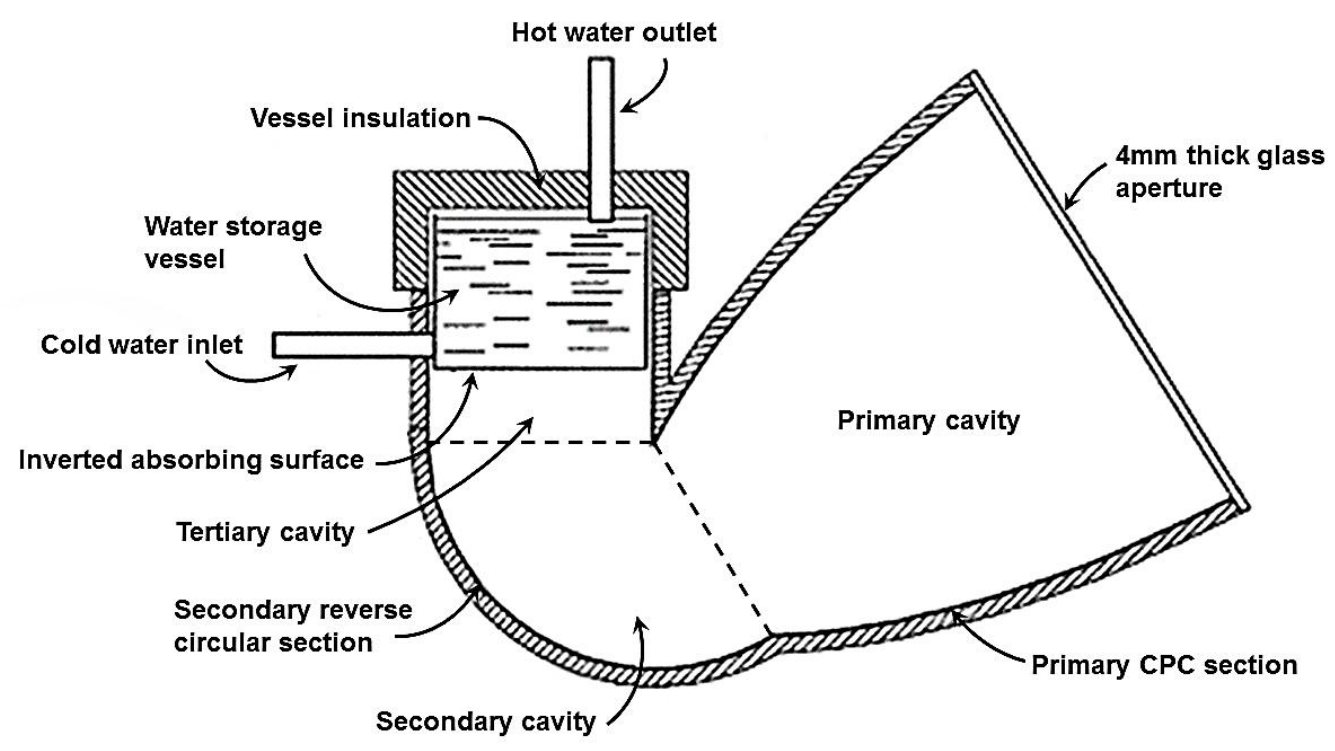

Fig. 29. Section view of inverted absorber ICSSWH [117] 


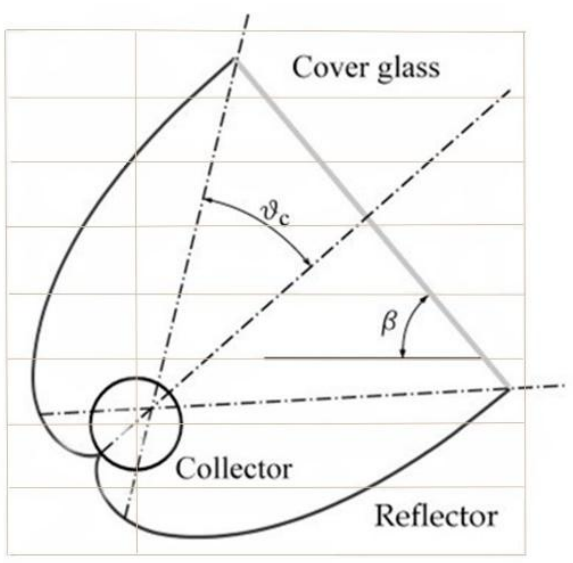

a)

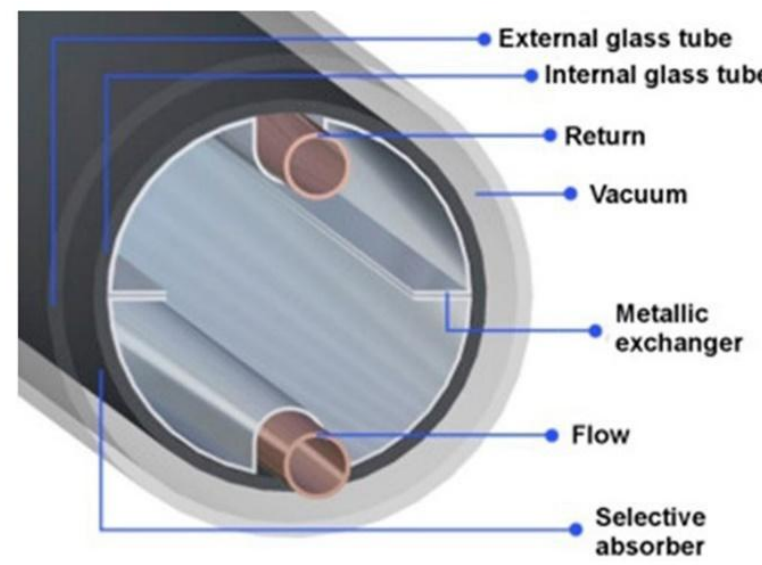

b)

Fig. 30. a) Schematic of CPC collector; b) Representation of an evacuated tube collector with Upipe [118]

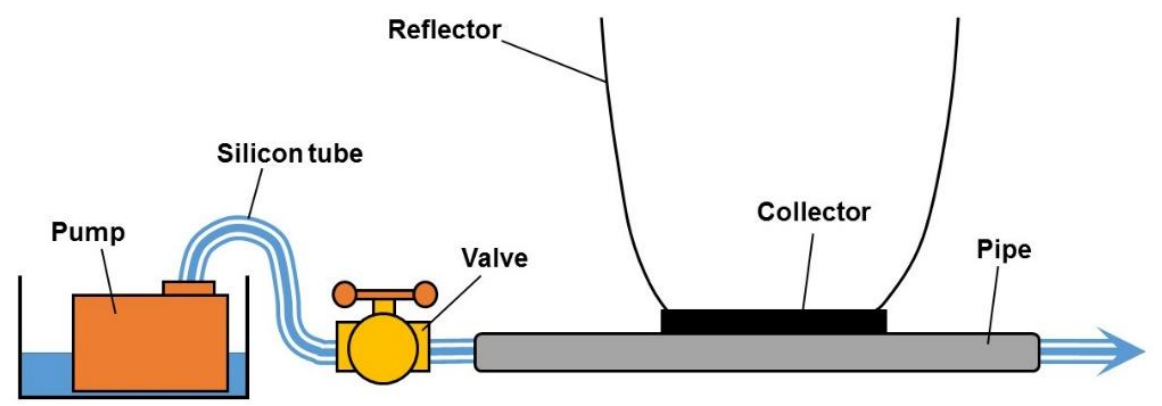

Fig. 31. Schematic diagram of water steam generation and distillation system with CPC [122]

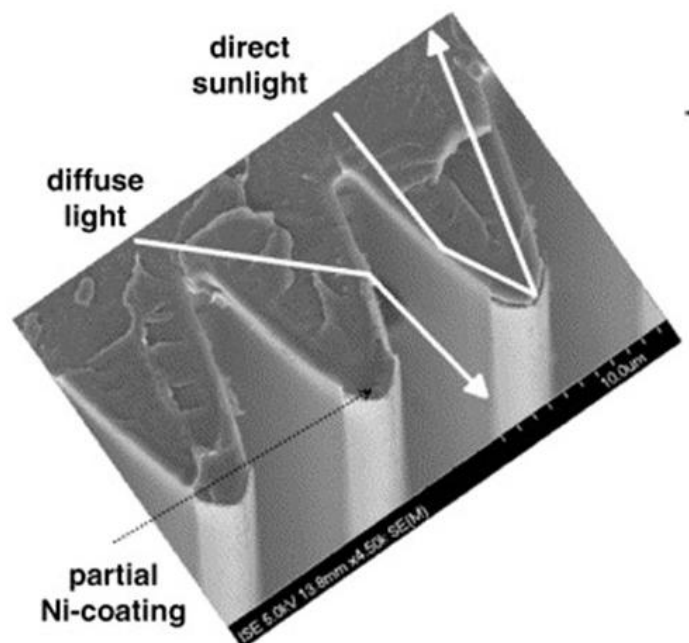

a)

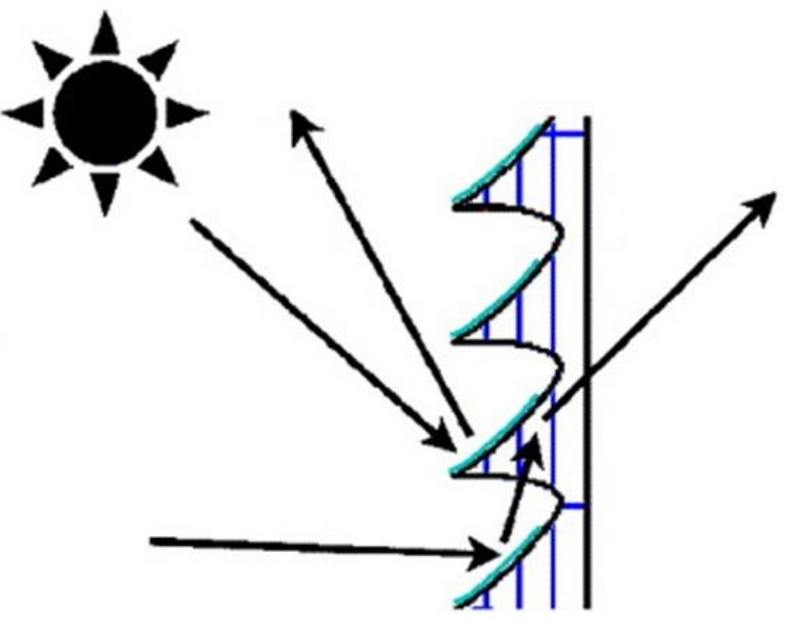

b)

Fig. 32. Two types of smart windows with 2D CPC array, a) Replication of CPC array generated by interference lithography in PMMA, with reflective coatings on base; b) CPC array with reflective coatings on side wall [70] 


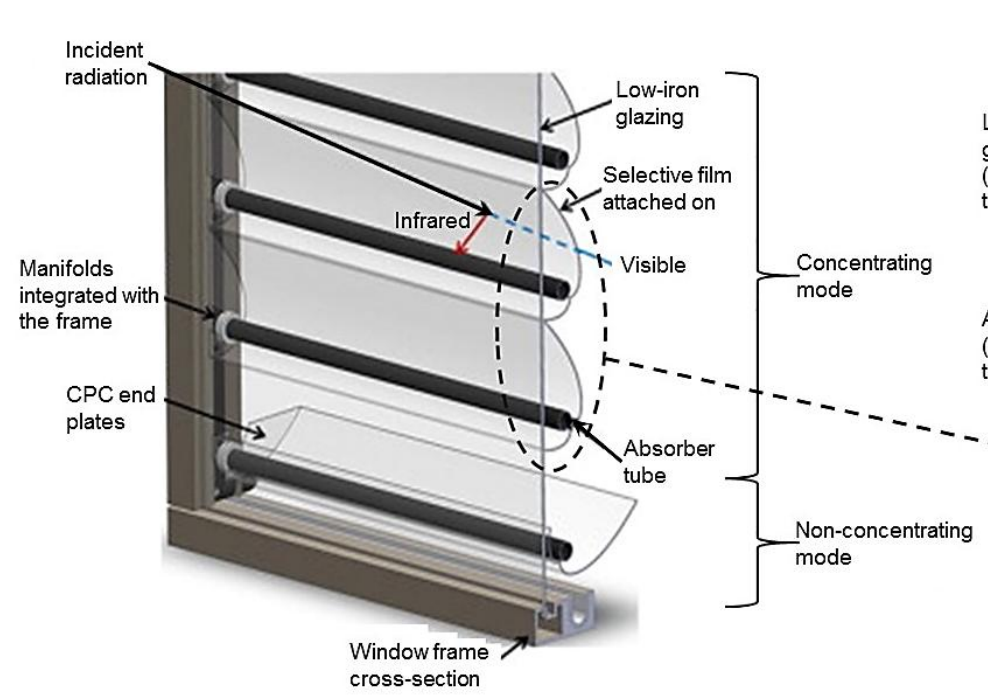

a)

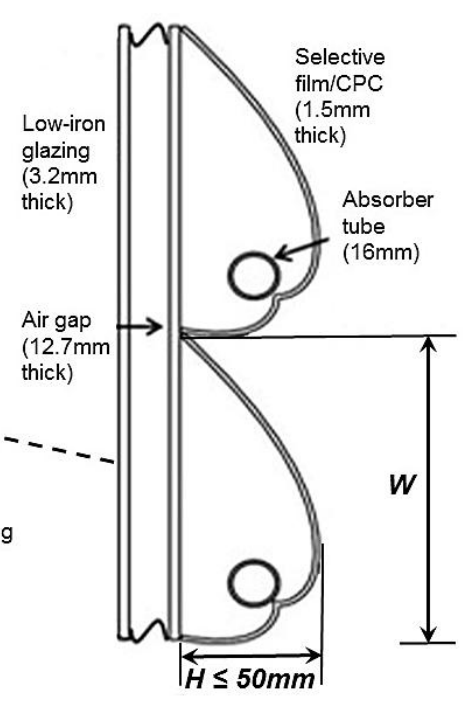

b)

Fig. 33. Schematic diagram of hybrid solar window, a) Design concept for hybrid solar window; b)

Typical cross-section view of hybrid solar window and dimensions [127]

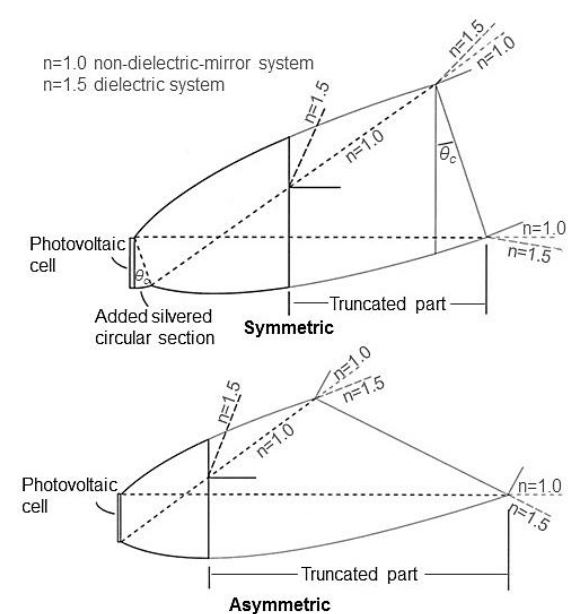

a)

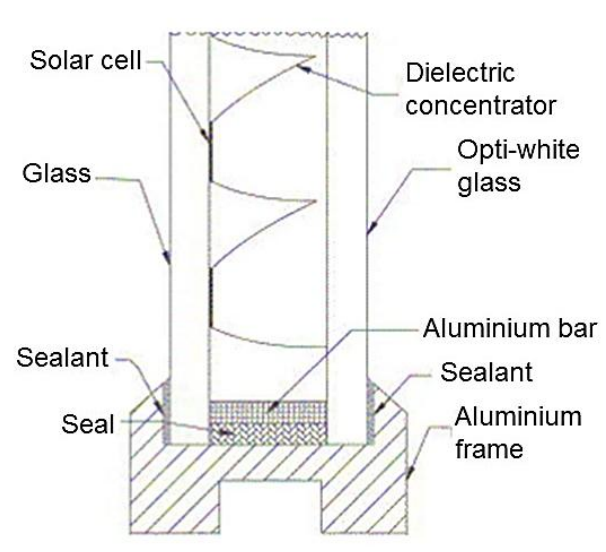

b)

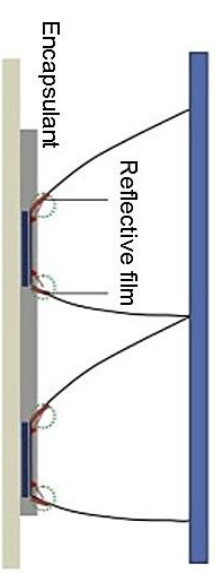

c)

Fig. 34. Schematic diagram of PRIDE systems, a) First generation with symmetric and asymmetric CPCs; b) Second generation; c) Third generation with reflective film on edge [67, 69, 72, 128-130]

Type 1

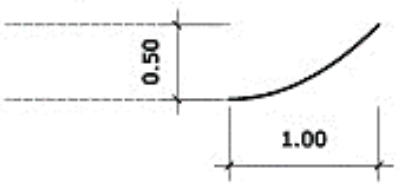

Type 2

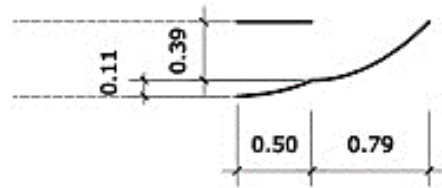

Type 3

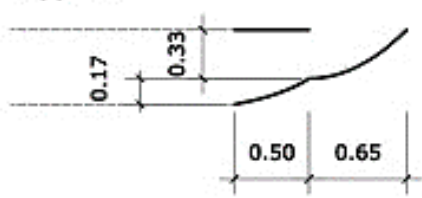

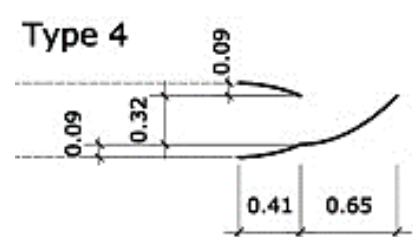

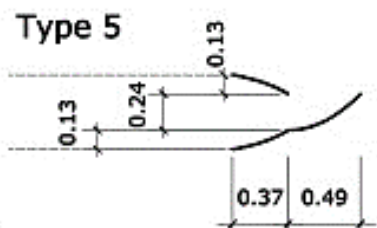

Type 6

Type 7
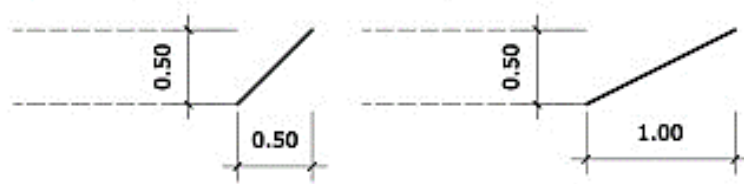

Fig. 35. Section of 5 anidolic collector systems (type 1-5) and two test collectors (type 6 and 7); abutting funnels are outlined in dashed lines (all sizes are in meter) [132] 


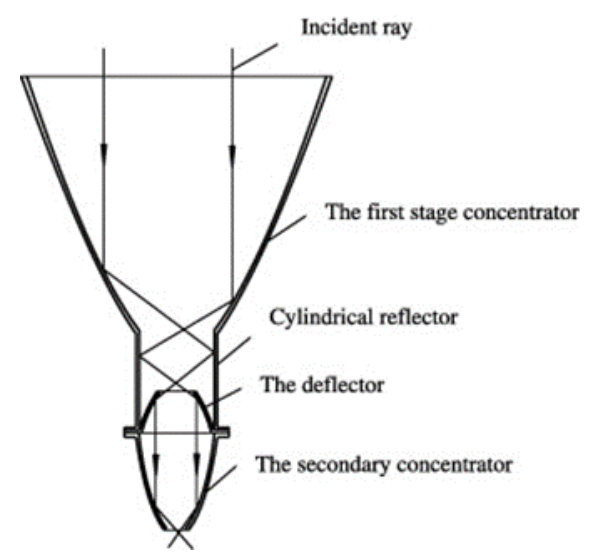

Fig. 36. Structure and optical path of the novel sunlight concentrator unit [133]

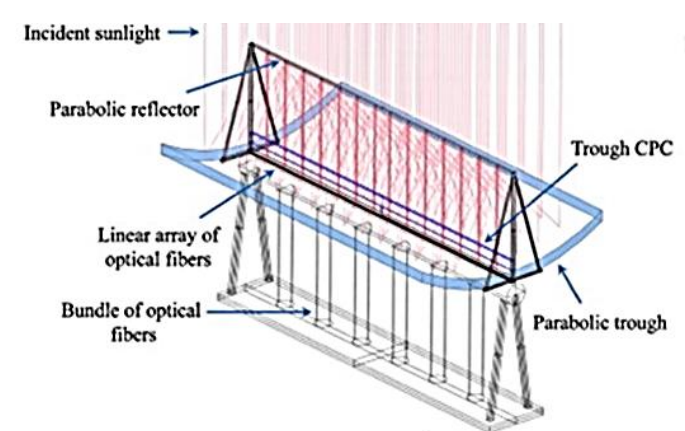

a)

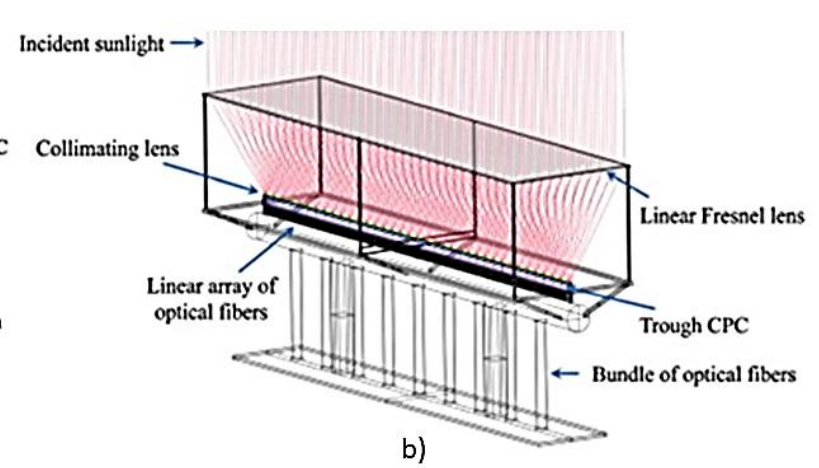

b)

Fig. 37. Conceptual schematic diagram of the daylighting systems, a) Parabolic trough type; b) Linear Fresnel lens type [134]

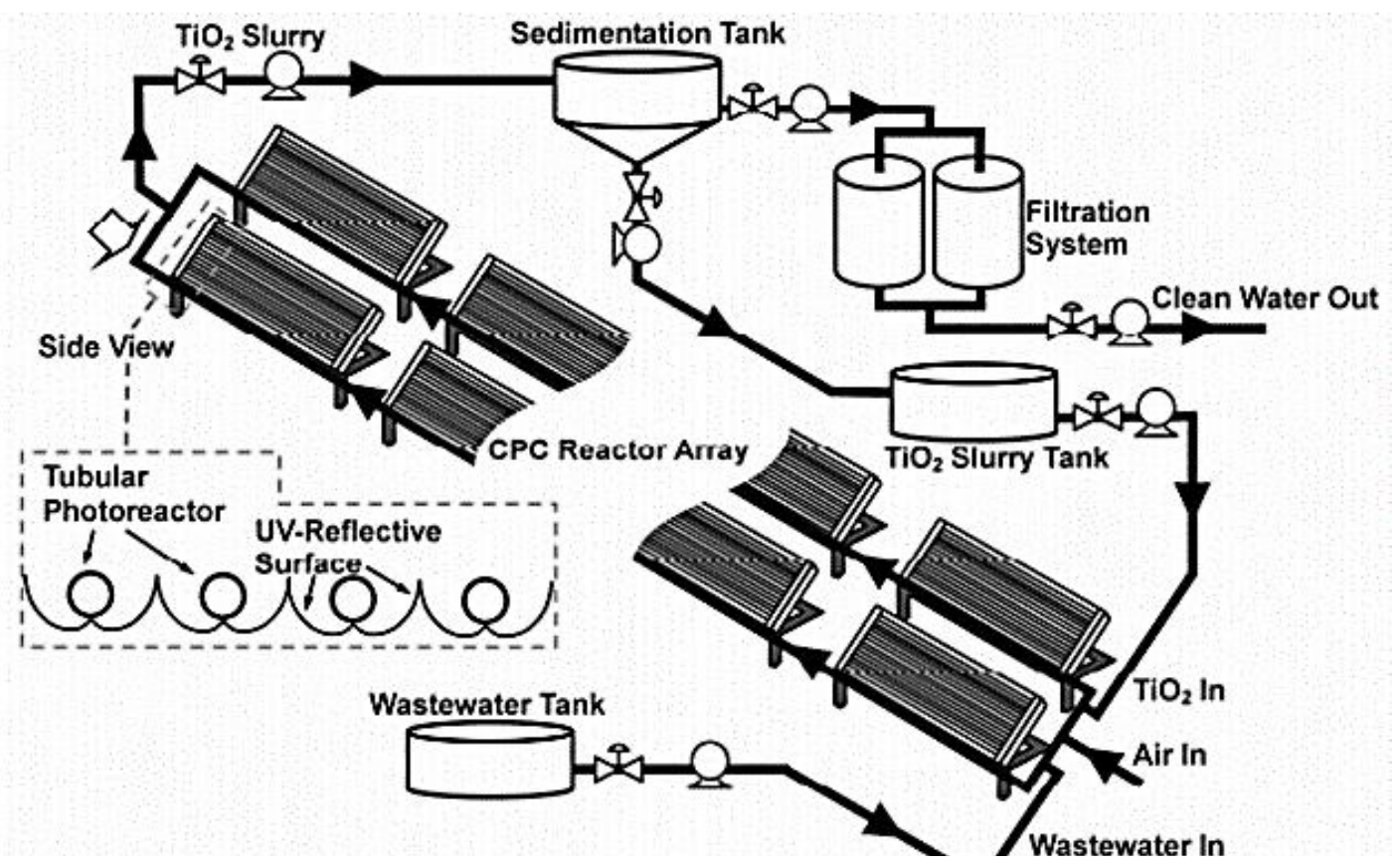

Fig. 38. Schematic diagram of a photocatalytic water purification system with CPC reactor [135] 


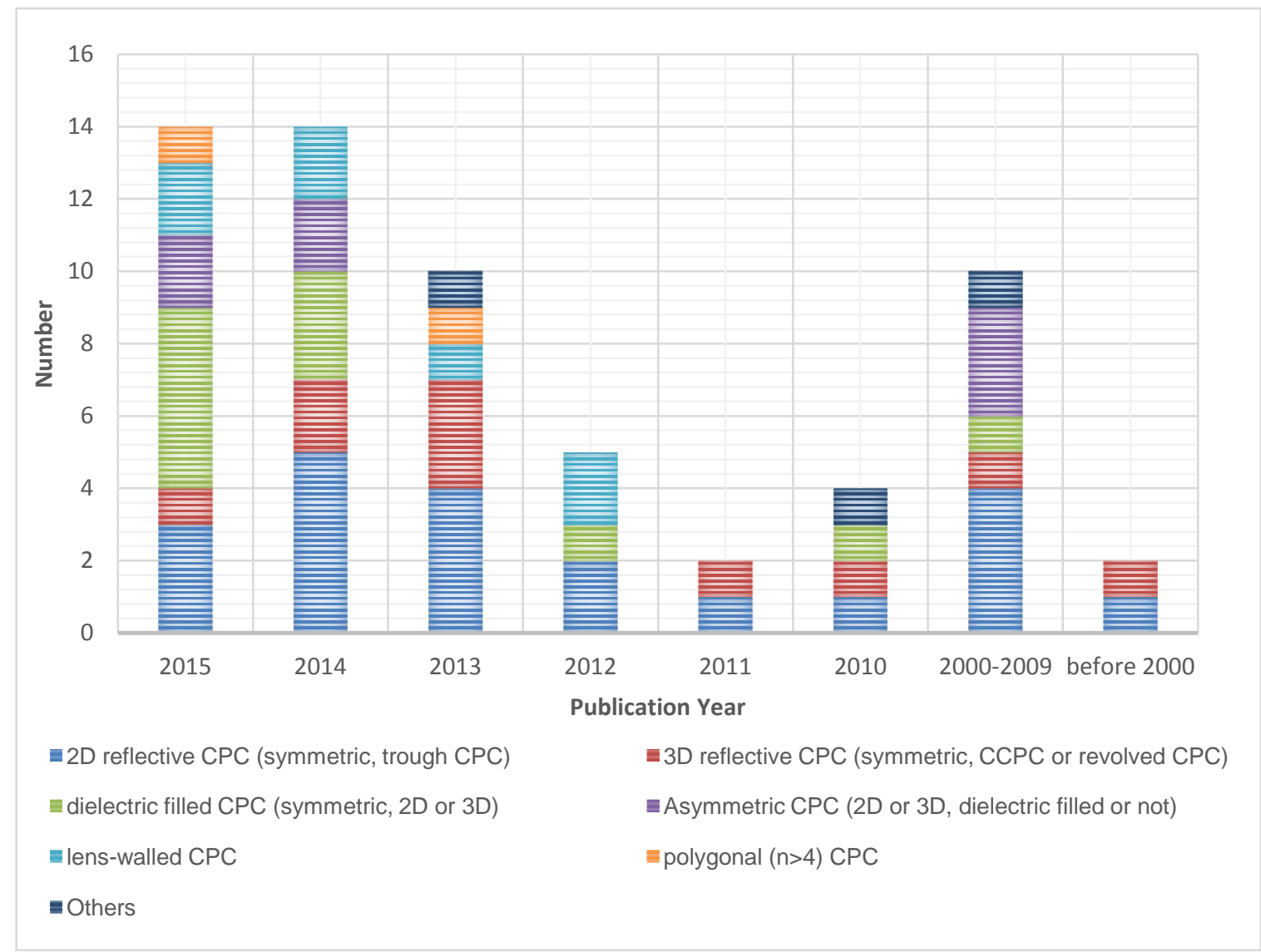

Figure 39. CPC studies according to publication year and CPC type

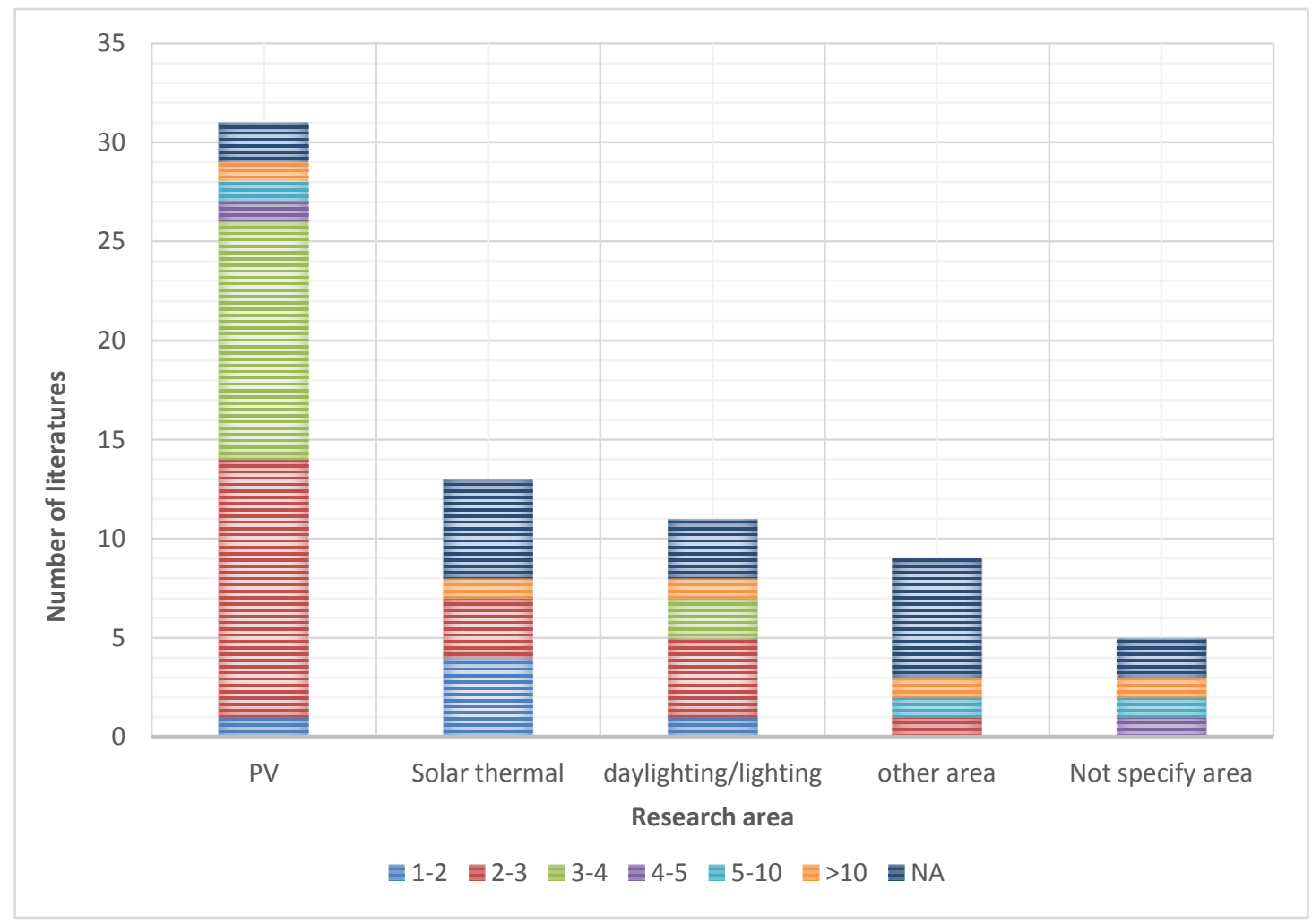

Figure 40. CPC studies according to application area and concentration ratio 


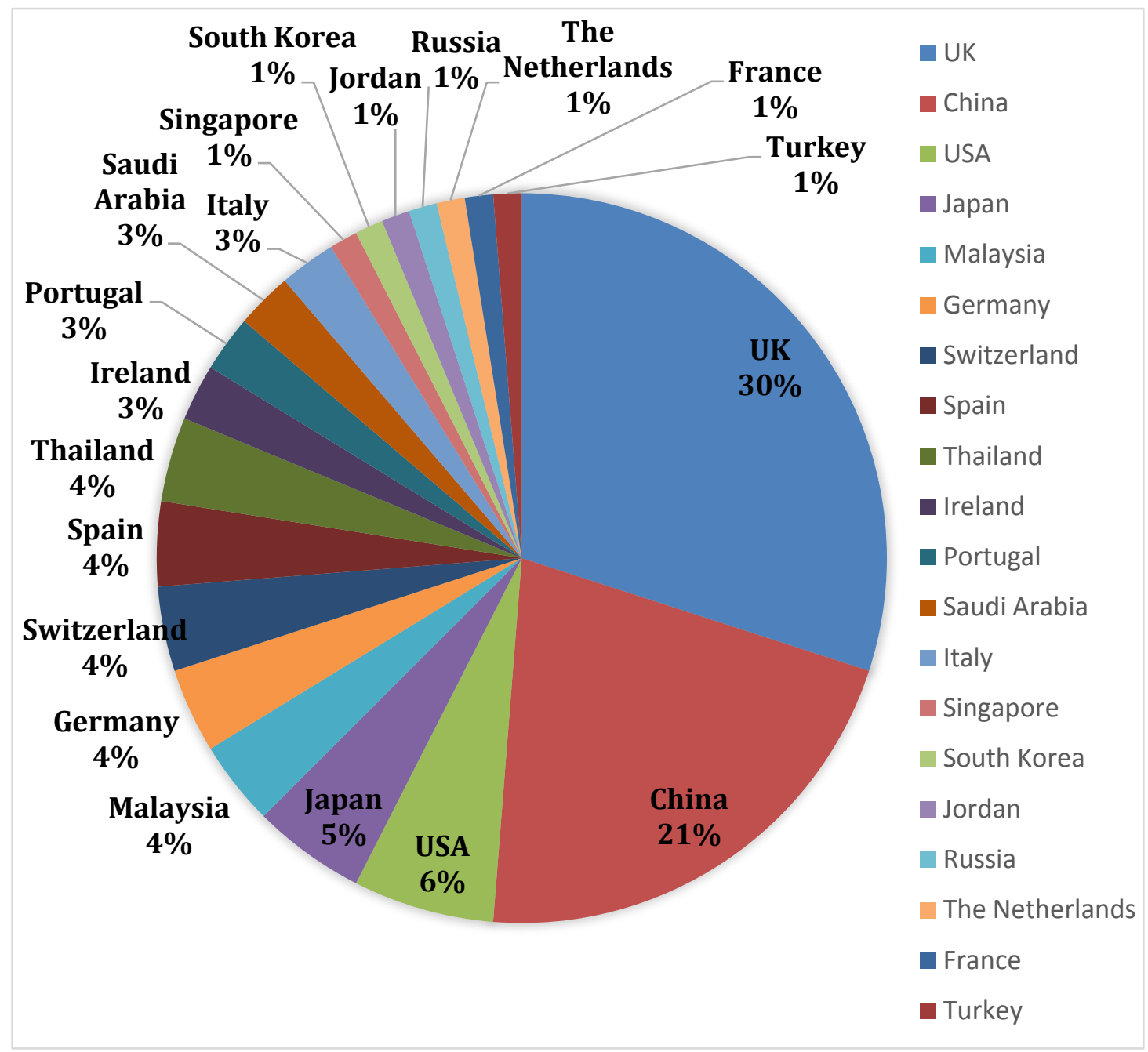

Figure 41. CPC studies according to countries of research institutes 


\title{
A review on the recent research progress in the compound parabolic concentrator (CPC) for solar energy applications
}

\author{
List of Tables
}

Table 1. Summary of the software used in CPC simulation

\begin{tabular}{|c|c|c|c|}
\hline Software name & Key features & Special features for CPC simulation & $\begin{array}{l}\text { Operating } \\
\text { platform }\end{array}$ \\
\hline MATLAB & $\begin{array}{l}\text {-High-level language and interactive environment } \\
\text {-For numerical computation, visualization and application development }\end{array}$ & $\begin{array}{l}\text {-New codes are required to be written for ray } \\
\text { tracing simulation } \\
\text {-Optimize CPC geometry }\end{array}$ & $\begin{array}{l}\text { Windows, } \\
\text { Mac, Linux }\end{array}$ \\
\hline Simulink & $\begin{array}{l}\text {-An additional package of MATLAB } \\
\text {-Block diagram environment for multidomain simulation and model based } \\
\text { design }\end{array}$ & $\begin{array}{l}\text {-Simulate electricity generation of CPV system } \\
\text {-Simulate solar thermal collection of CPC } \\
\text { system }\end{array}$ & $\begin{array}{l}\text { Windows, } \\
\text { Mac, Linux }\end{array}$ \\
\hline LightTools & $\begin{array}{l}\text {-3D optical engineering and design software } \\
\text {-Supports virtual prototyping, simulation, optimization and photorealistic } \\
\text { renderings of illumination application } \\
\text {-Provide point-and-shoot ray tracing and Monte Carlo simulations } \\
\text {-Incorporates with CAD, SOLIDWORKS and other COM-enabled applications, } \\
\text { like Microsoft Excel or MATLAB }\end{array}$ & $\begin{array}{l}\text {-Provides accurate predictions of colorimetric } \\
\text { performance }\end{array}$ & Windows \\
\hline
\end{tabular}




\begin{tabular}{|c|c|c|c|}
\hline ZEMAX & $\begin{array}{l}\text {-An optical and illumination design software } \\
\text {-Applied for both imaging and illumination system } \\
\text {-Provides standard sequential ray tracing through optical elements, non- } \\
\text { sequential ray tracing for analysis of stray light and physical optics beam } \\
\text { propagation }\end{array}$ & $\begin{array}{l}\text {-Its versatile features meet the requirements of } \\
\text { CPC analysis under either normal or special } \\
\text { conditions, such as simulate the optoelectronic } \\
\text { gain of RACPC, the performance of diode pump } \\
\text { with CPC, etc. }\end{array}$ & Windows \\
\hline APEX & $\begin{array}{l}\text {-An add-in of SOLIDWORKS for analyzing optical and illumination system } \\
\text {-The core of APEX is time-proven ray tracing engine in BRO's ASAP }\end{array}$ & $\begin{array}{l}\text {-Create, design and analyze in one program } \\
\text { environment } \\
\text { - Simulate optical and illumination system with } \\
\text { an easy-to-follow workflow }\end{array}$ & Windows \\
\hline TracePro & $\begin{array}{l}\text {-A commercial, fast and accurate optical engineering software program } \\
\text {-Incorporates with CAD products and the software using a Dynamic Data } \\
\text { Exchange client/server interface } \\
\text {-Has an add-in to SOLIDWORKS }\end{array}$ & $\begin{array}{l}\text { - Provides Monte Carlo simulations for CPCs } \\
\text { - Define custom properties or choose from } \\
\text { database of commercially-available materials } \\
\text { and coatings }\end{array}$ & Windows \\
\hline $\begin{array}{l}\text { COMSOL } \\
\text { Multiphysics }\end{array}$ & $\begin{array}{l}\text {-A finite element analysis, solver and simulation software package } \\
\text {-Model and simulate coupled or multiphysics phenomena simultaneously } \\
\text {-For cross disciplinary product development with a unified workflow }\end{array}$ & $\begin{array}{l}\text {-Incorporates with various software like CAD } \\
\text { and SOLIDWORKS } \\
\text {-Simulate the electricity output of CPV system }\end{array}$ & $\begin{array}{l}\text { Windows, } \\
\text { Mac, Linux }\end{array}$ \\
\hline OptisWorks & $\begin{array}{l}\text {-The only software to provide a complete solution for optical simulation in } \\
\text { CAD/CAM } \\
\text {-Simulation is based on physical model and SPEOS technology } \\
\text {-Simulations are for light and human vision within a Virtual Reality } \\
\text { Environment }\end{array}$ & $\begin{array}{l}\text {-Provides complete optical simulation solution } \\
\text { in CAD/CAM } \\
\text {-Provides Monte Carlo simulations for CPCs }\end{array}$ & Windows \\
\hline $\begin{array}{l}\text { Radiance and } \\
\text { The RADIANCE } \\
\text { Photon map } \\
\text { (Pmap) } \\
\text { Extension }\end{array}$ & $\begin{array}{l}\text {-A versatile lighting simulation system } \\
\text {-A physically based renders with available source code for UNIX computers } \\
\text {-Use light-backwards ray-tracing method } \\
\text {-Photon map is based on a light particle transport simulation by a Monte } \\
\text { Carlo sampling method }\end{array}$ & $\begin{array}{l}\text {-Can obtain not only accurate ray-tracing } \\
\text { results, but photon map for analyzing the light } \\
\text { source distributions in annual and climate- } \\
\text { based daylight simulations }\end{array}$ & $\begin{array}{l}\text { Windows, } \\
\text { Mac, Linux }\end{array}$ \\
\hline
\end{tabular}




\begin{tabular}{|c|c|c|c|}
\hline Photopia & $\begin{array}{l}\text {-An fast and accurate photometric analysis program } \\
\text {-For non-imaging optical designs } \\
\text {-The results are obtained based on probabilistic method } \\
\text {-The source model are based on the ISENA RP-21 daylight equations }\end{array}$ & $\begin{array}{l}\text {-Provides a large selection of sun and sky dome } \\
\text { models and numerous material data } \\
\text {-Incorporates with Auto CAD and also available } \\
\text { as an add-in for SOLIDWORKS }\end{array}$ & Windows \\
\hline ANSYS CFX, CFD & $\begin{array}{l}\text {-High-performance computational CFD tools } \\
\text {-Designed for complete virtual prototypes of complex products and systems } \\
\text {-Has revolutionized fluid dynamics by automating the solution }\end{array}$ & $\begin{array}{l}\text {-Incorporates with other CAD tools } \\
\text {-CFX can also be used to analyze the optical } \\
\text { performance for CPC except thermal } \\
\text { performance }\end{array}$ & $\begin{array}{l}\text { Windows, } \\
\text { Linux }\end{array}$ \\
\hline $\begin{array}{l}\text { Engineering } \\
\text { Equation Solver } \\
\text { (EES) }\end{array}$ & $\begin{array}{l}\text {-A high accurate software to numerically solve thousands of coupled non- } \\
\text { linear algebraic and differential equations } \\
\text {-Provide a high accuracy thermal dynamic and transport property database } \\
\text {-Accepts user-written functions, procedures, modules and tabular data }\end{array}$ & $\begin{array}{l}\text {-Can deal with the optical, thermal and } \\
\text { electrical performance for CPC and CPV } \\
\text { systems } \\
\text {-Specific models are required for typical } \\
\text { simulations }\end{array}$ & $\begin{array}{l}\text { Windows, } \\
\text { Linux } \\
\text { using } \\
\text { Wine }\end{array}$ \\
\hline $\begin{array}{l}\text { Advanced } \\
\text { modelling } \\
\text { Environment for } \\
\text { performing } \\
\text { Simulation of } \\
\text { engineering } \\
\text { system } \\
\text { (AMESim) }\end{array}$ & $\begin{array}{l}\text {-A commercial simulation software for the modeling and analysis of multi- } \\
\text { domain systems. } \\
\text {-Models are described by nonlinear time-dependent analytical equations that } \\
\text { represent the behavior of systems. } \\
\text {-Doesn't require a full 3D geometry representation of system } \\
\text {-Allow users focus on design and engineering issues rather than spending } \\
\text { time in creating and validating models. }\end{array}$ & $\begin{array}{l}\text {-Simulate thermal performance of CPC } \\
\text { collectors. }\end{array}$ & $\begin{array}{l}\text { Windows, } \\
\text { UNIX, } \\
\text { Linux }\end{array}$ \\
\hline
\end{tabular}


Table 2. Comparison of CPC studies covered in manuscript (NA: Not available; the test prototype without additional comments are indoor experiment)

\begin{tabular}{|c|c|c|c|c|c|c|c|c|c|c|}
\hline $\begin{array}{l}\text { Categori } \\
\text { es }\end{array}$ & $\begin{array}{l}\text { Refer } \\
\text { ence }\end{array}$ & Country & $\begin{array}{l}\text { Publicati } \\
\text { on year }\end{array}$ & CPC type & $\begin{array}{l}\text { Extent of } \\
\text { study }\end{array}$ & $\begin{array}{l}\text { Research methodology } \\
\text { /Software }\end{array}$ & $\begin{array}{l}\text { Application } \\
\text { area }\end{array}$ & Tracking & $\begin{array}{l}\text { concentr } \\
\text { ation } \\
\text { ratio }\end{array}$ & $\begin{array}{l}\text { Half } \\
\text { acceptanc } \\
\text { e angle }\end{array}$ \\
\hline \multirow{5}{*}{$\begin{array}{l}\text { Design } \\
\text { consider } \\
\text { ation }\end{array}$} & [51] & $\begin{array}{l}\text { The } \\
\text { Netherlan } \\
\text { ds }\end{array}$ & 2015 & $\begin{array}{l}\text { 3D CPC, CCPC and } \\
\text { hexagonal CPC made } \\
\text { by 3D printing }\end{array}$ & $\begin{array}{l}\text { Conceptual } \\
\text { design/Test } \\
\text { prototype }\end{array}$ & Test prototype & $\begin{array}{l}\text { 3D printing, } \\
\text { multiple area }\end{array}$ & none & 6,15 & NA \\
\hline & [49] & USA & 2010 & $\begin{array}{l}\text { 2D reflective } C P C, 2 D \\
\text { and } 3 D \text { dielectric filled } \\
C P C\end{array}$ & $\begin{array}{l}\text { Theoretical } \\
\text { analysis }\end{array}$ & $\begin{array}{l}\text { Design CPC geometry in } \\
\text { direction cosine space } \\
\text { on a polar plane }\end{array}$ & multiple area & none & NA & NA \\
\hline & [78] & UK & 2015 & $\begin{array}{l}\text { 2D } \text { dielectric filled } \\
\mathrm{CPC}\end{array}$ & $\begin{array}{l}\text { Theoretical } \\
\text { analysis }\end{array}$ & PHOTOPIA & multiple area & none & 4 & 22.02 \\
\hline & {$[52]$} & $\begin{array}{l}\text { Switzerlan } \\
\text { d }\end{array}$ & 2013 & $\begin{array}{l}\text { 3D CPC with } \\
\text { Polygonal apertures }\end{array}$ & $\begin{array}{l}\text { Theoretical } \\
\text { analysis }\end{array}$ & $\begin{array}{l}\text { Monte Carlo ray-tracing } \\
\text { by in-house VeGaS code }\end{array}$ & multiple area & none & NA & NA \\
\hline & [79] & USA & 2017 & 2D and 3D CPC & $\begin{array}{l}\text { Literature } \\
\text { review }\end{array}$ & NA & Multiple area & NA & NA & NA \\
\hline \multirow{4}{*}{$\begin{array}{l}\text { CPC in } \\
\text { PV }\end{array}$} & [82] & Malaysia & 2017 & 2D and 3D CPC & $\begin{array}{l}\text { Literature } \\
\text { review }\end{array}$ & NA & Multiple area & NA & NA & NA \\
\hline & [83] & Greece & 2017 & $\begin{array}{l}\text { 2D reflective trough } \\
\mathrm{CPC}\end{array}$ & $\begin{array}{l}\text { Conceptual } \\
\text { design/test } \\
\text { prototype } \\
\text { (outdoor) }\end{array}$ & $\begin{array}{l}\text { Ray-tracing simulation/ } \\
\text { Test prototype }\end{array}$ & PV/T system & $\begin{array}{l}\text { Two-axis } \\
\text { tracking }\end{array}$ & $\begin{array}{l}14.2- \\
113.4\end{array}$ & NA \\
\hline & {$[65]$} & China & 2010 & $\begin{array}{l}\text { 2D reflective trough } \\
\mathrm{CPC}\end{array}$ & $\begin{array}{l}\text { Test } \\
\text { prototype } \\
\text { (outdoor) }\end{array}$ & test prototype & $\begin{array}{l}\text { single-pass } \\
\text { PV/T system }\end{array}$ & none & NA & 30 \\
\hline & [53] & $\begin{array}{l}\text { Saudi } \\
\text { Arabia }\end{array}$ & 2013 & $\begin{array}{l}\text { 2D reflective trough } \\
\mathrm{CPC}\end{array}$ & $\begin{array}{l}\text { Conceptual } \\
\text { design }\end{array}$ & $\begin{array}{l}\text { Engineering Equation } \\
\text { Solver (EES) software }\end{array}$ & PV & one-axis & 2.3 & 41.75 \\
\hline
\end{tabular}




\begin{tabular}{|c|c|c|c|c|c|c|c|c|c|}
\hline [66] & $\begin{array}{l}\text { Saudi } \\
\text { Arabia }\end{array}$ & 2014 & $\begin{array}{l}\text { 2D reflective trough } \\
\mathrm{CPC}\end{array}$ & $\begin{array}{l}\text { Conceptual } \\
\text { design/test } \\
\text { prototype } \\
\text { (outdoor) }\end{array}$ & $\begin{array}{l}\text { Engineering Equation } \\
\text { Solver (EES) software }\end{array}$ & PV/T system & $\begin{array}{l}\text { seasonal tilt } \\
\text { adjustment }\end{array}$ & 2.3 & 41.75 \\
\hline [84] & Italy & 2012 & $\begin{array}{l}\text { 2D reflective CPC with } \\
\text { prism }\end{array}$ & $\begin{array}{l}\text { Conceptual } \\
\text { design/Test } \\
\text { prototype }\end{array}$ & ray tracing simulation & PV cell & none & 5 & 24 \\
\hline [59] & UK/China & 2012 & $\begin{array}{l}\text { Lens-walled CPC with } \\
\text { reflective coating } \\
\text { outside }\end{array}$ & $\begin{array}{l}\text { Conceptual } \\
\text { design }\end{array}$ & $\begin{array}{l}\text { Radiance/Pmap and } \\
\text { PHOTOPIA }\end{array}$ & PV & none & 4 & $\begin{array}{l}\text { The lens- } \\
\text { forming } \\
\text { angle is } 3\end{array}$ \\
\hline [60] & UK/China & 2012 & $\begin{array}{l}\text { Lens-walled CPC with } \\
\text { reflective coating } \\
\text { outside }\end{array}$ & $\begin{array}{l}\text { Conceptual } \\
\text { design }\end{array}$ & PHOTOPIA & PV & none & 2.5 & $\begin{array}{l}\text { The lens- } \\
\text { forming } \\
\text { angle is 3- } \\
5\end{array}$ \\
\hline [61] & China/UK & 2013 & $\begin{array}{l}\text { Lens-walled CPC with } \\
\text { reflective coating } \\
\text { outside }\end{array}$ & $\begin{array}{l}\text { Conceptual } \\
\text { design/Test } \\
\text { prototype }\end{array}$ & $\begin{array}{l}\text { SolidWorks for model } \\
\text { built, Light tools for ray } \\
\text { tracing }\end{array}$ & PV & none & 4 & $\begin{array}{l}\text { The lens- } \\
\text { forming } \\
\text { angle is } 3\end{array}$ \\
\hline [62] & China/UK & 2014 & $\begin{array}{l}\text { improved Lens-walled } \\
\text { CPC with air gap }\end{array}$ & $\begin{array}{l}\text { Conceptual } \\
\text { design/Test } \\
\text { prototype }\end{array}$ & LightTools & PV & none & 4 & $\begin{array}{l}\text { The lens- } \\
\text { forming } \\
\text { angle is } 3\end{array}$ \\
\hline [63] & China/UK & 2014 & $\begin{array}{l}\text { Lens-walled CPC with } \\
\text { air gap integrating } \\
\text { with PV/T system }\end{array}$ & $\begin{array}{l}\text { Conceptual } \\
\text { design/Test } \\
\text { prototype } \\
\text { (outdoor) }\end{array}$ & LightTools & $\mathrm{PV} / \mathrm{T}$ & none & 2.4 & $\begin{array}{l}\text { The lens- } \\
\text { forming } \\
\text { angle is } 5\end{array}$ \\
\hline [88] & China/UK & 2015 & $\begin{array}{l}\text { Lens-walled CPC with } \\
\text { air gap integrating } \\
\text { with PV/T system }\end{array}$ & $\begin{array}{l}\text { Conceptual } \\
\text { design/Test } \\
\text { prototype } \\
\text { (outdoor) }\end{array}$ & Ray tracing simulation & $\mathrm{PV} / \mathrm{T}$ & none & 4 & $\begin{array}{l}\text { The lens- } \\
\text { forming } \\
\text { angle is } 5\end{array}$ \\
\hline [89] & China/UK & 2015 & $\begin{array}{l}\text { Lens-walled CPC with } \\
\text { air gap integrating } \\
\text { with PV/T system }\end{array}$ & $\begin{array}{l}\text { Theoretical } \\
\text { analysis/Test } \\
\text { prototype }\end{array}$ & CFD/Test prototype & $\mathrm{PV} / \mathrm{T}$ & none & 4 & $\begin{array}{l}\text { The lens- } \\
\text { forming } \\
\text { angle is } 5\end{array}$ \\
\hline
\end{tabular}




\begin{tabular}{|c|c|c|c|c|c|c|c|c|c|}
\hline & & & & (outdoor) & & & & & \\
\hline [90] & UK & 2013 & reflective CСРC & $\begin{array}{l}\text { conceptual } \\
\text { design/test } \\
\text { prototype }\end{array}$ & Ray tracing by MATLAB & PV & none & 3.6 & 30 \\
\hline [92] & UK & 2015 & reflective, CCPC & $\begin{array}{l}\text { conceptual } \\
\text { design }\end{array}$ & $\begin{array}{l}\text { multiphysics model and } \\
\text { ANSYS CFX } 15.0\end{array}$ & PV & none & 3.6 & 20 \\
\hline [71] & UK/Spain & 2014 & dielectric filled CCPC & $\begin{array}{l}\text { conceptual } \\
\text { design/test } \\
\text { prototype }\end{array}$ & OptisWorks & PV & none & 3.6 & 48.5 \\
\hline$[76]$ & UK & 2015 & dielectric filled CCPC & $\begin{array}{l}\text { conceptual } \\
\text { design/test } \\
\text { prototype }\end{array}$ & APEX & PV & none & 3.6 & 48.5 \\
\hline [93] & China/UK & 2012 & $\begin{array}{l}\text { 2D dielectric filled } \\
\text { trough } \mathrm{CPC}\end{array}$ & $\begin{array}{l}\text { Conceptual } \\
\text { design/Test } \\
\text { prototype }\end{array}$ & LightTools & PV & none & 2.41 & 36.8 \\
\hline [94] & Spain/UK & 2015 & $\begin{array}{l}\text { 2D dielectric filled } \\
\text { CPC }\end{array}$ & $\begin{array}{l}\text { Conceptual } \\
\text { design/Test } \\
\text { prototype }\end{array}$ & Life cycle assessment & PV & none & 2.8 & 55 \\
\hline [96] & Malaysia & 2017 & $\begin{array}{l}\text { CPC incorporates with } \\
\text { dish concentrator }\end{array}$ & $\begin{array}{l}\text { Literature } \\
\text { review }\end{array}$ & NA & PV & NA & NA & NA \\
\hline [95] & Malaysia & 2015 & $\begin{array}{l}\text { dielectric filled CCPC } \\
\text { incorporates with dish } \\
\text { concentrator }\end{array}$ & $\begin{array}{l}\text { Conceptual } \\
\text { design }\end{array}$ & $\begin{array}{l}\text { LightTools for flux } \\
\text { distribution, Simulink } \\
\text { for electricity } \\
\text { generation }\end{array}$ & PV & two-axis & 6.0 & 24.1 \\
\hline [73] & $\begin{array}{l}\text { UK/Germa } \\
\text { ny/Switzer } \\
\text { land }\end{array}$ & 2015 & $\begin{array}{l}\text { dielectric filled, } 3 D \\
\text { revolved CPC }\end{array}$ & $\begin{array}{l}\text { Conceptual } \\
\text { design }\end{array}$ & $\begin{array}{l}\text { Monte Carlo } \\
\text { simulations by } \\
\text { Optisworks }\end{array}$ & $\begin{array}{l}\text { up-conversion } \\
\text { solar cells }\end{array}$ & none & 2.8 & 25 or 45 \\
\hline
\end{tabular}




\begin{tabular}{|c|c|c|c|c|c|c|c|c|c|c|}
\hline & [97] & Russia & 1994 & $\begin{array}{l}\text { 2D reflective CPC with } \\
\text { convex lens }\end{array}$ & $\begin{array}{l}\text { Conceptual } \\
\text { design/Test } \\
\text { prototype }\end{array}$ & $\begin{array}{l}\text { ray tracing, didn't know } \\
\text { software }\end{array}$ & $\begin{array}{l}\text { PV cell } \\
\text { (AlGaAs-GaAs } \\
\text { heterostructur } \\
\text { e) }\end{array}$ & one-axis & 21 & NA \\
\hline & [98] & $\begin{array}{l}\text { Taiwan, } \\
\text { China }\end{array}$ & 2013 & $\begin{array}{l}\text { reflective, variable- } \\
\text { focus-parabolic (VFP) } \\
\text { reflector with circular } \\
\text { and square focus spot }\end{array}$ & $\begin{array}{l}\text { Conceptual } \\
\text { design }\end{array}$ & $\begin{array}{l}\text { Analytical model, skew- } \\
\text { ray tracing by ZEMAX }\end{array}$ & PV & none & NA & NA \\
\hline & [99] & $\begin{array}{l}\text { UK/Malay } \\
\text { sia }\end{array}$ & 2014 & $\begin{array}{l}\text { reflective, rotationally } \\
\text { asymmetrical CPC } \\
(\mathrm{RACPC})\end{array}$ & $\begin{array}{l}\text { Conceptual } \\
\text { design }\end{array}$ & Matlab, ZEMAX & PV & none & 3.7 & 42 \\
\hline & [100] & $\begin{array}{l}\text { UK/Malay } \\
\text { sia }\end{array}$ & 2015 & $\begin{array}{l}\text { reflective, rotationally } \\
\text { asymmetrical CPC } \\
(\mathrm{RACPC})\end{array}$ & $\begin{array}{l}\text { test } \\
\text { prototype }\end{array}$ & test prototype & PV & none & 3.7 & 42 \\
\hline \multirow{6}{*}{$\begin{array}{l}\text { CPC in } \\
\text { solar } \\
\text { thermal } \\
\text { or } \\
\text { hybrid }\end{array}$} & [101] & Mexico & 2017 & 2D Reflective CPC & $\begin{array}{l}\text { Conceptual } \\
\text { design/Test } \\
\text { prototype } \\
\text { (outdoor) }\end{array}$ & $\begin{array}{l}\text { Numerical } \\
\text { computation/ Test } \\
\text { prototype }\end{array}$ & Solar thermal & none & 1.8 & 15 \\
\hline & [102] & USA & 2009 & $\begin{array}{l}\text { 2D reflective CPC with } \\
\text { absorber }\end{array}$ & $\begin{array}{l}\text { Conceptual } \\
\text { design }\end{array}$ & Simulink, Matlab & solar thermal & none & NA & NA \\
\hline & [103] & Jordan & 2013 & $\begin{array}{l}\text { 2D reflective trough } \\
\mathrm{CPC} \text { with flat absorber }\end{array}$ & $\begin{array}{l}\text { Test } \\
\text { prototype } \\
\text { (outdoor) }\end{array}$ & $\begin{array}{l}\text { MATLAB for optimizing } \\
\text { the minimum CPC } \\
\text { height }\end{array}$ & Solar thermal & one-axis & 2.5 & 28 \\
\hline & [105] & $\begin{array}{l}\text { Thailand/ } \\
\text { Germany }\end{array}$ & 2014 & $\begin{array}{l}\text { 2D reflective CPC with } \\
\text { absorber }\end{array}$ & $\begin{array}{l}\text { Conceptual } \\
\text { design }\end{array}$ & Ray tracing simulation & solar thermal & none & NA & $63.5,40$ \\
\hline & [106] & Thailand & 2015 & $\begin{array}{l}\text { 2D reflective CPC with } \\
\text { absorber }\end{array}$ & $\begin{array}{l}\text { Operational } \\
\text { prototype } \\
\text { (outdoor) }\end{array}$ & Operational prototype & solar thermal & none & NA & NA \\
\hline & [104] & India & 2017 & $\begin{array}{l}\text { 2D reflective } \mathrm{CPC} \\
\text { integrated with U- } \\
\text { shape ETC }\end{array}$ & $\begin{array}{l}\text { Test } \\
\text { prototype } \\
\text { (outdoor) }\end{array}$ & Test prototype & solar thermal & none & NA & NA \\
\hline
\end{tabular}




\begin{tabular}{|c|c|c|c|c|c|c|c|c|c|}
\hline $\begin{array}{l}{[107,} \\
108]\end{array}$ & UK & $\begin{array}{l}2014 \\
2015\end{array}$ & $\begin{array}{l}\text { 2D reflective CPC with } \\
\text { absorber }\end{array}$ & $\begin{array}{l}\text { Conceptual } \\
\text { design }\end{array}$ & $\begin{array}{l}\text { Ray tracing by } \\
\text { OptisWorks }\end{array}$ & solar thermal & none & NA & $30,40,60$ \\
\hline [109] & China/UK & 2012 & $\begin{array}{l}\text { 2D reflective CPC with } \\
\text { absorber }\end{array}$ & $\begin{array}{l}\text { Test } \\
\text { prototype }\end{array}$ & Test prototype & Solar thermal & none & NA & NA \\
\hline [110] & China/UK & 2017 & $\begin{array}{l}\text { 2D reflective CPC with } \\
\text { pulsating heat pipe }\end{array}$ & $\begin{array}{l}\text { Test } \\
\text { prototype } \\
\text { (outdoor) }\end{array}$ & Test prototype & Solar thermal & none & 3.4 & NA \\
\hline [111] & China & 2015 & $\begin{array}{l}\text { 2D reflective CPC with } \\
\text { absorber }\end{array}$ & $\begin{array}{l}\text { Conceptual } \\
\text { design/Test } \\
\text { prototype } \\
\text { (outdoor) }\end{array}$ & TracePro & Solar thermal & $\begin{array}{l}\text { Two-axis } \\
\text { tracking } \\
\text { mechanism }\end{array}$ & 2.3 & 23.5 \\
\hline [112] & USA & 2013 & $\begin{array}{l}\text { 2D CPC with tubular, } \\
\text { coupled } \quad \text { with } \\
\text { wavelength selective } \\
\text { film }\end{array}$ & $\begin{array}{l}\text { Conceptual } \\
\text { design }\end{array}$ & Monte Carlo ray tracing & $\begin{array}{l}\text { PV and solar } \\
\text { thermal }\end{array}$ & none & $1.2-2$ & $45-87$ \\
\hline [113] & China & 2011 & $\begin{array}{l}\text { 2D reflective CPC with } \\
\text { tubular, integrated } \\
\text { with reflective } \\
\text { Fresnel lens }\end{array}$ & $\begin{array}{l}\text { Conceptual } \\
\text { design }\end{array}$ & CFD & Solar thermal & none & 25 & NA \\
\hline [114] & India & 2017 & $\begin{array}{ll}2 \mathrm{D} \text { reflective } & \mathrm{CPC}, \\
\text { integrated } & \text { with } \\
\text { Fresnel lens } & \\
\end{array}$ & $\begin{array}{l}\text { Conceptual } \\
\text { design/Test } \\
\text { prototype } \\
\text { (outdoor) }\end{array}$ & $\begin{array}{l}\text { Advanced Systems } \\
\text { Analysis Program }\end{array}$ & Solar thermal & none & 58 & NA \\
\hline [115] & Malaysia & 2017 & $\begin{array}{ll}2 \mathrm{D} \text { reflective } & \mathrm{CPC}, \\
\text { integrated } & \text { with } \\
\text { Fresnel lens } & \\
\end{array}$ & $\begin{array}{l}\text { Conceptual } \\
\text { design }\end{array}$ & $\begin{array}{l}\text { Numerical computation } \\
\text { by MATLAB }\end{array}$ & Solar thermal & none & 1.78 & NA \\
\hline [116] & China & 2017 & $\begin{array}{l}\text { 2D CPC integrated } \\
\text { with Fresnel lens }\end{array}$ & $\begin{array}{l}\text { Conceptual } \\
\text { design/Test } \\
\text { prototype }\end{array}$ & $\begin{array}{l}\text { Test prototype } \\
\text { (outdoor) }\end{array}$ & Solar thermal & $\begin{array}{l}\text { One-axis } \\
\text { tracking }\end{array}$ & 10 & 40.5 \\
\hline [117] & $\begin{array}{l}\text { UK/Irelan } \\
\text { d }\end{array}$ & 2005 & $2 \mathrm{D}$ reflective $\mathrm{CPC}$ & $\begin{array}{l}\text { Conceptual } \\
\text { design/Test }\end{array}$ & Test prototype & $\begin{array}{l}\text { Solar thermal } \\
\text { water heaters }\end{array}$ & none & 1.84 & 30 \\
\hline
\end{tabular}




\begin{tabular}{|c|c|c|c|c|c|c|c|c|c|c|}
\hline & & & & & prototype & & & & & \\
\hline & [118] & Italy & 2015 & $\begin{array}{l}\text { 2D reflective CPC with } \\
\text { absorber }\end{array}$ & $\begin{array}{l}\text { Conceptual } \\
\text { design }\end{array}$ & AMESim & Solar thermal & none & 1.1-1.4 & NA \\
\hline & [119] & India & 2017 & $\begin{array}{l}\text { 2D reflective } \mathrm{CPC} \text { with } \\
\text { absorber }\end{array}$ & $\begin{array}{l}\text { Conceptual } \\
\text { design }\end{array}$ & $\begin{array}{l}\text { Numerical computation } \\
\text { by MATLAB }\end{array}$ & Solar thermal & none & NA & NA \\
\hline & $\begin{array}{l}120, \\
121]\end{array}$ & India & 2017 & $\begin{array}{l}\text { 2D reflective trough } \\
\mathrm{CPC}\end{array}$ & $\begin{array}{l}\text { Conceptual } \\
\text { design }\end{array}$ & $\begin{array}{l}\text { Numerical computation } \\
\text { by MATLAB }\end{array}$ & $\begin{array}{l}\text { Solar } \\
\text { distillation }\end{array}$ & none & NA & NA \\
\hline & [122] & Japan & 2013 & $3 \mathrm{D}$ reflective $\mathrm{CPC}$ & $\begin{array}{l}\text { Conceptual } \\
\text { design/Test } \\
\text { prototype } \\
\text { (outdoor) }\end{array}$ & $\begin{array}{l}\text { ray tracing, didn't know } \\
\text { software }\end{array}$ & $\begin{array}{l}\text { water steam } \\
\text { generating }\end{array}$ & none & NA & 30 \\
\hline & [123] & $\begin{array}{l}\text { Saudi } \\
\text { Arabia/ } \\
\text { Egypt }\end{array}$ & 2017 & $\begin{array}{l}\text { 2D reflective trough } \\
\mathrm{CPC}\end{array}$ & $\begin{array}{l}\text { Test } \\
\text { prototype } \\
\text { (outdoor) }\end{array}$ & Test prototype & $\begin{array}{l}\text { Solar } \\
\text { distillation }\end{array}$ & $\begin{array}{l}\text { Manually } \\
\text { one-axis } \\
\text { tracking }\end{array}$ & NA & NA \\
\hline \multirow{4}{*}{$\begin{array}{l}\text { CPC in } \\
\text { daylighti } \\
\text { ng or } \\
\text { hybrid }\end{array}$} & [70] & Germany & 2005 & $\begin{array}{l}\text { Microstructure } 2 \mathrm{D} \\
\text { trough CPC with } \\
\text { facet-selective coating }\end{array}$ & $\begin{array}{l}\text { Conceptual } \\
\text { design/Test } \\
\text { prototype } \\
\text { (outdoor) }\end{array}$ & test prototype & $\begin{array}{l}\text { microstructure, } \\
\text { daylighting } \\
\text { control }\end{array}$ & none & NA & NA \\
\hline & [125] & UK/China & 2014 & $\begin{array}{l}\text { 2D dielectric filled } \\
\text { CPC }\end{array}$ & $\begin{array}{l}\text { Conceptual } \\
\text { design/Test } \\
\text { prototype } \\
\text { (outdoor) }\end{array}$ & PHOTOPIA & $\begin{array}{l}\text { PV /daylighting } \\
\text { control }\end{array}$ & none & 3.6 & 22.05 \\
\hline & $\begin{array}{l}{[126,} \\
127]\end{array}$ & USA & 2014 & $\begin{array}{l}\text { 2D dielectric CPC with } \\
\text { tubular absorber }\end{array}$ & $\begin{array}{l}\text { Conceptual } \\
\text { design }\end{array}$ & Monte Carlo ray tracing & $\begin{array}{l}\text { Tubular } \\
\text { absorber and } \\
\text { daylighting }\end{array}$ & none & $1.5-2.3$ & $25-45$ \\
\hline & [128] & UK & 2000 & $\begin{array}{l}\text { 2D dielectric filled } \\
\text { symmetric CPC and } \\
\text { asymmetric CPC }\end{array}$ & $\begin{array}{l}\text { Conceptual } \\
\text { design }\end{array}$ & $\begin{array}{l}\text { Ray tracing based on } \\
\text { the criterion of total } \\
\text { internal reflection }\end{array}$ & $\begin{array}{l}\text { PV/building } \\
\text { facade }\end{array}$ & none & $\begin{array}{l}2.46 \\
2.96\end{array}$ & $37,36.4$ \\
\hline
\end{tabular}




\begin{tabular}{|c|c|c|c|c|c|c|c|c|c|}
\hline $\begin{array}{l}{[67,} \\
129]\end{array}$ & $\begin{array}{l}\text { UK/Irelan } \\
\text { d }\end{array}$ & 2006 & $\begin{array}{l}\text { 2D reflective } \\
\text { asymmetric CPC }\end{array}$ & $\begin{array}{l}\text { Test } \\
\text { prototype } \\
\text { (outdoor) }\end{array}$ & test prototype & $\begin{array}{l}\text { PV cell/building } \\
\text { facade }\end{array}$ & none & 2.0 & 50 and 0 \\
\hline [69] & UK & 2007 & $\begin{array}{l}\text { 2D reflective } \\
\text { asymmetric } \mathrm{CPC}\end{array}$ & $\begin{array}{l}\text { Test } \\
\text { prototype } \\
\text { (outdoor) }\end{array}$ & test prototype & $\begin{array}{l}\text { PV cell/building } \\
\text { facade }\end{array}$ & none & 2.45 & 37 and 0 \\
\hline [130] & UK & 2015 & $\begin{array}{l}\text { 2D dielectric filled } \\
\text { asymmetric CPC }\end{array}$ & $\begin{array}{l}\text { Test } \\
\text { prototype } \\
\text { (outdoor) }\end{array}$ & $\begin{array}{l}\text { test prototype, outdoor } \\
\text { experiment }\end{array}$ & $\begin{array}{l}\text { PV cell/building } \\
\text { facade }\end{array}$ & none & 2.8 & 0 and 55 \\
\hline [72] & UK/Spain & 2014 & $\begin{array}{l}\text { 2D dielectric filled } \\
\text { trough } \mathrm{CPC}\end{array}$ & $\begin{array}{l}\text { Conceptual } \\
\text { design/test } \\
\text { prototype }\end{array}$ & $\begin{array}{l}\text { COMSOL Multiphysics } \\
\text { software }\end{array}$ & $\begin{array}{l}\text { PV cell/building } \\
\text { facade }\end{array}$ & none & 2.8 & 55 \\
\hline$[74]$ & UK & 2014 & $\begin{array}{l}\text { 2D dielectric filled } \\
\text { asymmetric CPC }\end{array}$ & $\begin{array}{l}\text { Conceptual } \\
\text { design/Test } \\
\text { prototype }\end{array}$ & $\begin{array}{l}\text { Ray tracing, indoor } \\
\text { experiment }\end{array}$ & $\begin{array}{l}\text { PV cell/building } \\
\text { facade }\end{array}$ & none & 2.8 & 0 and 55 \\
\hline [131] & Thailand & 2014 & $3 \mathrm{D}$ reflective $\mathrm{CPC}$ & $\begin{array}{l}\text { Conceptual } \\
\text { design/Test } \\
\text { prototype } \\
\text { (outdoor) }\end{array}$ & Matlab & $\begin{array}{l}\text { roof mounted } \\
\text { light pipe }\end{array}$ & none & 2.42 & 40 \\
\hline [132] & $\begin{array}{l}\text { Singapore } \\
\text { /Switzerla } \\
\text { nd }\end{array}$ & 2010 & $3 \mathrm{D}$ reflective $\mathrm{CPC}$ & $\begin{array}{l}\text { Conceptual } \\
\text { design }\end{array}$ & $\begin{array}{l}\text { Ray tracing by } \\
\text { PHOTOPIA }\end{array}$ & $\begin{array}{l}\text { anidolic } \\
\text { daylighting } \\
\text { system } \\
\end{array}$ & none & NA & NA \\
\hline [68] & Japan & 1997 & $3 \mathrm{D}$ reflective $\mathrm{CPC}$ & $\begin{array}{l}\text { Conceptual } \\
\text { design/Test } \\
\text { prototype } \\
\text { (outdoor) }\end{array}$ & NA & $\begin{array}{l}\text { concentrate } \\
\text { light exiting } \\
\text { from optical } \\
\text { fibre }\end{array}$ & Two-axis & $3.6-4.4$ & 26 \\
\hline [133] & China/UK & 2011 & $3 \mathrm{D}$ reflective $\mathrm{CPC}$ & $\begin{array}{l}\text { Conceptual } \\
\text { design/Test } \\
\text { prototype }\end{array}$ & $\begin{array}{l}\text { Ray tracing by } \\
\text { LightTools }\end{array}$ & $\begin{array}{l}\text { solar optical } \\
\text { fibre system }\end{array}$ & $\begin{array}{l}\text { two-axis } \\
\text { tracking }\end{array}$ & 278 & 3.4 \\
\hline
\end{tabular}




\begin{tabular}{|c|c|c|c|c|c|c|c|c|c|c|}
\hline & & & & & (outdoor) & & & & & \\
\hline & [134] & $\begin{array}{l}\text { South } \\
\text { Korea }\end{array}$ & 2014 & $\begin{array}{l}\text { 2D reflective trough } \\
\mathrm{CPC}\end{array}$ & $\begin{array}{l}\text { Conceptual } \\
\text { design }\end{array}$ & $\begin{array}{l}\text { LightTools and } \\
\text { SolidWorks, DIALux for } \\
\text { interior lighting }\end{array}$ & $\begin{array}{l}\text { optical fibre } \\
\text { daylighting } \\
\text { system }\end{array}$ & none & NA & NA \\
\hline \multirow{8}{*}{$\begin{array}{l}\text { CPC in } \\
\text { other } \\
\text { areas }\end{array}$} & [136] & Turkey & 2013 & $\begin{array}{l}\text { 2D reflective trough } \\
\mathrm{CPC}\end{array}$ & $\begin{array}{l}\text { Literature } \\
\text { review }\end{array}$ & NA & $\begin{array}{l}\text { Water } \\
\text { degradation }\end{array}$ & none & NA & NA \\
\hline & [29] & Japan & 2013 & $\begin{array}{l}\text { 3D CPC with an extra } \\
\text { cavity }\end{array}$ & $\begin{array}{l}\text { Conceptual } \\
\text { design/ Test } \\
\text { prototype }\end{array}$ & ZEMAX & $\begin{array}{l}\text { Terahertz } \\
\text { technology }\end{array}$ & none & 100 & 5.5 \\
\hline & [30] & USA & 2014 & $3 \mathrm{D}$ reflective $\mathrm{CPC}$ & $\begin{array}{l}\text { Conceptual } \\
\text { design/Test } \\
\text { prototype }\end{array}$ & $\begin{array}{l}\text { ray tracing, didn't know } \\
\text { software }\end{array}$ & $\begin{array}{l}\text { Overmoded } \\
\text { waveguide }\end{array}$ & none & 6.3 or 64 & NA \\
\hline & {$[22]$} & Japan & 2002 & $3 \mathrm{D}$ reflective $\mathrm{CPC}$ & $\begin{array}{l}\text { Conceptual } \\
\text { design/Test } \\
\text { prototype }\end{array}$ & OptiCAD & $\begin{array}{l}\text { p-i-n } \\
\text { photodiode }\end{array}$ & none & NA & $\begin{array}{l}\text { Maximum } \\
\text { emitting } \\
\text { angle from } \\
\text { GI-POF is } \\
15.6\end{array}$ \\
\hline & {$[23]$} & Portugal & 2007 & $\begin{array}{l}\text { 2D reflective CPC with } \\
\text { elliptical cavity or CPC } \\
\text { cavity }\end{array}$ & $\begin{array}{l}\text { Conceptual } \\
\text { design }\end{array}$ & ZEMAX & Diode pumping & none & NA & 56 \\
\hline & [24] & $\begin{array}{l}\text { Portugal/F } \\
\text { rance }\end{array}$ & 2007 & $\begin{array}{l}2 \mathrm{D} \text { reflective } \mathrm{CPC} \text { as } \\
\text { pump cavity }\end{array}$ & $\begin{array}{l}\text { Conceptual } \\
\text { design }\end{array}$ & ZEMAX & $\begin{array}{l}\text { solar-pumped } \\
\text { laser }\end{array}$ & none & NA & NA \\
\hline & {$[26]$} & China & 2010 & 3D dielectric CCPC & $\begin{array}{l}\text { Conceptual } \\
\text { design/Test } \\
\text { prototype }\end{array}$ & ray tracing simulation & LED projector & none & 2.25 & 12 \\
\hline & {$[25]$} & HongKong & 2007 & 3D dielectric CCPC & $\begin{array}{l}\text { Conceptual } \\
\text { design/Test } \\
\text { prototype }\end{array}$ & ray tracing simulation & LED projector & none & NA & NA \\
\hline
\end{tabular}

